Інститут держави і права ім. В.М. Корецького НАН України Інститут законодавчих передбачень і правової експертизи

\title{
СОLுІО^ОГІЯ ПРАВА
}

науково-практичний журнал

Випуск 1 (32)

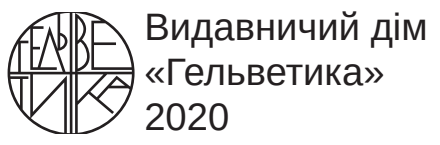


РЕДАКЩІЙНА РАДА:

Безлюдний О.I., доктор педагогічних наук, професор, ректор Уманського державного педагогічного університету імені Павла Тичини; Гетьман А.П., академік Національної академії правових наук України, доктор юридичних наук, професор, проректор 3 наукової роботи Національного юридичного університету імені Ярослава Мудрого (заступник Голови Редакційної ради);

Горбань А.В., Голова Вченої ради Державного університету інфраструктури і технологій, кандидат історични наук, доцент, перший проректор Державного університету інфраструктури і технологій (І заступник Голова Редакційної ради);

Гриценко I.C., доктор юридичних наук, професор, декан юридичного факультету Київського національного університету імені Тараса Шевченка;

Карольчак Казимир, доктор наук, професор, ректор педагогічного університету імені Комісії народної освіти в Кракові (Польща);

Костицький В.В., академік Національної академії правових наук України, доктор юридичних наук, професор, професор кафедри теорії права і держави Київського національного університету імені Тараса Шевченка, президент Асоціації українських правників, голова Вченої ради Інституту законодавчих передбачень і правової експертизи (головний редактор);

Оніщенко Н.М., академік Національної академії правових наук України, доктор юридичних наук, професор, I віце-президент Асоціації українських правників;

Фоменко А.С., кандидат юридичних наук, ректор Дніпропетровського державного університету внутрішніх справ;

Сопільник Л.І., доктор юридичних наук, доктор технічних наук, професор;

Шемшученко Ю.С., академік Національної академії наук України та Національної академії правових наук України, доктор юридичних наук, професор, директор Інституту держави і права Національної академії правових наук України імені Володимира Корецького (Голова Редакційної ради)

\section{РЕДАКЦІЙНА КОЛЕГІЯ}

Наливайко Л.Р., доктор юридичних наук, професор, проректор Дніпропетровського державного університету внутрішніх справ, віце-президент Асоціації українських правників (головний редактор);

Костицький В.В., академік Національної академії правових наук України, доктор юридичних наук, професор (відповідальний редактор);

Новицька Н.Б., доктор юридичних наук, старший науковий співробітник (заступник головного редактора).

Члени редколегії:

Бєлов Д.М., доктор юридичних наук, професор; Бобровник С.В., доктор юридичних наук, професор; Бондар О.Г., доктор юридичних наук, доцент; Вереша Р.В., доктор юридичних наук, професор; Волошин Ю.О., доктор юридичних наук, професор; Дідич Т.О., доктор юридичних наук, доцент; Срмоленко В.М., доктор юридичних наук, професор; Захарченко П.П., доктор юридичних наук, професор; Костицька I.O., кандидат юридичних наук, старший науковий співробітник; Кушнір С.М., доктор юридичних наук, доцент; Сидор В.Д., доктор юридичних наук, професор; Стефанчук М.О., кандидат юридичних наук, доцент; Тильчик В.В., кандидат юридичних наук, доцент; Харитонова Т.Є., доктор юридичних наук, доцент; Гжегож Кравець, доктор юридичних наук, професор (Республіка Польща); Бернгард Шлоер, доктор юридичних наук, професор (ФРН-Україна).

Редакція англомовних текстів - С. Костицька

Редакція журналу не завжди поділяє позиції авторів з приводу висловлюваних проблем

і не несе відповідальності за зміст авторських публікацій.

Журнал рекомендовано до друку Рішенням Вченої ради Інституту законодавчих передбачень і правової експертизи (протокол № 2 від 23.02.2020 р.).

На підставі Наказу Міністерства освіти і науки України № 886 від 02.07.2020 р. (додаток 4) журнал включено до Переліку наукових фахових видань України категорії «Б» у галузі юридичних наук (081 «Право»). Журнал заресстрований Міністерством юстиції України

(Свідоцтво про державну ресстрацію серії КВ № 20487-10287 ПР від 24.12.2013).

Інститут законодавчих передбачень і правової експертизи

01034, м. Київ, вул. Паторжинського, 4, оф. 8, тел./факс 278-50-12 
ISSN 2413-6433

V.M. KORETSKY INSTITUTE OF STATE AND LAW OF THE NAS OF UKRAINE INSTITUTE OF LEGISLATIVE PREDICTIONS AND LEGAL EXPERTISE

\section{SOCIOLOGY OF LAW}

scientific and practical journal

Issue 1 (32)

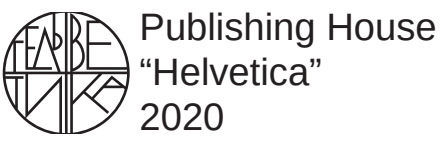




\section{EDITORIAL COUNCIL:}

Bezliudnyi O.I., Doctor of Pedagogy, Professor, Rector of Pavlo Tychyna Uman State Pedagogical University;

Hetman A.P., Academician of the National Academy of Legal Sciences of Ukraine, Doctor of Law, Professor, Vice Rector for Scientific Affairs of the Yaroslav Mudryi National Law University (Deputy Head of the Editorial Council);

Horban A.V., Head of the Academic Council of the State University of Infrastructure and Technologies, PhD in History, Associate Professor, First Vice Rector of the State University of Infrastructure and Technologies (I Deputy Head of the Editorial Council);

Hrytsenko I.S., Doctor of Law, Professor, Dean of the Faculty of Law of Taras Shevchenko National University of Kyiv;

Karolchak Kazymyr, Dr. habil., Professor, Rector of Pedagogical University of Cracow (Poland);

Kostytsky V., Academician of the National Academy of Legal Sciences of Ukraine, Doctor of Law, Professor, Professor at the Department of Theory of Law and State of Taras Shevchenko National University of Kyiv, President of Ukrainian Bar Association, Head of the Academic Council of the Institute of Legislative Predictions and Legal Expertise (Editor-in-Chief);

Onishchenko N.M., Academician of the National Academy of Legal Sciences of Ukraine, Doctor of Law, Professor, I Vice President of Ukrainian Bar Association;

Fomenko A.Ie., PhD in Law, Rector of Dnipropetrovsk State University of Internal Affairs;

Sopilnyk L.I., Doctor of Law, Doctor of Engineering, Professor;

Shemshuchenko Yu.S., Academician of the National Academy of Sciences of Ukraine and National Academy of Legal Sciences of Ukraine, Doctor of Law, Professor, Director of Volodymyr Koretskyi Institute of State and Law of the National Academy of Legal Sciences of Ukraine (Head of the Editorial Council)

\section{EDITORIAL BOARD:}

Nalyvaiko L.R., Doctor of Law, Professor, Vice Rector of Dnipropetrovsk State University of Internal Affairs, Vice President of Ukrainian Bar Association (Editor-in-Chief);

Kostytsky V., Academician of the National Academy of Legal Sciences of Ukraine, Doctor of Law, Professor (Executive Editor);

Novytska N.B., Doctor of Law, Senior Scientific Associate (Deputy Editor-in-Chief).

EDITORIAL BOARD MEMBERS:

Bielov D.M., Doctor of Law, Professor; Bobrovnyk S.V., Doctor of Law, Professor; Bondar O.H., Doctor of Law, Associate Professor; Veresha R.V., Doctor of Law, Professor; Voloshyn Yu.O., Doctor of Law, Professor; Didych T.O., Doctor of Law, Associate Professor; Yermolenko V.M., Doctor of Law, Professor; Zakharchenko P.P., Doctor of Law, Professor; Kostytska I.O., PhD in Law, Senior Research Fellow; Kushnir S.M., Doctor of Law, Associate Professor; Sydor V.D., Doctor of Law, Professor; Stefanchuk M.O., Candidate of Law, Associate Professor; Tylchyk V.V., PhD in Law, Associate Professor; Kharytonova T.Ie., Doctor of Law, Associate Professor; Grzegorz Krawiec, Doctor of Law, Professor (Poland); Bernhard Schloer, Doctor of Law, Professor (FRG-Ukraine).

Proofreading of English manuscripts - S. Kostytska

The Editorial Board may not share the authors' opinion and assumes no responsibility for the content of manuscripts.

The journal is recommended for printing by the Academic Council of the Institute of Legislative Predictions and Legal Expertise (Minutes № 2 dated February 23, 2020).

Based on the Order of the Ministry of Education and Science of Ukraine No. 886 of 02.07.2020 (Annex 4) the journal is included in the List of scientific professional publications of Ukraine of category "B" in the field of legal sciences (081 "Law").

The journal is registered by the Ministry of Justice of Ukraine

(Certificate of state registration of the KV series № 20487-10287 PR dated 24.12.2013).

Institute of Legislative Predictions and Legal Expertise 01034, Kyiv, 4, Patorzhynskoho St., office 8, phone/fax 278-50-12 


\section{MICT}

Курбатова I.C.

ЩОДО ЗАБЕЗПЕЧЕННЯ ПРОКУРОРОМ ПРАВ ОСОБИ

ПІД ЧАС ДОСУДОВОГО РОЗСЛІДУВАННЯ

Білько О.П.

КРИМІНОГЕННА СИТУАЦІЯ В УКРАЇНІ ТА ІІЇ ВПЛИВ

НА КРЕДИТНО-ФІНАНСОВУ ДІЯЛЬНІСТЬ БАНКІВСЬКИХ УСТАНОВ

Вітер Д.В.

ОКРЕМІ НАПРЯМИ ВДОСКОНАЛЕННЯ ВИКОРИСТАННЯ

СУДОВИХ ЕКСПЕРТИЗ ПІД ЧАС РОЗСЛІДУВАННЯ ЗЛОЧИНІВ

У СФЕРІ ФІНАНСУВАННЯ СОЦАЛЬНИХ ЦІЛЬОВИХ ПРОГРАМ

Гуйван П.Д.

ОСОБЛИВОСТІ СОЦІАЛЬНОГО ПРОЯВУ ЧАСУ

ПІД ЧАС ЙОГО ВИКОРИСТАННЯ В РЕГУЛЮВАННІ ПРАВОВІДНОСИН

Деркач I.M., Дяченко С.В.

ЗВЕРНЕННЯ СТЯГНЕННЯ НА МАЙНО, ПЕРЕДАНЕ В ІПОТЕКУ

Костицький В.В.

СОЦІОЛОГО-ПРАВОВА ЗУМОВЛЕНІСТЬ ПЛЮРАЛІСТИЧНОСТІ

СУЧАСНОГО ПРАВОРОЗУМІННЯ

Ларченко М.О.

МОДЕЛЮВАННЯ КІЛЬКІСНИХ ПОКАЗНИКІВ ЗЛОЧИННОСТІ ЗА ДОПОМОГОЮ

АЛГОРИТМІВ КЛАСТЕРНОГО ТА КАНОНІЧНОГО АНАЛІЗУ

Мельник Я.Я.

БЕЗПЕКА ТЕКСТОВОЇ ІДЕОЛОГІЇ СОЦІАЛЬНОГО ПРАВА:

АНТРОПОЛОГО-КОМУНІКАТИВНИЙ АСПЕКТ.

Новицька Н.Б., Таранюк Т.О.

ОСОБЛИВОСТІ ПРАВОВОГО РЕГУЛЮВАННЯ ПРАВА ІНТЕЛЕКТУАЛЬНОЇ ВЛАСНОСТІ НА ТВІР, СТВОРЕНИЙ У ПРОЦЕСІ ВИКОНАННЯ ТРУДОВОГО ДОГОВОРУ

Петрова І.А., Силенок К.П., Чекін Д.О.

МЕДІАЦІЯ ЯК ФОРМА ВИКОРИСТАННЯ СПЕЦІАЛЬНИХ ЗНАНЬ

У ЦИВІЛЬНОМУ ТА ГОСПОДАРСЬКОМУ ПРОЦЕСІ.

Салманова К.В., Дяченко С.В.

ПРАВО ФІЗИЧНОЇ ОСОБИ НА ДОНОРСТВО

ЯК ОСОБИСТЕ НЕМАЙНОВЕ ПРАВО. СУДОВИЙ ЗАХИСТ

Спссівцев Д.С.

ОХОРОННІ ВЛАСТИВОСТІ ТЕХНІЧНОЇ ІНВЕНТАРИЗАЦІЇ ОБ'ЄКТІВ НЕРУХОМОГО МАЙНА,

РОЗТАШОВАНИХ НА ЗЕМЕЛЬНІЙ ДІЛЯНЦІ.

Тимошенко М.O.

ДО ПИТАННЯ ПРО СОЦІОЛОГО-ПРАВОВИЙ ЗМІСТ ПРИЗНАЧЕННЯ ОСВІТИ 80 


\section{CONTENTS}

Kurbatova I.S.

ON ENSURING THE PROSECUTOR'S RIGHTS

OF THE PERSON DURING THE PRE-TRIAL INVESTIGATION.

Bilko O.P.

CRIMINOGENIC SITUATION IN UKRAINE AND ITS INFLUENCE

ON CREDIT-FINANCIAL ACTIVITY OF BANK INSTITUTIONS.

Viter D.V.

CERTAIN DIRECTIONS OF IMPROVING THE USE OF FORENSIC EXAMINATIONS

IN THE INVESTIGATION OF CRIMES

IN THE FIELD OF FINANCING SOCIAL TARGETS

Guivan P.D.

FEATURES OF THE SOCIAL MANIFESTATION OF TIME

IN ITS USE IN THE REGULATION OF LEGAL RELATIONS.

Derkach I.M., Diachenko S.V.

THE FORECLOSURE ON THE SUBJECT OF A MORTGAGE

Kostytskyi V.V.

SOCIOLOGICAL AND LEGAL CONDITIONALITY OF THE PLURALISM

OF MODERN LEGAL UNDERSTANDING

Larchenko M.O.

MODELING OF QUANTITATIVE CRIME INDICATORS USING CLUSTER

AND CANONICAL ANALYSIS ALGORITHMS

Melnyk Ya.Ya.

SECURITY OF THE TEXT IDEOLOGY OF SOCIAL LAW:

ANTHROPOLOGICAL-COMMUNICATIVE ASPECT.

Novytska N.B., Taraniuk T.O.

PECULIARITIES OF LEGAL REGULATION

OF INTELLECTUAL PROPERTY RIGHT TO A WORK CREATED

IN THE PROCESS OF EXECUTION OF AN EMPLOYMENT CONTRACT

Petrova I.A., Sylenok K.P., Chekin D.O.

MEDIATION AS A FORM OF USE OF SPECIAL KNOWLEDGE IN CIVIL AND ECONOMIC PROCESS

Salmanova K.V., Diachenko S.V.

THE RIGHT OF AN INDIVIDUAL TO DONATE

AS A PERSONAL NON-PROPERTY RIGHT. JUDICIAL PROTECTION

Spiesivtsev D.S.

PROTECTIVE PROPERTIES OF TECHNICAL INVENTORY

OF IMMOVABLE PROPERTY PLACED ON THE LAND PLOT

Tymoshenko M.O.

ON THE QUESTION OF THE SOCIOLOGICAL AND LEGAL CONTENT

OF THE PURPOSE OF EDUCATION. 
УДК 343.163

DOI https://doi.org/10.37687/2413-6433.2020-1.1

Курбатова I.C.,

кандидат юридичних наук, доцент кафедри кримінального права та кримінології Університету державної фіскальної служби України ORCID: 0000-0002-2677-4376

\section{ЩОДО ЗАБЕЗПЕЧЕННЯ ПРОКУРОРОМ ПРАВ ОСОБИ ПІД ЧАС ДОСУДОВОГО РОЗСЛІДУВАННЯ}

\section{ON ENSURING THE PROSECUTOR'S RIGHTS OF THE PERSON DURING THE PRE-TRIAL INVESTIGATION}

Здійснено теоретичний та нормативно-правовий аналіз діяльності прокурора щодо захисту прав та законних інтересів особи у кримінальному провадженні під час досудового розслідування. Основна мета роботи полягає в дослідженні проблемних питань, пов’язаних з участю прокурора в кримінальному процесі, формуванні та науковому обгрунтуванні висновків і пропозицій, спрямованих на вдосконалення діяльності прокурора під час досудового розслідування з метою захисту прав і свобод людини і громадянина.

Значна увага приділена аналізу нормативно-правового регулювання повідомлення особі про підозру у вчиненні кримінального правопорушення, адже саме із цього моменту настає стадія притягнення особи до кримінальної відповідальності та розпочинається строк, протягом якого повинно бути закінчено досудове розслідування.

Акцентовано увагу на недоліках у визначенні критеріїв розумних строків, що на практиці часто приводить до порушення прав та законних інтересів особи, а також запропоновано шляхи покращення взаємодії слідчого та прокурора з метою недопущення порушень строків досудового розслідування.

Встановлено, що запроваджений чинним КПК України нагляд прокурора за додержанням законів під час досудового розслідування у формі процесуального керівництва досудовим розслідуванням є основою формування управлінських відносин між прокурором як процесуальним керівником у конкретному кримінальному провадженні та слідчим, що його розслідує. Особливостями такої взаємодії є те, що вони передбачають, з одного боку, обов'язок слідчого погоджувати у прокурора клопотання про застосування заходів забезпечення кримінального провадження, повідомлення про підозру, проведення слідчих (розшукових) та негласних слідчих (розшукових) дій, подання йому на затвердження обвинувального акта, клопотання про застосування примусових заходів медичного або виховного характеру, а з іншого - залишають за слідчим право самостійно розпочинати досудове розслідування за наявності підстав, проводити слідчі (розшукові) та негласні слідчі (розшукові) дії, доручати їх проведення відповідним оперативним підрозділам, призначати перевірки і ревізії у порядку, визначеному законом, приймати процесуальні рішення, у тому числі щодо закриття кримінального провадження, здійснювати інші повноваження щодо захисту прав та законних інтересів особи, передбачені КПК України.

Констатовано, що, вирішуючи питання про встановлення строків у цьому випадку, законодавець мабуть виходив із того, що прокурор, здійснюючи процесуальне керівництво, безпосередньо несе відповідальність за своєчасність і законність прийняття органами досудового розслідування процесуальних рішень, а також проведення слідчих дій, спрямованих на встановлення та перевірку доказів у кримінальному провадженні, отримання таких доказів з підстав та у порядку, передбаченому законом, дотримання правил їх належності та допустимості. Саме відсутність встановлених строків для прокурора щодо погодження або відмови у погодженні клопотань слідчого до слідчого судді про надання дозволу на проведення слідчих (розшукових) дій, негласних слідчих (розшукових) дій, інших процесуальних дій призводить до порушення дотримання строків під час проведення досудового розслідування.

Сформульовано висновок, що мають місце проблемні питання у сфері забезпечення прав особи під час досудового розслідування, які повинні вивчатися вченими та реалізовуватися практиками, а виявлені при цьому недоліки мають усуватися під час подальшого реформування

ключові слова: прокурор, повідомлення про підозру, розумні строки, кримінальне провадження.

The theoretical and normative legal analysis of the prosecutor's activity concerning the protection of the rights and legitimate interests of the person in criminal proceedings during the pre-trial investigation has been carried out. The main purpose of the work is to investigate problematic issues related to the involvement of the prosecutor in the criminal process, to formulate and substantiate the conclusions and proposals aimed at improving the prosecutor's activity during the pre-trial investigation in order to protect the rights and freedoms of the individual and the citizen. 
Much attention is paid to the analysis of the legal regulation of the notification to a person of a suspected criminal offense, since it is from this moment that the stage of bringing a person to criminal responsibility comes and the term within which the pre-trial investigation should be completed begins.

Attention is drawn to the shortcomings in the definition of reasonable time criteria, which in practice often lead to violations of the rights and legitimate interests of the individual, as well as ways to improve the interaction between the investigator and the prosecutor in order to prevent violations of the pre-trial investigation period.

It is established that the prosecutor's supervision of observance of laws introduced by the current CPC of Ukraine during pre-trial investigation in the form of procedural guidance of pre-trial investigation is the basis for forming administrative relations between the prosecutor as procedural manager in a particular criminal proceeding and the investigator investigating it. The peculiarities of such interaction are that they provide, on the one hand, the duty of the investigator to agree with the prosecutor on the application of measures to ensure criminal proceedings, notification of suspicion, investigative (investigative) and covert investigative (investigative) actions, submission to him for approval indictment, a request for the application of coercive measures of a medical or educational nature, and on the other - leave the investigator the right to independently initiate a pre-trial investigation if there are grounds, investigative (investigative) and covert investigative (investigative) actions, instruct the relevant operational units, appoint inspections and audits in the manner prescribed by law, make procedural decisions, including the closure of criminal proceedings, exercise other powers to protect the rights and legitimate interests persons provided by the CPC of Ukraine.

It was stated that in deciding the issue of setting deadlines in this case, the legislator apparently proceeded from the fact that the prosecutor, exercising procedural guidance, is directly responsible for the timeliness and legality of pre-trial investigation decisions, as well as investigative actions to establish and verify evidence. in criminal proceedings, obtaining such evidence on the grounds and in the manner prescribed by law, compliance with the rules of their affiliation and admissibility. It is the lack of deadlines for the prosecutor to approve or refuse to approve the investigator's requests to the investigating judge for permission to conduct investigative (investigative) actions, covert investigative (investigative) actions, other procedural actions leads to violation of deadlines during the pre-trial investigation.

It concludes that there are problematic issues in the field of ensuring the rights of the individual during pretrial investigation, which should be studied by scientists and implemented by practitioners, and the shortcomings identified should be eliminated during further reform.

Key words: prosecutor, suspicion notice, reasonable time, criminal proceedings.

Актуальність теми. Посилення ролі прокурорів у діяльності сторони обвинувачення шляхом здійснення ними нагляду у формі процесуального керівництва досудовим розслідуванням відповідно до ч. 2 ст. 36 Кримінального процесуального кодексу України (далі - КПК України) [1] вимагає детального дослідження реалізації ними своїх процесуальних повноважень у ключових напрямах кримінальної процесуальної діяльності, одним із яких $є$ доказування у кримінальному провадженні та забезпечення прав і законних інтересів особи під час досудового розслідування.

Очевидно, що без встановлення з достовірністю всіх зазначених у законі обставин вчинення кримінального правопорушення, що підлягають доказуванню, неможливо правильно вирішити кримінальну справу і винести законне та обґрунтоване рішення. Провадження не може бути направлене до суду, якщо досудовим розслідуванням не з'ясовано хоча б одна з таких обставин. На нашу думку, досудове розслідування має прагнути до такої ж повноти і всебічності, як і судовий розгляд, і саме це зобов'язаний забезпечити прокурор під час досудового розслідування.

Визнаючи прокурора суб'єктом доказування, дослідники підкреслюють специфіку його участі в такій діяльності: обов'язок забезпечити всебічність, повноту та неупередженість провадження досудового слідства, що зумовлені не тільки завданням нагляду за законністю, а й процесуальним керівництвом досудовим розслідуванням. Прокурор не просто досліджує всі обставини вчинення кримінального правопорушення, його діяльність зумовлена особливою процесуальною метою - обґрунтуванням підозри (обвинувачення), яке потім він буде підтримувати перед судом. У зв'язку із цим він зобов'язаний ще в процесі розслідування вжити заходів до встановлення всіх фактів, що викривають підозрюваного, піддати їх ретельній перевірці і врахувати обставини, що вказують як на користь обвинувачення, так і на користь підозрюваного. Без цього прокурор не зможе зробити обґрунтований висновок про причетність особи до вчиненого кримінального правопорушення.

Аналіз дослідження даної проблеми. Проблемам визначення поняття, змісту та сутності діяльності прокурора у кримінальному провадженні приділяли увагу у своїх роботах І.В. Гловюк, П.М. Каркач, В.І. Малюга, О.Р. Михайленко, М.А. Погорецький, М.В. Руденко, О.Ю. Татаров, О.М. Толочко, В.Г. Уваров, М.В. Чорноусько та ін., які досліджували загальні питання правової природи прокурорського нагляду у формі процесуального керівництва досудовим розслідуванням, його співвідношення з функцією кримінального переслідування та підтримання державного обвинувачення.

Проте питання участі прокурора в доказуванні з метою захисту прав та законних інте- 
ресів особи під час досудового розслідування залишається недостатньо дослідженим, хоча воно $є$ однією з досить важливих складових частин кримінального провадження, і прокурор, як процесуальний керівник не може залишатися осторонь цього питання під час досудового розслідування.

На підтвердження цієї позиції можна навести думку М.А. Погорецького, згідно з якою результати аналізу положень норм доказового права чинного КПК України дають підстави для обґрунтованого висновку, що докази у кримінальному провадженні з'являються не лише на судових стадіях, а й на стадії досудового розслідування, оскільки саме на цій стадії слідчий, прокурор та слідчий суддя, як і суд, встановлюють наявність чи відсутність фрактів та обставин, що мають значення для кримінального провадження та підлягають доказуванню [2, с. 18].

Виклад основного матеріалу. Запроваджений чинним КПК України нагляд прокурора за додержанням законів під час досудового розслідування у формі процесуального керівництва досудовим розслідуванням $€$ основою формування управлінських відносин між прокурором як процесуальним керівником у конкретному кримінальному провадженні та слідчим, що його розслідує. Особливостями такої взаємодії $€$ те, що вони передбачають, з одного боку, обов'язок слідчого погоджувати у прокурора клопотання про застосування заходів забезпечення кримінального провадження, повідомлення про підозру, проведення слідчих (розшукових) та негласних слідчих (розшукових) дій, подання йому на затвердження обвинувального акта, клопотання про застосування примусових заходів медичного або виховного характеру, а з іншого - залишають за слідчим право самостійно розпочинати досудове розслідування за наявності підстав, проводити слідчі (розшукові) та негласні слідчі (розшукові) дії, доручати їх проведення відповідним оперативним підрозділам, призначати перевірки і ревізії у порядку, визначеному законом, приймати процесуальні рішення, у тому числі щодо закриття кримінального провадження, здійснювати інші повноваження щодо захисту прав та законних інтересів особи, передбачені КПК України. Водночас слідчий, відповідно до ч. 1 ст. 40 КПК України, має займати активну позицію у кримінальному провадженні, не чекати від прокурора, який є процесуальним керівником даного провадження, вказівок щодо подальших дій, а самостійно ініціювати їх, до чого стимулює покладена на нього відповідальність за законність та своєчасність здійснення процесуальних дій за гарантованої йому самостійності (ч. 5 ст. 40 КПК України).

Ми підтримуємо думку Л.А. Гарбовського щодо взаємодії у кримінальному провадженні, головною ціллю якої $є$ створення єдиного і закінченого циклу зкоординованих заходів щодо ціле- направленого пошуку, накопичення, обробки, аналізу, використання, об'єктивної оцінки і реалізації в установленому порядку інформації про кримінальні правопорушення, осіб, які їх вчинили, та забезпечення відшкодування завданої кримінальним правопорушенням шкоди [3, c. 188].

Найбільш активною взаємодія прокурора та слідчого розпочинається з моменту повідомлення особі про підозру у вчиненні кримінального правопорушення, саме з цього моменту настає стадія притягнення особи до кримінальної відповідальності (п. 14 ч. 1 ст. 3 КПК України) та розпочинається строк, протягом якого повинно бути закінчено досудове розслідування (ст. 219 КПК України).

У практичній діяльності процедура повідомлення особі про підозру у вчиненні кримінального правопорушення спричиняє виникнення чисельних запитань та нерідко відбувається з порушенням норм КПК України [4, с. 82].

У кримінальному провадженні сторони у більшості випадків мають протилежні інтереси. Так, сторона захисту орієнтована на збирання доказів, що виправдовують або пом'якшують вину підозрюваного, суд здійснює судовий контроль за дотриманням прав, свобод та інтересів осіб у кримінальному провадженні, а діяльність слідчого та прокурора набуває здебільшого обвинувального характеру. Не дивлячись на те, що відповідно до вимог ч. 2 ст. 9 КПК України слідчий, прокурор зобов'язані перевірити та оцінити всі докази, на які посилається підозрюваний та його захисник, проте сторона обвинувачення вже не так активно за своєю ініціативою виявляє ті обставини, що виправдовують підозрюваного.

Теоретично повідомлення про підозру особі ще не означає, що вона обов'язково буде притягнута до кримінальної відповідальності. Під час подальшого розслідування можуть бути виявлені обставини, які унеможливлять кримінальну відповідальність, а саме: встановлена невинуватість особи, якій вручено повідомлення про підозру, або з'являться інші передумови для припинення досудового розслідування, у зв'язку із чим таке кримінальне провадження повинно бути закрито з підстав, передбачених ст. 284 КПК України.

Проте на практиці слідчий, прокурор після повідомлення особі про підозру у вчиненні кримінального правопорушення опиняються у ситуації, коли відступати назад небезпечно. Це пов'язано з тим, що відповідно до п. 3 Порядку організації діяльності прокурорів і слідчих органів прокуратури у кримінальному провадженні затвердженого наказом Генерального прокурора від 28.03.2019 р. № 51 [5] прокурор зобов'язаний перевірити законність і обгрунтованість рішення про закриття кримінального провадження, у тому числі повноту проведення досудового розслідування, захист інтересів учасників кримінального 
провадження, вирішення питань про спеціальну конфіскацію, долю майна та документів, вилучених або наданих під час досудового розслідування, скасування обмежувальних заходів.

Водночас відповідно до п. 2 цього Порядку керівники прокуратур усіх рівнів зобов'язані у межах своїх повноважень скасовувати незаконні та необґрунтовані постанови слідчих і прокурорів, зокрема про закриття кримінальних проваджень, зупинення досудового розслідування, незалежно від їх оскарження учасниками кримінального провадження та вживати вичерпних заходів реагування щодо осіб, винних у порушенні вимог КПК України чи Кримінального кодексу України, наслідком якого стало незаконне притягнення громадян до кримінальної відповідальності чи порушення інтересів держави [5].

Отже, з одного боку, Порядок вимагає від прокурора перевіряти законність та обґрунтованість рішення про закриття кримінального провадження, захищати інтереси учасників кримінального провадження, а 3 іншого - закриття кримінального провадження за реабілітуючими підставами щодо підозрюваного є обов'язковим для розгляду питання про відповідальність прокурора - процесуального керівника, оскільки був факт незаконного притягнення особи до кримінальної відповідальності.

У зв'язку із цим під загрозою притягнення до відповідальності за закриття кримінальної справи, у якій особі пред'явлено обвинувачення, правоохоронці фральсифікували докази і застосовували незаконні методи розслідування, навіть катування. I все це заради того, щоб за будь-яку ціну довести обвинувачення [6, с. 98].

Такий стан оцінки діяльності правоохоронців недопустимий, необхідно змістити акцент із самого фракту притягнення особи до кримінальної відповідальності, стосовно якої на певному етапі встановлена її невинуватість, тобто висунуте обвинувачення не підтвердилося, на об'єктивну перевірку наявності на момент оголошення особі про підозру підстав та законність при цьому дій правоохоронних органів. У такому випадку прокурор, закриваючи кримінальне провадження на підставі закону, не буде відчувати на собі тягар заходів реагування керівника прокуратури.

Відповідно до вимог ст. 6 Конвенції про захист прав людини і основоположних свобод, якою гарантується право кожного на справедливий та публічний розгляд його справи впродовж розумного строку незалежним і безстороннім судом, чинний КПК України теж передбачає засаду розумності строків кримінального провадження.

Якщо термін «розумні строки» у Конвенції $€$ виправданим тому, що він не несе ніяких конкретних зобов'язань, то запровадження його у чинний КПК України ми вважаємо недореч- ним або таким, що потребує більш детального визначення. На сьогодні критерії визначення розумності строків прописані у КПК України так, що кожен може їх трактувати на свій розсуд.

Відповідно до ч. 3 ст. 28 КПК України критеріями для визначення розумності строків кримінального провадження є:

1) складність кримінального провадження, яка визначається 3 урахуванням кількості підозрюваних, обвинувачуваних та кримінальних правопорушень, щодо яких здійснюється провадження, обсягу та специфіки процесуальних дій, необхідних для здійснення досудового розслідування, тощо;

2) поведінка учасників кримінального провадження;

3) спосіб здійснення слідчим, прокурором і судом своїх повноважень.

На нашу думку, таке трактування визначення розумних строків дає можливість посадовій особі визначати розумність строків за своїм суб'єктивним переконанням, а звідси і можливі зловживання службовим становищем. Такий стан речей призвів до великої кількості звернень до Європейського суду з прав людини (ЄСПЛ), із приводу порушення права особи на розгляд iї справи судом упродовж розумного строку, в переважній більшості випадків ЄСПЛ виніс рішення на користь позивача.

Крім того, більшість звернень до ЄСПЛ, у тому числі у зв'язку з порушенням права особи на розгляд її справи судом упродовж розумного строку, збільшується. Це не тільки погіршує імідж України на міжнародному рівні, а й призводить до значних втрат Державного бюджету $[7$, с. 67].

Водночас необхідно відмітити, що результати аналізу судової практики підтверджують, що клопотання слідчого, прокурора до слідчого судді переважно розглядаються у відповідності до вимог КПК України, оскільки в законі встановлені конкретні строки. І в той же час у КПК України не передбачено чітко встановленого строку, протягом якого прокурор, здійснюючи відповідно до п. 10 ч. 2 ст. 36 КПК України нагляд за додержанням законів під час проведення досудового розслідування у формі процесуального керівництва досудовим розслідуванням, повинен погоджувати або відмовляти у погодженні клопотань слідчого до слідчого судді щодо проведення слідчих (розшукових) дій, негласних слідчих (розшукових) дій, інших процесуальних дій у випадках, передбачених КПК України. Така невизначеність призводить до необґрунтованого затягування прокурором, в окремих випадках, розгляду клопотань слідчого, а зрештою до недотримання розумних строків досудового розслідування, а звідси порушення прав і свобод учасників процесу.

Вирішуючи питання про встановлення строків у цьому випадку, законодавець, мабуть, виходив 
із того, що прокурор, здійснюючи процесуальне керівництво, безпосередньо несе відповідальність за своєчасність і законність прийняття органами досудового розслідування процесуальних рішень, а також проведення слідчих дій, спрямованих на встановлення та перевірку доказів у кримінальному провадженні, отримання таких доказів з підстав та в порядку, передбаченому законом, дотримання правил їх належності та допустимості. Саме відсутність встановлених строків для прокурора щодо погодження або відмови в погодженні клопотань слідчого до слідчого судді про надання дозволу на проведення слідчих (розшукових) дій, негласних слідчих (розшукових) дій, інших процесуальних дій призводить до порушення дотримання строків під час проведення досудового розслідування. Однак притягнути до відповідальності прокурора у такому випадку немає підстав. На думку практиків та науковців, дуже важливо чітко визначити міру відповідальності у цьому випадку.

Підставою для юридичної відповідальності прокурора - процесуального керівника має бути винесення ним незаконних і необґрунтованих процесуальних рішень, вчинення незаконних дій, конкретні прояви бездіяльності, нереагування і неналежне реагування на скарги учасників процесу, перевищення владних повноважень і потурання порушенням закону з боку осіб, на яких поширюються його процесуальні повноваження [7, с. 72].
У зв'язку з необхідністю покращення взаємодії слідчого та прокурора під час досудового розслідування вважаємо за доцільне внести зміни у п. 10 ч. 2 ст. 36 КПК України стосовно строку, протягом якого прокурор, здійснюючи нагляд за додержанням законів під час проведення досудового розслідування у формі процесуального керівництва досудовим розслідуванням, уповноважений погоджувати або відмовляти в погодженні клопотань слідчого до слідчого судді про проведення слідчих (розшукових) дій, негласних слідчих (розшукових) дій, інших процесуальних дій у випадках, передбачених КПК України, чи самостійно подавати слідчому судді такі клопотання.

На нашу думку, такий строк повинен бути визначений протягом 72 годин із часу отримання клопотання слідчого, а у випадку відмови в погодженні клопотання прокурор зобов'язаний письмово аргументувати своє рішення.

Висновки. Підсумовуючи викладене, зазначимо, що проблемних питань у сфері забезпечення прав особи під час досудового розслідування постає багато і виникає потреба найшвидшого їх вирішення. Ми розглянули лише окремі проблеми та погоджуємося з думкою, що будь-який закон має пройти свій шлях розвитку. Його положення повинні вивчатися вченими та реалізовуватися практиками, а виявлені при цьому недоліки мають усуватися під час подальшого рефрормування [8, с. 61].

\section{Список використаних джерел:}

1. Кримінальний процесуальний кодекс України: Науково-практичний коментар / О.М. Бандурка, Є.М. Блажівський, Є.П. Бурдоль та ін. ; за заг. ред. В.Я. Тація, В.П. Пшонки, А.В. Портнова. Харків : Право, 2012.768 с.

2. Погорецький М. Теорія кримінального процесуального доказування: проблемні питання. Право Украӥни. 2014. № 10. С. 12-24.

3. Гарбовський Л.А., Черняхович О.М. Взаємодія слідчого з оперативними підрозділами в забезпеченні розслідування шахрайства $з$ фінансовими ресурсами. Міжнародний юридичний вісник: актуальні проблеми сучасності (теорія та практика). 2018. № 3-4(12-13). С. 186-191.

4. Срьоменко І. Вдосконалення процедури повідомлення особі про підозру у вчиненні кримінального правопорушення. Вісник Наџіональної академії прокуратури України. 2017. № 1(47). С. 82-87.

5. Порядок організації діяльності прокурорів і слідчих органів прокуратури у кримінальному провадженні : затверджений Наказом Генерального прокурора від 28.03.2019 р. № 51 URL : (дата звернення: 04.03.2020).

6. Костенко С. Дотримання конституційних прав і свобод громадянина при повідомленні про підозру у вчиненні кримінального правопорушення. Вісник прокуратури. 2014. № 5(155). С. 95-103.

7. Вовк М. Шляхи вдосконалення дотримання розумних строків при проведенні досудового розслідування кримінальних проваджень. Вісник прокуратури. 2018. № 6. С. 67-73.

8. Воротинцев С. Удосконалення процесуального порядку повідомлення про підозру під час кримінального провадження. Вісник прокуратури. 2014. № 4(154). С. 60-65. 
УДК 343.9

DOI https://doi.org/10.37687/2413-6433.2020-1.2

Білько О.П., старший викладач кафедри теорії, історії права і держави та конституційного права Університету державної фіскальної служби України ORCID: 0000-0001-8337-7257

\title{
КРИМІНОГЕННА СИТУАЦІЯ В УКРАЇНІ ТА ІІЇ ВПЛИВ НА КРЕДИТНО-ФІНАНСОВУ ДІЯЛЬНІСТЬ БАНКІВСЬКИХ УСТАНОВ
}

\author{
CRIMINOGENIC SITUATION IN UKRAINE AND ITS INFLUENCE \\ ON CREDIT-FINANCIAL ACTIVITY OF BANK INSTITUTIONS
}

Стаття присвячена висвітленню сутності та особливості однієї із загроз безпеці діяльності банків, зокрема кримінальної ситуації, яка склалася у кредитно-фінансовій сфері. Визначено причини, способи, засоби і суб'єкти скоєння злочинів у сфері кредитної діяльності банків. Останнім часом на фінансовому ринку спостерігається зростаючий інтерес до кредитів. Ураховуючи це, банки надто ризиковано розширюють свої кредитні портфелі, охоче приваблюючи нових клієнтів, при цьому неуважно ставлячись до їх платоспроможності. Це призводить до масових зловживань та шахрайства. Проведено аналіз факторів, які сприяють підвищеній суспільній небезпеці злочинів у сфері банківського кредитування. Серед них слід відмітити: інтелектуальний характер злочинів, який виявляється насамперед у використанні злочинцями нових форм та методів; наявність стійкої тенденції до збільшення розмірів завданої шкоди; високий рівень латентності банківських злочинів; кримінальні інтереси в банківському секторі для переведення незаконно здобутих капіталів за кордон; тенденція до симбіозу корупції; низька ефективність правоохоронної системи та банківської безпеки щодо протидії злочинам. Звертається увага на найбільш розповсюджені й небезпечні прояви протиправного використання банківських послуг та технологій, до яких відносять: розрахункові, депозитні та кредитні операції. Наведені найбільш поширеніші механізми, які застосовуються злочинцями під час скоєння злочинів у кредитній діяльності банків, такі як: використання підроблених документів, обман щодо об'єктивного стану підприємств-позичальників, фальсифікація документів, неправочинне внесення в документи необ'єктивної інформації, в тому числі і щодо суми коштів, використання фіктивних підприємств, безпідставне надання кредитних коштів або списання їх із рахунків позичальників, застосування так званого фіктивного банкрутства, виведення кредитних коштів із банку шляхом фіктивного кредитування.

Ключові слова: безпека, злочин, банківська злочинність, кримінальна ситуачія, кредитна діяльність, кредитні операції, зловживання.

The article is sanctified to illumination of essence and one feature of threats to safety of activity of banks, in particular criminal situation that was folded in the field of credit-financial. Reasons are certain, methods, facilities and subjects of committing crime in the field of credit activity of banks. Lately at the financial market there is growing interest in credits. Banks too risky extend the credit brief-cases, gladly attracting new clients, here inattentively behaving to their solvency. In turn it results in mass abuses and swindle. The analysis of factors that assist an increase public danger of crimes in the field of the bank crediting is conducted. Among them it follows notices : intellectual character of crimes, that appears first of all in the use of new forms and methods criminals; a presence of proof tendency is to the jumboizing of the inflicted harm; high level of latentness of bank crimes; criminal interests in a bank sector for translation of the illegally obtained capitals abroad; a tendency is to symbiosis of corruption; subzero efficiency of the law-enforcement system and bank safety is in relation to counteraction to the crimes. Attention applies on the most widespread and dangerous displays of the illegal use of bank services and technologies to that take: to the calculation, deposit and credit operations. The most more widespread mechanisms over, that are used criminals at committing crime in credit activity of banks such as, are brought: the use of the counterfeited documents, deception in relation to the objective state of enterprises-borrowers, falsification of documents, incompetent bringing in the documents of the biased information, including in relation to the amount of moneys, use of fictitious enterprises groundless grant of credit funds or writing of them from the accounts of borrowers, application of the so-called fictitious bankruptcy, leadingout credit funds from bank by fictitious crediting.

Key words: safety, crime, bank criminality, criminal situation, credit activity, credit operations, abuses.

Постановка проблеми. Дослідження доводять, що більш ніж 75\% від усіх збитків, заподіяних економічною злочинністю, припадає на сфреру діяльності банківських установ. Вони все частіше використовується в технологіях злочинного збагачення у сфері ухилення від оподаткування, розкрадань грошових коштів клієнтів банку та легалізації доходів, отриманих незакон-

Випуск 1 (32), 2020 
ним шляхом. Кредитування є однією з розповсюджених i, одночасно, уразливих у кримінологічному відношенні банківських операцій. Останнім часом на фрінансовому ринку спостерігався зростаючий інтерес до кредитів як зі сторони підприємців, так і громадян. Банки надто ризиковано розширювали свої кредитні портфелі, охоче приваблювали нових клієнтів, при цьому неуважно ставлячись до їх платоспроможності. Це призвело до масових невиплат заборгованостей, зловживань та шахрайств у цій сорері [1].

Аналіз останніх досліджень і публікацій. Теоретичним і практичним питанням безпеки банківської діяльності та способам вчинення злочинів в ній присвячено праці багатьох вітчизняних і іноземних учених. Значний внесок у дослідження зазначених проблем зробили такі фахівці, як Г. Матусовський, А. Толстошеєва, В. Попович, О. Джужа, О. Кальман, А. Клочко, C. Чернявський та інші науковці.

Віддаючи належне доробку дослідників у даній сфері, слід зауважити, що на сьогодні у працях науковців здебільшого розглядаються загрози банківській діяльності загалом. Водночас поза їх увагою залишилися питання впливу криміногенної ситуації на кредитну діяльність банку. У зв'язку із цим значну увагу в нашій статті буде присвячено саме вказаним питанням.

Метою статті $€$ дослідження ситуації кримінального середовища навколо банківського кредитування, розгляд факторів, які визначають кримінальну ситуацію в банках, та основних способів здійснення злочинів у банках.

Виклад основного матеріалу. У сучасних умовах належна організація і функціонування банківської системи у державі $€$, насамперед, запорукою її економічного розвитку. Банківська сорера складає стратегічний сегмент ринкової економіки та грає провідну роль у забезпеченні стабільних економічних відносин. Зокрема в умовах ринкової економіки забезпечується потреба фізичних та юридичних осіб отримувати якісні банківські послуги, починаючи від належного здійснення платежів, надання кредитів, послуг в операціях із цінними паперами і закінчуючи своєчасним поверненням вкладів тощо. Рівень довіри клієнтів до конкретних банківських установ і до стану контролю за діяльністю кредитно-фінансової системи взагалі є чинником, який забезпечує ефективність економічної політики держави. Тому нагальним завданням державних органів влади в організації діяльності у банківській та кредитно-фінансовій сфрерах є забезпечення гарантій збереження та повернення вкладів фізичних та юридичних осіб, а також розвиток і стабільна діяльність банківських установ. Забезпечення таких гарантій має багато складових частин, і однією з них виступає своєчасне розкриття та розслідування злочинів, що вчинюються з використанням механізмів банківських послуг та технологій [2].
Як зазначають фахівці і показують статистичні дані, найбільша кількість злочинів скоюються в агропромисловому комплексі, на об'єктах паливно-енергетичного комплексу, у сорері приватизації, зовнішньоекономічної діяльності і у фрінансово-кредитній сфрері [3].

Особливу роль у банківській системі відіграє одна з головних функцій банку - кредитування суб'єктів господарської діяльності та громадян. Підвищена суспільна небезпека злочинів у сфері банківського кредитування визначається рядом факторів.

По-перше, злочини у сфері банківського кредитування завдають істотних збитків не лише комерційним банкам та вкладникам, а й негативно впливають на функціонування усієї економічної системи держави. У багатьох випадках одержані злочинцями кошти переводяться за межі України, де зберігаються на незаконно відкритих рахунках. Таким чином, крім прямих збитків, спричинених неповерненням до банків кредитних ресурсів, державним інтересам також завдається величезна шкода у вигляді прискорення інфляційних процесів, знецінення національної валюти, що, зрештою, може призвести до «знекровлення» кредитно-фінансової системи.

По-друге, злочинна діяльність такого спрямування характеризується різноманітністю, високоінтелектуальним характером, швидкою адаптацією злочинців до нових форм та методів підприємницької діяльності, що дозволяє зарахувати ці злочини до категорії особливої складності та вимагає від фахівців застосування додаткових знань та можливостей. Розслідування таких фактів у багатьох випадках надто ускладнюється тим, що його повноцінному проведенню одночасно протидіють як злочинці, так і недобросовісні банкіри. Перші, в більшості випадків, переховуються під «вивісками» легальних підприємницьких структур, використовують у злочинних цілях ім'я господарюючого суб'єкта - юридичної особи та різноманітні цивільно-правові відносини. Таке прикриття дозволяє легко маскувати злочин під легальну фрінансово-господарську діяльність, за якою дуже важко розпізнати злочинну комбінацію. Інші, здебільшого в особі керівництва банківських установ, насамперед посадових осіб, які за хабарі видали неповернуті кредити, усіляко «гальмують» слідство, використовуючи численні корупційні важелі та значні фрінансові можливості.

По-третє, слід звернути увагу на особливості діяльності банків, які формують передумови для скоєння злочинів у банківській діяльності, в тому числі і у сфрері банківського кредитування. Серед них: відсутність сприятливих умов для ефективної протидії злочинним зазіханням на власність та діяльність банків, недостатність або відсутність профілактичних заходів безпеки банків, які 
спрямовані на виявлення, локалізацію, запобігання правопорушенням, що скоюються працівниками банків, несправедлива оплата праці працівників банків, відсутність у банках пропаганди безпечної поведінки, відповідної ідеології, яка б формувала відповідний менталітет працівників щодо їх ставлення до власної безпеки, безпеки банку та ін. Традиційно провідне місце з точки зору заподіяної шкоди від злочинних зазіхань займає банківська сфера [4].

За розрахунками Національного банку України, відтік капіталу через банківську систему України складає близько 1,2 млрд. доларів США щороку [5]. Досліджуючи проблеми злочинності, можемо дійти висновку, що кримінальну ситуацію в банках визначають такі фактори: - інтелектуальний характер злочинів, який виявляється насамперед у використанні злочинцями нових форм та інститутів ринкової економіки; - наявність стійкої тенденції до щорічного зростання кількості злочинів та збільшення розмірів завданої шкоди; - високий рівень латентності банківських злочинів; - кримінальні інтереси в банківському секторі, які концентруються з метою використання банків для організації каналів переведення незаконно здобутих капіталів за кордон; - тенденція до симбіозу корупції, організованої злочинної діяльності із банківською злочинністю; - низька ефективність правоохоронної системи та банківської безпеки щодо протидії злочинам [6].

Вчинення конкретного злочину в кожному випадку визначається специфікою тієї чи іншої банківської операції, з використанням якої здійснюються злочинні дії. Слід звернути увагу на найбільш розповсюджені й небезпечні прояви протиправного використання банківських послуг та технологій [2].

Науковцями доведено, що злочини, скоєні у кредитній сорері, за сумою завданих збитків посідають провідне місце серед всіх злочинів у банківській діяльності. Такий висновок науковців підтверджується і кримінальною статистикою. Сума коштів по кримінальних справах у сорері кредитної діяльності складала 18221327 грн і 503960 доларів США. Кримінальні справи зачіпали 35\% банківських установ міста, в деяких банках було порушено протягом року по декілька справ [6].

Найбільш поширеними кримінальними механізмами, які застосовуються злочинцями під час скоєння злочинів у кредитній діяльності банків, науковці та спеціалісти правоохоронних органів називають: використання підроблених документів, обман щодо об'єктивного стану підприємств-позичальників, фальсифікація документів, неправочинне внесення в документи необ'єктивної інформації, у тому числі і щодо суми коштів, використання фріктивних підприємств безпідставне надання кредитних коштів або списання їх з рахунків позичальників, застосування так званого кримінального банкрутства, виведення кредитних коштів з банку шляхом фіктивного кредитування [6]. Характерним для злочинності у сорері кредитної діяльності $€$ те, що ії̈ учасниками є працівники банків, які, скоюючи злочини, як правило, діють у змові з позичальниками. У більше ніж половині випадків злочинні групи утворюють добровільні тимчасові об'єднання. Нерідко до складу таких груп входять керівники підприємств, головні бухгалтери, керівники підрозділів банків, а то й самі керівники банків.

Досліджуючи питання банківської злочинності і джерела злочинності у сорері кредитної діяльності банків, не можна не помітити не тільки їі кількісного зростання, а і збільшення збитків від такого негативного явища. Останнім часом спостерігається тенденція до погіршення ситуації з посадовими зловживаннями та недобросовісною поведінкою працівників компаній. Світові 3MІ спостерігають збільшення кількості

\begin{tabular}{|c|c|c|c|c|}
\hline $\begin{array}{l}\text { № } \\
\text { П. }\end{array}$ & $\begin{array}{c}\text { Вид } \\
\text { операції }\end{array}$ & $\begin{array}{c}\text { Основні способи } \\
\text { здійснення злочинів }\end{array}$ & $\begin{array}{c}\text { Засоби } \\
\text { здійснення 3лочинів }\end{array}$ & $\begin{array}{c}\text { Особи, } \\
\text { які здійснюють злочин }\end{array}$ \\
\hline 1 & $\begin{array}{l}\text { Розрахункові } \\
\text { операції }\end{array}$ & $\begin{array}{l}\text { підробка документів внесення } \\
\text { шахрайських змін у документи } \\
\text { розкрадання документів } \\
\text { неправочинне проникнення } \\
\text { в комп'ютерну систему банка } \\
\text { та в електронні системи } \\
\text { банківських рахунків }\end{array}$ & $\begin{array}{l}\text { розрахунково-платіжні } \\
\text { банківські документи (чеки, } \\
\text { векселі, тратти) пластикові } \\
\text { картки комп'ютерні віруси } \\
\text { помилкові комп'ютерні команди }\end{array}$ & $\begin{array}{l}\text { співробітники банку } \\
\text { особи, які не є } \\
\text { співробітниками банку }\end{array}$ \\
\hline 2 & $\begin{array}{l}\text { Депозитні } \\
\text { операції }\end{array}$ & $\begin{array}{l}\text { неправочинне проникнення } \\
\text { в комп'ютерну систему банка } \\
\text { підробка документів }\end{array}$ & $\begin{array}{l}\text { депозитні сертифрікати } \\
\text { комп'ютерні віруси помилкові } \\
\text { комп'ютерні команди }\end{array}$ & $\begin{array}{l}\text { здебільшого } \\
\text { співробітники банку }\end{array}$ \\
\hline 3 & $\begin{array}{l}\text { Кредитні } \\
\text { операції }\end{array}$ & $\begin{array}{l}\text { незаконне одержання кредиту } \\
\text { навмисне неповернення } \\
\text { кредиту невиплата відсотків } \\
\text { за кредитом }\end{array}$ & $\begin{array}{l}\text { надання позичальником } \\
\text { підроблених документів } \\
\text { про кредитоспроможність } \\
\text { або документів, що } \\
\text { містять недостовірні дані } \\
\text { фальсифікація надання } \\
\text { застави під кредит навмисне } \\
\text { банкрутство }\end{array}$ & $\begin{array}{l}\text { особи, які не } є \\
\text { співробітниками банку } \\
\text { співробітники банку у } \\
\text { змові з третіми особами }\end{array}$ \\
\hline
\end{tabular}


крадіжок, скоєних працівниками установ, організацій та господарюючих суб'єктів. Як вказують фахівці кадрової безпеки, саме сьогоднішні взаємовідносини в компаніях створили умови, за яких збігаються потреби, можливості і самовиправдання в поведінці працівників як сприятливі підстави для скоєння ними злочинів [7].

Дослідники, фахівці кадрової безпеки та психологи пояснення такій ситуації знаходять у рівні профресіоналізму працівників. Прагнучи до удосконалення професійної майстерності свого персоналу, банки таким чином фрормують не лише здатність виконувати на високому професійному рівні виробничі завдання, а і на такому ж рівні скоювати посадові злочини. 3 підвищенням рівня професіоналізму працівників підвищується і рівень загрози від них для банків. Тобто, як висновок, можемо говорити, що загрози від персоналу в кредитній діяльності банків є постійними і гострота такої проблеми має тенденцію до підвищення із зростанням рівня професійної майстерності працівників. Однак реалізація таких загроз може здійснюватись лише за умов, які сприяють злочинній поведінці працівників. Можливість скоєння злочинів за несприятливих умов падає втричі, і лише одна четверта працівників може шукати можливості для скоєння злочину за несприятливих для цього умов [8]. Високий професійний рівень працівників дає їм змогу досить ефективно використовувати наявні технологічні процедури здійснення кредитної діяльності для скоєння різноманітних злочинів. За таких умов розкриття таких справ складає всього 8-10\%, а відшкодування збитків, завданих банківськими працівниками в операціях кредитної діяльності, може складати всього 2\% [9]. Отже, банки як фінансові установи посідають провідне місце у злочинній діяльності їх посадових осіб. Таке «почесне» місце банків серед суб'єктів економічних галузей зумовлюється ще і обсягами завданої шкоди. Більше половини викритих у банках складають злочини з сумою збитків 100 000,00 гривень [10].

Висновки. Отже, характеризуючи кримінальну ситуацію у сфері кредитної діяльності, можна зробити підсумок про те, що:
- у всіх випадках на першому місці виступає загроза втрати банками своїх кредитних коштів як результат кримінальних зазіхань на їхню кредитну діяльність;

- криміналізація кредитних відносин банків із своїми кредиторами і клієнтами, крім матеріальних збитків, фрормує загрозу втрати клієнтів та іміджу банків;

- формування кредитних ресурсів за рахунок капіталу пов'язаних осіб банків зумовлює загрозу їх втрати у критичних для банку ситуаціях;

- враховуючи наявність серед суб'єктів злочинної діяльності працівників банків, останнім не слід очікувати суттєвого зниження кримінальних загроз у їх кредитній діяльності, такі загрози і надалі будуть мати стійку тенденцію до поширення;

- банківським установам не слід сподіватись на суттєве відшкодування збитків, завданих їм злочинною діяльністю їхніх працівників у процесі кредитної діяльності, як правило, такі збитки будуть складати безповоротні втрати банків [11].

Тому очевидно, що банківська система знаходиться в зоні підвищеного ризику. Це зумовлюється тим, що практично вся банківська діяльність $є$ досить ризиковою. Значна кількість як зовнішніх, так і внутрішніх загроз можуть завдати роботі банку, його співробітникам та клієнтам суттєвих втрат. Різноманітність злочинів, що вчинюються у цій сфері, а також «яскравість» таких прикладів дозволяють постійно і ретельно досліджувати зміст розділів Особливої частини КК України. За умов, що склалися, банки повинні систематично відстежувати наявність усіх видів загроз, вивчати можливості та шляхи їх попередження, вживати всіх можливих заходів щодо їх локалізації та нейтралізації шкідливих наслідків. Що стосується органів державної влади, то їхнім нагальним завданням в організації діяльності у банківській та кредитно-фінансовій сферах $€$ забезпечення гарантій збереження та повернення вкладів фрізичних та юридичних осіб. Забезпечення таких гарантій має багато складових частин, і однією з них виступає своєчасне розкриття та розслідування злочинів, що вчинюються з використанням механізмів банківських послуг та технологій.

\section{Список використаних джерел:}

1. Особливості розслідування злочинів, вчинених шляхом кредитно-фінансових операцій: Методичні рекомендації / О.В. Пчеліна, В.В. Корнієнко. Харків : Харківській нац. ун-т внутр. справ, 2011. 36 с.

2. Клочко А.М. Злочини у сфері банківської діяльності. Правовий вісник Украйнської академії банківськоі справи. 2014. № 1. С. 68-71.

3. Всесвітній огляд економічних злочинів (Україна), грудень 2019 / Price Waterhouse Coopers. URL : www.pwc. com.ua.

4. Кальман О.Г. Економічна злочинність в Україні: стан, тенденції, протидія. Вісник Луганського державного університету внутрішніх справ імені Е.О. Дідоренка. Луганськ, 2010. № 5.

5. Кириченко О.А. Управління фінансово-економічною безпекою : навч. посіб. Київ : Університет «КРОК», 2010. $480 \mathrm{c}$.

6. Чернявський С.С. Методика розслідування злочинів у сфері банківського кредитування : автореф. дис...канд. юрид. наук : 12.00.009. Київ, 2009. 22 с. 
7. Самоукина Н.В. Незаменимый сотрудник и кадровая безопасность. Москва : Вершина, 2008. 176 с.

8. Зубок М.І. Забезпечення безпеки підприємства, банку в роботі з кадрами. Частина перша. Бизнес и безопасность. Київ, 2010. № 5. С. 44-46.

9. Храните ваши деньги...(О состоянии сферы банковской безопасности в Украине). URL: http://www.bos.dn.ua/ view article.php?id article $=713$.

$1 \overline{0}$. Яременко С.М. Забезпечення економічної безпеки діяльності банків : дис... канд. економ. наук : 08.00.08. Київ, 2010. 247 с.

11. Толстошеєва А. Вплив криміногенної ситуації України на кредитну діяльність банків. Економічний аналіз : зб. наук. праць ; Тернопільський національний економічний університет / редкол. : С.І. Шкарабан (голов. ред.) та ін. Тернопіль : Видавничо-поліграфічний центр Тернопільського національного економічного університету «Економічна думка», 2013. Вип. 12. Частина 2. С. 106-111. 
Bimep Д.В., аспірант Харківського науково-дослідного інституту судових експертиз імені заслуженого професора М.С. Бокаріуса ORCID: 0000-0003-4564-0610

\title{
ОКРЕМІ НАПРЯМИ ВДОСКОНАЛЕННЯ ВИКОРИСТАННЯ СУДОВИХ ЕКСПЕРТИЗ ПІД ЧАС РОЗСЛІДУВАННЯ ЗЛОЧИНІВ У СФЕРІ ФІНАНСУВАННЯ СОЦІАЛЬНИХ ЦІЛЬОВИХ ПРОГРАМ
}

\section{CERTAIN DIRECTIONS OF IMPROVING THE USE OF FORENSIC EXAMINATIONS IN THE INVESTIGATION OF CRIMES IN THE FIELD OF FINANCING SOCIAL TARGETS}

\begin{abstract}
У статті підкреслено, що злочини в сфері фінансуванні соціальних цільових програм можуть бути різними, оскільки відрізняються способами вчинення, предметом злочинного посягання тощо, однак ці злочини об'єднані тим, що мають корисливу мотивацію дій злочинця. Зауважено, що напрями використання судових експертиз та їх конкретні різновиди під час розслідування злочинів у сфері фінансування соціальних цільових програм залежать, насамперед, від способу вчинення конкретного злочину. Це зумовлює важливість вдосконалення та підвищення ефективності розслідування шляхом розробки окремих методик розслідування злочинів такого типу та експертних методик, що дозволяють якісно провести призначені експертизи. Розроблення таких методик дозволить більш чітко розуміти, які саме судові експертизи та в якій послідовності необхідно провести для з'ясування обставин розглядуваних злочинів. Вказано, що підвищення ефективності використання судових експертиз під час розслідування злочинів у сфері фінансуванні соціальних цільових програм має відбуватись у різних площинах, а найбільш актуальними сьогодні є сфери нормативно-правового та науково-технічного забезпечення, що передбачають врахування та широке використання в експертних дослідженнях наукових досягнень. Доведено, що науково-технічне забезпечення проведення експертиз включає запровадження досягнень науки й техніки в практику, оснащення сучасними науковими здобутками, зокрема й технічно-технологічне, а також методично-методологічне забезпечення проведення таких експертиз. Констатовано, що нормативно-правове забезпечення проведення судових експертиз можна умовно поділити на декілька рівнів із виділенням нормативно-правових актів: загального характеру; процесуального або галузевого характеру; відомчого характеру; присвячених проведенню різних (спеціальних) видів судових експертиз, а вдосконалення проведення судових експертиз під час розслідування злочинів у сфері фінансування соціальних цільових програм має відбуватися із застосуванням нормативно-правових актів всіх окреслених вище рівнів. Зокрема, це стосується правової регламентації діяльності експерта, його правового статусу та повноважень.
\end{abstract}

Ключові слова: судові експертизи, злочини, науково-технічне забезпечення, нормативно-правові акти, окремі методики.

The article emphasizes that crimes in the field of financing socially targeted programs may be different because they differ in the ways they are committed, the subject of criminal encroachment, etc., however, these crimes are united by the fact that they have a selfish motivation for the criminal. It is noted that the directions of use of forensic examinations and their specific varieties in the investigation of crimes in the field of financing social target programs depend, first of all, on the method of committing a specific crime. This determines the importance of improving and enhancing the effectiveness of the investigation by developing separate methods of investigating crimes of this type and expert methods that allow for quality examinations. The development of such methods will allow a clearer understanding of which forensic examinations and in what sequence should be conducted to clarify the circumstances of the crimes in question. It is indicated that improving the efficiency of forensic science in the investigation of crimes in the field of financing social target programs should take place in different areas, and the most relevant today are the areas of legal and scientific-technical support. It is proved that scientific and technical support of examinations includes the introduction of scientific and technical achievements in practice, equipping with modern scientific achievements, in particular, technical and technological, as well as methodological and methodological support of such examinations. It is stated that the legal support of forensic examinations can be divided into several levels with the allocation of regulations: general; procedural or sectoral nature; departmental nature; devoted to various (special) types of forensic examinations, and the improvement of forensic examinations in the investigation of crimes in the field of financing social target programs should take place with the application of regulations of all levels outlined above. In particular, this applies to the legal regulation of the expert, his legal status and powers.

Key words: forensic examinations, crimes, scientific and technical support, normative legal acts, separate methods. 
Раніше нами зазначалося, що фрінансування соціальних цільових програм може різнитися за джерелами, способами, напрямами та метою відповідного фінансування, а також було виділено два основні різновиди таких програм: соціальна цільова програма у пріоритетних сфрерах людської діяльності та соціальна цільова програма підтримки розвитку регіону, однак на сьогодні відсутня чітка законодавча регламентація понять [1, с. 11]. Отже, злочини у сфері фрінансуванні соціальних цільових програм також можуть бути різними, оскільки відрізняються способами вчинення, предметом злочинного посягання тощо, однак ці злочини об'єднані тим, що мають корисливу мотивацію дій злочинця. Науковцями підкреслювалось, що способи вчинення злочинів у сорері фрінансування соціальних цільових програм можуть бути пов'язаними 3 незаконним: отриманням коштів, зокрема й бюджетних; витрачанням коштів, виділених на фінансування цільових програм; відшкодуванням отриманих коштів (наприклад, використання фріктивних документів, що містять завідомо неправдиві дані про балансову вартість придбаної першої сільськогосподарської техніки 3 метою отримання фрінансової підтримки) [2, с. 324].

Зауважимо, що напрями використання судових експертиз та їх конкретні різновиди під час розслідування злочинів у сфері фінансування соціальних цільових програм залежать, насамперед, від способу вчинення конкретного злочину. Це зумовлює важливість вдосконалення та підвищення ефрективності розслідування шляхом розробки окремих методик розслідування злочинів такого типу та експертних методик, що дозволяють якісно провести призначені експертизи.

Криміналістичні методики, як наголошують науковці, $є$ засобом практичної реалізації положень (рекомендацій) криміналістичної техніки та криміналістичної тактики, бо поза реальними умовами розслідування конкретних злочинів неможливе їх застосування й використання [3, с. 235]. У своїх наукових працях Р.Л. Степанюк виділяе головні принципи побудови будьякої окремої методики розслідування: правова, наукова та інфооммаційно-практична основи. Він акцентує увагу на тому, що до джерел формування криміналістичних методик розслідування злочинів, учинених у бюджетній сфері, належать правові та наукові джерела, практика відповідної злочинної та правоохоронної діяльності щодо протидії зазначеним злочинам [4, с. 145].

Розроблення методик розслідування злочинів у сорері фрінансування соціальних цільових програм ускладнена тим, що такі злочини різняться залежно від конкретного виду соціальної цільової програми. Разом із тим необхідно розробити методики розслідування типових злочинів у цій сфері з урахуванням відповідних експертиз та експертних методик, наприклад методики роз- слідування злочинів у сфері фрінансуванні освітніх, медичних, житлових, сільськогосподарських та інших соціальних цільових програм. Саме тому важливим $€$ розроблення методик розслідування корисливих злочинів, наприклад, у системі охорони здоров'я; злочинів, які пов'язані з виділенням бюджетних коштів на молодіжні соціальні цільові програми й програми розвитку регіонів, а також визначення тих видів експертиз, що доцільно призначати під час їх розслідування. Вбачається також доцільним включати до методик розслідування ті види експертиз, які дозволять швидко розслідувати найпоширеніші способи вчинення злочинів, що пов'язані з нецільовим використанням бюджетних коштів і незаконним отриманням кредиту, а саме державного цільового, а також ті злочини, що здійснюються під час державних закупівель - у процесі реалізації соціальних цільових програм. Розроблення таких методик дозволить більш чітко розуміти, які саме судові експертизи та в якій послідовності необхідно провести для з'ясування обставин розглядуваних злочинів.

Під час розслідування злочинів у сорері фінансування соціальних цільових програм необхідно брати до уваги й те, на що свого часу вказував Р.Л. Степанюк, - на необхідність розробки окремих методик розслідування злочинів у сфрері державних закупівель, а саме: шахрайства, вчиненого в сфері державних закупівель; привласнення, розтрати майна або заволодіння ним шляхом зловживання службовим становищем під час здійснення державних закупівель; методику розслідування одержання неправомірної вигоди у сфрері державних закупівель; зловживання службовим становищем під час здійснення державних закупівель; халатність, вчинена під час здійснення державних закупівель; службове підроблення під час здійснення державних закупівель [5, с. 115].

Підвищення ефективності використання судових експертиз під час розслідування злочинів у сорері фрінансуванні соціальних цільових програм має відбуватись у різних площинах, зокрема, найбільш актуальними сьогодні представляються сорери нормативно-правового та науково-технічного забезпечення. Закон України «Про судову експертизу» визначає в якості мети судової експертизи забезпечення правосуддя України незалежною, кваліфікованою та об'єктивною експертизою, орієнтованою на максимальне використання досягнень науки і техніки [6]. Отже, одним із шляхів вдосконалення використання судових експертиз під час розслідування злочинів у ссрері фрінансуванні соціальних цільових програм має бути визнано його наукове забезпечення.

Слід погодитись із П.Т. Скорченко, який пропонує до наукового забезпечення відносити: наукове тлумачення законодавчих актів із техніко-криміналістичного забезпечення розслі- 
дування та розробку пропозицій з їх удосконалення; наукову розробку проектів підзаконних актів, пов'язаних із техніко-криміналістичним забезпеченням розслідування; наукове узагальнення практики використання техніко-криміналістичних засобів і розробку пропозицій з її удосконалення; розробку з урахуванням потреб практики нових техніко-криміналістичних засобів і методів; наукову апробацію приладів і матеріалів, що виготовляються підприємствами різних відомств, для визначення можливості їх використання із криміналістичною метою; наукову розробку прийомів, методів і методик виявлення, фіксації, вилучення й дослідження речових доказів; розробку навчальних програм та методичної літератури 3 техніко-криміналістичної підготовки кадрів та проведення практичних занять із слідчими, експертами-криміналістами тощо з вивчення нових криміналістичних методів і засобів; вивчення й поширення зарубіжного досвіду з використання в розслідуванні злочинів техніко-криміналістичних засобів [7, с. 35-37].

На переконання одних вчених, наукове забезпечення здійснюється у двох формах: науково-технічне (пошук, вибір, пристосування та використання досягнень науково-технічного прогресу в навчальному процесі); науково-методичне забезпечення (розроблення рекомендацій і створення необхідних умов для сприйняття цих рекомендацій) та інформаційне [8, с. 76]. У свою чергу, інші науковці пропонують розуміти науково-методичне забезпечення розслідування злочинів як створення умов для запровадження досягнень науки й техніки у практику, що охоплює апробацію, уточнення умов і порядку застосування, розроблення методичних рекомендацій чи інструкцій, підготовку користувачів тощо [9, с. 84].

Підсумовуючи викладене, слід зазначити, що наукове забезпечення судових експертиз під час розслідування злочинів у сфері фінансуванні соціальних цільових програм передбачає врахування та широке використання в експертних дослідженнях наукових досягнень. Крім того, слід погодитись із думкою К.В. Калюги про те, що практична реалізація завдань щодо поліпшення й оптимізації роботи експертів, їхніх завдань та функцій у сучасних умовах убачається в оснащені сучасними науковими здобутками, новітньою технікою та технологіями, розвитком перспективних напрямів тощо. Він підкреслює, що ефективність застосування криміналістичних засобів у протидії злочинності пов'язується з використанням нетрадиційних вчень (методів) чи нетрадиційного застосування фізіогноміки та фрренології, дактилоскопії та хіромантії (хірогномії, хірології), габітології, локомоції, одорології, скриберології (почеркознавства), авторознавства та графології, фоноскопії тощо [10, с. 123].

Як окремий напрям вдосконалення використання судових експертиз під час розсліду- вання злочинів у сорері фінансування соціальних цільових програм слід виділити розвиток їх нормативно-правового забезпечення. Так, B.M. Гаращук нормативно-правове забезпечення проведення судових експертиз умовно поділяє на декілька рівнів виділяючи нормативно-правові акти: загального характеру (присвячені питанням визначення правового статусу судового експерта та судової експертизи в Україні, що поширюються на всі види судових експертиз); процесуального (або галузевого) характеру (регламентують процесуальні та процедурні питання призначення та проведення судових експертиз у тих чи інших галузях судочинства); відомчого характеру (визначають правовий статус судових експертів та особливості їх діяльності в державних експертних установах різної відомчої приналежності); присвячені проведенню різних (спеціальних) видів судових експертиз [11, с. 41]. Таку позицію необхідно підтримати та підкреслити, що вдосконалення проведення судових експертиз під час розслідування злочинів у сфері фінансування соціальних цільових програм має відбуватися із застосуванням нормативно-правових актів всіх окреслених вище рівнів. Зокрема, це стосується правової регламентації діяльності експерта, його правового статусу та повноважень. У зв'язку з обранням Україною Європейського шляху розвитку, що включає в себе серед іншого і роздержавлення (демонополізацію) судової експертизи, що полягає у розвитку інституту приватних судових експертів, представляється необхідним законодавче визначення поняття «судовий експерт». При цьому судовим експертом, на нашу думку, має бути визнано особу, що має відповідну вищу освіту, освітньо-кваліфікаційний рівень не нижче спеціаліста, пройшла відповідну підготовку в державних спеціалізованих установах Міністерства юстиції України, атестована, отримала кваліфікацію судового експерта з певної спеціальності та склала присягу судового експерта.

Не претендуючи на всеохоплюючий аналіз чинного законодавства у розглядуваній сфрері, слід звернути увагу на певні моменти. Слід погодитися з раціональністю позиції Т.О. Крівцової відносно пропозиції про необхідність закріплення на законодавчому рівні чітко визначених функцій судового експерта-економіста стосовно дозволу надання рекомендацій щодо усунення як вже наявних порушень, так і з профілактики появи нових. Це пов'язано з тим, що під час судово-економічної експертизи судовий експерт-економіст досліджує та аналізує ряд специфічних характеристик та ознак економічного злочину, визначаючи детермінуючі фактори його виявлення. На жаль, результатами проведеного дослідження не цікавляться органи досудового слідства, прокуратури та інші правоохоронні органи, для них головним $є$ факт підтвердження чи спростування існування злочину, а також 
підтвердження цього речовими доказами. До таких функцій науковець пропонує віднести: право брати участь у розробці алгоритму дій із розкриття економічного злочину; право на надання розгорнутих профрілактичних заходів щодо уникнення економічного злочину; право на безпосереднє дослідження об'єкта експертизи [12, с. 51].

Згідно зі статтею 101 КПК «висновок експерта це докладний опис проведених експертом досліджень та зроблені за їх результатами висновки, обґрунтовані відповіді на питання, поставлені особою, яка залучила експерта, або слідчим суддею чи судом, що доручив проведення експертизи», а стаття 102 КПК містить вимоги щодо змісту висновку експерта [13]. Підкреслимо, що в наукових працях небезпідставно вказується на те, що експертиза призначається в тих випадках, коли потрібно застосування спеціальних знань, якими суд не володіє, а якщо суд не володіє спеціальними знаннями з тієї галузі знань, з питань якої проводиться експертиза, то, відповідно, він не зможе об'єктивно оцінити ефективність обраної методики та якість проведеного дослідження (навіть якщо інформація про останнє буде викладена в простій доступній формі) [14, с. 115].

Із цього приводу слушними є думки тих науковців, які вказують на необхідність оптимізації змістовного наповнення дослідницької частини висновку експерта, обмеження його обсягу певними розумними рамками за рахунок скорочення надмірно деталізованих описань, наукових і технічних викладок тощо [15, с. 127]. Реалізація запропонованого, вочевидь, не лише не призведе до зниження якості проведення експертизи, але й позитивно позначиться на строках її проведення, скоротить надмірне навантаження на експертів щодо складання описової частини.

Як висновок, слід зазначити, що злочини у сорері фрінансування соціальних цільових програм можуть бути різними, спрямованими проти власності, господарські, посадові, проти авторитету органів державної влади й органів державного самоврядування, але всі вони об'єднані тим, що мають корисливий характер. Предмет злочинного посягання має безпосередній вплив на процес доказування під час розслідування подібних злочинів. Процес розслідування таких злочинів вимагає використання різноманітних спеціальних знань. Вибір способу застосування спеціальних знань, а також вибір конкретного виду судової експертизи зумовлюється низкою факторів, серед яких: вид злочину у сфері фінансування соціальних цільових програм (з урахуванням і специфіки відповідної соціальної цільової програми, джерела її фінансування та інших обставин); способи вчинення такого злочину; матеріали, що перебувають у розпорядженні органів досудового розслідування. Також важливим напрямом удосконалення використання судових експертиз під час розслідування злочинів у сфері фінансування соціальних цільових програм $\epsilon$ наукове забезпечення проведення експертиз, яке включає, зокрема, й технічно-технологічне, що передбачає врахування та застосування досягнень науково-технічного прогресу, а також методично-методологічне забезпечення проведення таких експертиз.

Удосконалення (оптимізація) використання судових експертиз під час розслідування злочинів у сфері фрінансуванні соціальних цільових має відбуватися, у тому числі, й на основі вдосконалення на всіх рівнях нормативно-правової бази використання судових експертиз. Окремим напрямом вдосконалення використання судових експертиз під час розслідування злочинів у сорері фінансуванні соціальних цільових програм має стати розроблення окремих методик розслідування злочинів у сфері фінансування пріоритетних напрямків людської діяльності та у сфрері фінансування соціальних цільових програм підтримки розвитку регіону з урахуванням специфіки кожної окремої групи злочинів. Розроблення таких методик дозволить більш чітко розуміти, які саме судові експертизи та в якій послідовності необхідно провести для з'ясування обставин розглядуваних злочинів.

\section{Список використаних джерел:}

1. Вітер В.Д. До питання класифікації типових способів учинення злочинів у сфері фінансування соціальних цільових програм. Науковий вісник Дніпропетровського державного університету внутрішніх справ. 2019. № 1. C. 10-15.

2. Кікінчук В.В. Способи вчинення злочинів, пов'язаних з використанням бюджетних коштів в агропромисловому комплексі. Науковий вісник Львівського державного університету внутрішніх справ. № 3. 2013. С. 317-326.

3. Бахін В.П., Гора І.В., Цимбал П.В. Криміналістика: курс лекцій (ч. 1). Ірпінь : Акад. ДПС України, 2002. $356 \mathrm{c}$.

4. Степанюк Р.Л. Джерела та принципи формування окремих методик розслідування злочинів, учинених у бюджетній сфері України. Вісник АМСУ. Серія «Право». № 1(12). 2014. С. 138-145.

5. Степанюк Р.Л. Ситуаційний підхід у формуванні методик розслідування злочинів, вчинених у бюджетній сфері України. Право і Безпека. 2013. № 3. С. 110-115.

6. Про судову експертизу : Закон України від 25.02.1994 р. № 4038-XII. (зі змінами та доповненнями). Відомості Верховної Ради України (ВВР). 1994. № 28. Ст. 232.

7. Скорченко П.Т. Проблемы технико-криминалистического обеспечения досудебного уголовного процесса : дис. ... докт. юрид. наук. Москва, 2000. 269 с. 
8. Іщенко А.В., Ієрусалімов І.О., Удовенко Ж.В. Теорія і практика криміналістичного забезпечення процесу доказування в розслідуванні злочинів: навч. посібник. Київ : Центр учбової літератури, 2007. 160 с.

9. Бахин В.П., Лисиченко В.В. Научно-методическое обеспечение практики расследования преступлений. Актуальные проблемы судебной экспертизы и криминалистики. Киев. 1993. С. 84-87.

10. Калюга К.В. Деякі питання удосконалення експертної діяльності в України. Теорія $і$ практика судової експертизи і криміналістики: матер. всеукр. наук.-практ. конф. $з$ нагоди 85-річчя д-ра юрид. наук, проф. Ніни Іванівни Клименко (м. Київ, 27 лютого 2018 року). Київ-Маріуполь, 2018. С. 123-125.

11. Гаращук В.М. Проблеми законодавчого забезпечення судово-експертної діяльності в Україні. Актуальні питання судової експертизи і криміналістики: збірник матеріалів міжнарод. наук.-практ. конф., присвяченої 150-річчю $з$ дня народження Засл. проф. М.С. Бокаріуса (м. Харків, 18-19 квіт. 2019 р.). Харків : ХНДІСЕ, 2019. C. $40-43$.

12. Крівцова Т. О. Удосконалення правового забезпечення судово-економічної експертизи як форми економічного контролю. Бізнес-Інформ № 2. 2015. C. 48-53. URL : https://www.business-inform.net/export pdf/businessinform-2015-2_0-pages-48_53.pdf (дата звернення: 25.03.2020).

13. Кримінальний процесуальний кодекс України : Закон України від 13.04.2012 p. № 4651-VI. (зі змінами та доповненнями). Відомості Верховної Ради України (ВВР). 2013. № 9-10. № 11-12. № 13. Ст. 88.

14. Васильєва Ж.В. Зміст та структура висновку експерта в цивільному процесі. Університетські наукові записки. 2005. № 3(15). С. 111-116.

15. Каркоцький І.В. Актуальні напрямки оптимізації структури і змісту висновку експерта Теорія $і$ практика судової експертизи і криміналістики: матер. всеукр. наук.-практ. конф. 3 нагоди 85-річчя д-ра юрид. наук, проф. Ніни Іванівни Клименко (м. Київ, 27 лютого 2018 року). Київ-Маріуполь, 2018. С. 126-128. 
УДК 347.4

DOI https://doi.org/10.37687/2413-6433.2020-1.4

Гуйван П.д.,

кандидат юридичних наук, заслужений юрист України, професор Полтавського інституту бізнесу ORCID: 0000-0003-3058-4767

\title{
ОСОБЛИВОСТІ СОЦІАЛЬНОГО ПРОЯВУ ЧАСУ ПІД ЧАС ЙОГО ВИКОРИСТАННЯ В РЕГУЛЮВАННІ ПРАВОВІДНОСИН
}

\section{FEATURES OF THE SOCIAL MANIFESTATION OF TIME IN ITS USE IN THE REGULATION OF LEGAL RELATIONS}

\begin{abstract}
У даній науковій праці автор досліджує актуальну проблем розвитку соціології права, в тому числі i в рамках такого важливого напряму, як соціальні особливості сприйняття часу та його матеріальних проявів під час темпорального регулювання правовідносин. Підкреслюється, що будь-які суспільні відносини, в тому числі і врегульовані правом, зазнають часового впливу. Вони мають певну тривалість, послідовність та темпоральний взаємозв'язок. Час характеризує не лише зовнішні стосовно спостерігача явища, він також притаманний внутрішній природі людини. Відтак у соціологічному аспекті час розглядається як одне з явищ, що характеризує перебіг процесів, відносин і взаємозалежностей у соціальній сфері, ієрархічно пов' язаних між собою. Здатність людини впливати на загалом об'єктивний перебіг часу $€$ очевидною. Такий вплив виступає у формі регулювання суспільного буття. Це, звісно, не означає, що сплив часу залежать від волі і свідомості людини. Просторово-часові зв'язки складаються об'єктивно, але на базі тієї діяльності, що здійснюється людьми. Відтак усвідомлення змісту суспільного буття - людської діяльності, призводить до усвідомлення форм цього буття - соціального простору і часу. Соціальним часом вимірюється тривалість суспільних процесів та динамізм їх зміни. У першу чергу, цей вплив проявляється через можливість встановлення часових меж існування тих чи інших суб' єктивних прав та правил щодо коригування перебігу певних строків. Людині притаманне свідоме відношення до часу, вона здатна узгоджувати свою діяльність у певні періоди, планувати майбуття, усвідомлювати своє минуле. Звідси випливає детермінованість людського життя, згідно з якою не тільки попередні події обумовлюють наступні (детермінація минулим), але й наступні цілі та бажані результати визначають попередні вчинки (детермінація майбутнім). Зрештою, визначення людиною механізму обчислення строків, у тому числі під час їх використання для правового опосередкування процесів, у порядку суб'єктивного усвідомлення їх тривалості, $є$ теж істотним фактором, що підтверджує даний вплив. Встановлення часових меж здійснення цивільних прав і обов'язків забезпечує можливість вчинення відповідних дій учасниками правовідносин, спрямованих на досягнення соціально бажаних цілей.
\end{abstract}

Ключові слова: сочіальний час, перебіг строку, тривалість суспільних процесів.

In this scientific work, the author explores the current problems of sociology of law, including in such an important area as the social characteristics of the perception of time and its material manifestations in the temporal regulation of legal relations. It is emphasized that any social relations, including those regulated by law, are subject to temporary influence. They have a certain duration, sequence and temporal relationship. Time characterizes not only external to the observer phenomena, it is also inherent in the internal nature of man. Thus, in the sociological aspect, time is considered as one of the phenomena that characterizes the course of processes, relations and interdependencies in the social sphere, hierarchically interconnected. The ability of man to influence the objective course of time in general is obvious. Such influence takes the form of regulation of social life. This, of course, does not mean that the passage of time depends on the will and consciousness of man. Spatial-temporal connections are made objectively, but on the basis of human activities. Thus, awareness of the content of social existence - human activity, leads to awareness of the forms of this existence - social space and time. Social time measures the duration of social processes and the dynamism of their change. First of all, this influence is manifested through the possibility of setting time limits for the existence of certain subjective rights and rules to adjust the course of certain terms. Man has a conscious attitude to time, he is able to coordinate their activities in certain periods, plan for the future, be aware of their past. Hence the determinism of human life, according to which not only previous events determine the next (determination of the past), but also the following goals and desired results determine previous actions (determination of the future). Finally, the determination of a person's mechanism for calculating time limits, including their use for the legal mediation of processes, in the order of subjective awareness of their duration, is also an important factor that confirms this effect. Establishing time limits for the exercise of civil rights and obligations provides an opportunity for appropriate actions by the parties to legal relations aimed at achieving socially desirable goals.

Key words: social time, term, duration of social processes. 
Суспільні процеси та явища, людська діяльність, державна політика, правотворення та правозастосування відбуваються у часі. Інакше кажучи, будь-які суспільні відносини, в тому числі і врегульовані правом, зазнають часового впливу. Вони мають певну тривалість, послідовність та темпоральний взаємозв'язок. Час характеризує не лише зовнішні стосовно спостерігача явища - він також притаманний внутрішній природі людини. Відтак у сучасній науці прийнято наголошувати не тільки на реальності суто фрізичних проявів буття, а й на соціально-історичних його аспектах. Насправді, надаючи часові тільки фрізичного тлумачення як тривалості, терміну чи періоду, не можна охопити всі багатогранні його прояви. Як би об'єктивно не здійснювався перебіг часу, його сприйняття, визначення впливу на стан матерії, зрештою, дослідження темпоральних проявів можливе лише в разі відображення цього явища у свідомості людини. Адже наявний порядок процесів охоплює поступ суспільства, громади, зрештою, саме життя фрізичних осіб.

У науковій літературі останніх десятиліть часто можна зустріти посилання на «правовий», «культурний», «педагогічний» і інший простір, що свідчить про спроби встановити якісь фундаментальні і, разом з тим, елементарні онтологічні структури для здійснення конкретних видів людської діяльності. У плані фрілософссько-методологічного аналізу ці характеристики виступають не окремим простором і часом, а гранями і сторонами комплексу соціального хронотопу, що забезпечує відтворюваність і внутрішню зв'язність суспільства. Тому логічно розглядати і в соціологічному ракурсі простір і час як одне з явищ, що характеризує перебіг процесів, відносин і взаємозалежностей в соціальній сфрері, ієрархічно пов'язаних між собою [1, с. 54]. Час збігає незалежно від будь-яких зовнішніх обставин. Здатність людини впливати на загалом об'єктивний перебіг часу є очевидною. У науковій літературі було запроваджено поняття «соціального часу». Власне, це є таке розуміння даної фрілософрської категорії, яке пов'язане із впливом людини на об'єктивний перебіг часу [2, с. 615]. Соціальний час та простір виступають формами усвідомлюваного суспільного буття. Це, звісно, не означає, що вони залежать від волі і свідомості людини. Просторово-часові зв'язки складаються об'єктивно, але на базі тієї діяльності, що здійснюється людьми. Відтак усвідомлення змісту суспільного буття - людської діяльності, призводить до усвідомлення форм цього буття соціального простору і часу [3, с. 13]. Тож і час, що вивчається усіма суспільними дисциплінами, в тому числі правознавством, прийнято називати соціальним часом. Соціальним часом вимірюється тривалість суспільних процесів та динамізм їх зміни. У першу чергу, цей вплив проявляється через можливість встановлення часових меж існування тих чи інших суб'єктивних прав та правил щодо коригування перебігу певних строків. Зрештою, визначення людиною механізму обчислення строків, тобто порядку суб'єктивного усвідомлення їх тривалості, $€$ теж істотним фрактором, що підтверджує даний вплив. Відтак вивчення особливостей перцепції часу з урахуванням різноманітних суб'єктивних чинників має велике значення. Людині притаманне свідоме відношення до часу, вона здатна узгоджувати свою діяльність у певні періоди, планувати майбуття, усвідомлювати своє минуле. В онтологічному значенні соціальний час являє собою необхідну форму суспільного буття, що характеризує реальні процеси життєдіяльності людей, фріксуючи та регламентуючи їхню діяльність. У межах наукового аналізу соціального часу досліджується особистісно-часова проблематика, яка стосується темпоральної організації дорослою особою своєї свідомості, поведінки під час здійснення нею індивідуальної та групової життєдіяльності та спілкування, що визначає таку категорію, як спосіб життя $[4$, с. 6]. При цьому кожна наука вивчає ці питання під своїм кутом зору.

Як вказує В.В. Луць, специфріка соціального часу як форми руху суспільної матерії полягає в тому, що на нього накладає відбиток існуючий лише у суспільстві діалектичний зв'язок об'єктивного і суб'єктивного, необхідності і свободи. Суспільні зв'язки і відносини, становлячи зміст соціального часу, виникають на базі тієї діяльності, яка здійснюється людьми. I хоча просторово-часові фрорми, що їх опосередковують, виникають об'єктивно, усвідомлення останніх людьми в умовах суспільства стає одним із важливих чинників у науковому управління соціальними процесами [5, с. 8]. Із точки зору дослідників питання, соціальний час - це, в першу чергу, суспільний інститут, спосіб виміру та організації реального буття, його розвитку, зміни. Як слушно відмічав П.О.Сорокін, соціальний час може (і повинен) визначатися у власній системі координат, як зміна чи рух соціальних френоменів крізь інші френомени, взяті за точку відліку [2, с. 58].

Якщо розглядати зазначені питання з точки зору причинної наукової моделі, то побачимо, що саме в результаті особистісного переживання визначальних взаємозв'язків між основними подіями життя формується психологічний час як елемент соціального часу. Звідси випливає детермінованість людського життя, згідно з якою не тільки попередні події зумовлюють наступні (детермінація минулим), але й наступні цілі та бажані результати визначають попередні вчинки (детермінація майбутнім). Тож взаємодія психологічних категорій минулого, нинішнього та майбутнього уявляється як співвідношення реалізованих зв'язків між подіями хронологічного минулого, актуальних зв'язків між подіями минулого і майбутнього, що зараз тривають, 
та потенційних зв'язків між наступними хронологічними подіями [6, с. 215]. Будучи в подальшому оформленими як відносини правові (правовідносини), нові взаємозв'язки переходять до сорери регулювання відповідними юридичними механізмами. Ф. К. Савиньї свого часу зазначав, що в кожному правовідношенні можна виділити дві частини: по-перше, матерію, тобто відношення саме по собі, а, по-друге, юридичне визначення цієї матерії. Першу частину можемо називати матеріальним елементом правовідношення, або чистими фрактом у ньому, другу формальним елементом, тобто тим, що піднімає фактичне відношення до юридичної форми [7, с. 458]. До форм руху матерії, які надають визначеності правовідношенню, в першу чергу, відносяться темпоральні чинники, що забезпечують дієвість права. Під час конструювання конкретних матеріальних взаємин сторони правочинів, визначаючи їхній зміст, враховують темпоральні критерії відповідних суб'єктивних прав та обов'язків, найбільш адекватних власним приватним чи суспільним (у разі встановлення строків законодавцем) потребам. А ці потреби якраз і можуть визначатися з урахуванням чинника соціального часу [8, с. 47]. Як учасники різних відносин у соціумі та між собою, люди не тільки пізнають, а й користуються часом неоднаково. Таким чином, можемо дійти висновку про важливість впливу людини на процес пізнання природи через свій з нею зв'язок.

Усі соціальні та юридичні процеси та відносини протікають лише в одному напрямі - від минулого до майбутнього, проходячи «транзитом» через теперішнє. Така спрямованість матеріальних явищ має суб'єктивний характер та не залежить від свідомості людей, які сприймають ці процеси. Зростання впливу часу на розвиток суспільних відносин, в тому числі і тих, що мають характер правових, призводить до необхідності більш широкого наукового аналізу існуючих темпоральних категорій, надання їм більшої дієвості та адекватності. Право, процес нормотворчості та врегульовані ними суспільні взаємини також існують у часі. Вони виникають, змінюються та припиняються упродовж періодів, що мають встановлені людиною конкретні темпоральні координати. Правові норми, у свою чергу, визначають часові параметри тих чи інших матеріальних відносин. Закон досить часто в диспозицію норми включає такі темпоральні чинники, як «своєчасно», «достроково», «у строк», «негайно», «давність» тощо. У межах існування конкретних правовідносин обмеженими в часі $€$ також і складові частини їх змісту: суб'єктивні права та юридичні обов'язки учасників. Це забезпечує правовий вплив на належність поведінки суб'єктів суспільних взаємодій.

У праві часовою категорією $є$ строк, тобто відрізок в об'єктивному перебігові часу, обраний у результаті вольового вчинку людей заради встановлення меж правомірної та бажаної поведінки учасників правовідношення. Встановлення часових меж здійснення цивільних прав і обов'язків забезпечує можливість вчиненні відповідних дій учасниками правовідносин, спрямованих на досягнення соціально бажаних цілей. Тому темпоральне регулювання суб'єктивних прав та обов'язків $€$ важливим засобом юридичного впливу на поведінку учасників суспільних відносин. Соціально-правова природа та юридичне значення строків визначають правила їх установлення та визначення, які, у свою чергу, впливають на порядок застосування положень закону про строки та створюють умови для наповнення механізму впливу на суспільні взаємини конкретним змістом [9, с. 11]. Норми приватного права покликані регулювати відносини, які виникають із метою задоволення приватного інтересу, оскільки він необхідний у всякому вчинку [10, с. 19]. Тож у цивільних взаєминах суб'єктивні права та обов'язки зазвичай формуються за волею їхніх носіїв. Відтак і встановлення тривалості теж визначається самими суб'єктами внаслідок виявлення своєї волі. Якщо ж контрагенти не погодили строків відповідної взаємодії, використовуються темпоральні критерії чинності їхніх прав та обов'язків, закріплені в законі (так званий принцип застосування диспозитивних норм). I лише зрідка цивільне законодавство прибігає до імперативу під час регулювання тривалості суспільних взаємин. Вольовий характер строків, що встановлюються самими учасниками цивільних матеріальних правовідносин або компетентними правозастосовними органами, не викликає сумнівів. Як результат вольових та усвідомлених юридичних дій суб'єктів права строки несуть на собі відбиток суб'єктивного, але, якщо їх встановлено, вони існують вже об'єктивно.

Строк - це певний відрізок у часі. Разом із тим час рухається у просторі і не може уявлятися без нього. Відтак роздуми про конкретний проміжок часу мають сенс лише по відношенню до того предмету, початок та закінчення якого він визначає. Інакше кажучи, поза простором певного явища строк позбавляється усілякої визначеності. Отже, юридичний строк - це об'єктивно існуюча залежність між явищами правового порядку, яка проявляється як певна кількість якісних змін юридичних явищ, виражена у величинах календарного часу, що протікають в певній послідовності зі змінами, зумовленими впливом даних явищ одне на одного, та така, що відображається у людській свідомості у вигляді певного числа годин, діб та інш. [11, с. 25]. Слід погодитися з характеристикою строків, наданою B.B. Луцьом: цивільно-правові строки $€$ часовою формою руху матеріальних правовідносин, формою існування та розвитку суб'єктивних прав та обов'язків, що становлять їхній зміст. Настання чи сплив строку має значення не само 
по собі, а лише в сукупності з діями суб'єктів, вчиненими упродовж його перебігу. Наприклад, пропуск позовної давності тягне відмову в позові не просто тому, що сплив даний строк, а тому, що позивач упродовж його тривалості не пред'явив позову про захист порушеного права [12, с. 40].

Форми використання часових критеріїв у матеріальних взаєминах обираються різні. Але безспірним $€$ той факт, що від влучного вибору та обгрунтованого встановлення темпорального компоненту залежить ефеектиність правового регулювання в цілому [13, с. 171]. Сучасне суспільство все більше досягає належного рівня усвідомлення того факту, що право $є$ засобом досягнення стабільності та визначеності соціальних взаємин. Воно має бути спрямоване на врахування взаємних інтересів учасників правовідносин, зокрема у сфері матеріального обороту. У цьому контексті одним із визначальних напрямків розвитку права $є$ регламентація строків, упродовж яких суб'єкти можуть здійснювати належні їм цивільні права та обов'язки, захищати порушене право. Адекватні реальним відносинам та виважені підходи у встановленні тривалості взаємин сприяють стабільності цивільного обороту, усуненню невизначеності стосовно повноважень та обов'язків його учасників у темпоральному плані, гарантують можливість своєчасного отримання правового захисту. Отже, строки забезпечують зміцнення договірної дисципліни, стимулюють активність контрагентів у цивільних відносинах при здійсненні ними своїх суб'єктивних прав та юридичних обов'язків, гарантують контроль за виконанням зобов'язань.

Багатоманітність зобов'язальних майнових відносин та особливості їхнього протікання у часі вимагають певної класифікації цивільно-правових строків, що опосередковують ті чи інші взаємини, визначають час реалізації належного особі суб'єктивного права та виконання юридичного обов'язку, які входять до змісту матеріального зобов'язання. При цьому мають враховуватися темпоральні характеристики не лише регулятивного зобов'язального відношення, а й охоронного, яке виникає після порушення суб'єктивного права. Часові характеристики існування та реалізації охоронних повноважень їхнього носія, у тому числі і матеріального права на позов (домагання), є дуже важливими та актуальними. Це надає можливість правильно оцінити юридичну природу, значення та місце строків у процесі набуття, реалізації та захисту суб'єктивних цивільних прав. На жаль, наукове дослідження строків захисту порушених суб'єктивних прав особи, переважно зводиться до аналізу виникнення, реалізації та припинення лише одного із захисних механізмів - позовного домагання. Між тим, охоронні правовідношення, що виникають внаслідок порушення регулятивного матеріального права особи, можуть реалі- зовуватися і у позасудовий спосіб. Мусимо констатувати, що серйозних наукових досліджень темпоральних ознак даного питання в цивілістичній літературі не проводилося. Із методологічної точки зору із цим важко погодитися. Значною мірою це пояснюється недооцінкою гостроти проблеми чи навіть нерозумінням важливості відповідних цивільних відносин. Саме тому багато років механізм застосування оперативних способів впливу на правопорушника регулювався судовою практикою, яка, у свою чергу, досить обережно та часто неоднозначно відображала застосування таких заходів, у тому числі і у темпоральному вимірі.

Законодавець, визначаючи темпоральні чинники тих чи інших зобов'язальних матеріальних взаємин, часто вказує на належність їх здійснення, яке має проявлятися у своєчасності виконання зобов'язання. Однак закон припускає, що тривалість певного правовідношення може бути невизначеною, якщо то не суперечить самій сутності зобов'язання. Відтак найбільш поширеним щодо строків, тривалість яких прямо не встановлена, є термін «розумний». Для вітчизняного законодавства подібний підхід до вирішення питання досить симптоматичний. Поняття розумності, як і добросовісності та справедливості, $є$ одними із засадничих принципів організації цивільно-правових відносин (ст. 3 ЦКУ). Але саме розумність більшою мірою застосовується для характеристики певних проявів належної поведінки у часі. Вона означає, що тривалість юридичних відносин має встановлюватися з огляду на розсудливість учасників, їхній здоровий глузд, доцільність та усвідомлене оперування поняттями, спираючись на природу та зміст опосередковуваних явищ.

Власне, розумний строк відноситься до категорії визначених, але його визначеність проявляється не в нормативних приписах чи в узгодженні сторін, а визначається, виходячи зі звичаїв ділового обороту, аналогії тощо, тобто $€$ звичною тривалістю для подібних взаємин на території, де вони відбуваються. Розумний строк - мінімально необхідний проміжок часу для виконання боржником свого обов'язку або реалізації суб'єктивного права активними діями кредитора за конкретних обставин, що склалися в певному правовідношенні. Життя показує, що в даному контексті розвиток правової ідеології спрямований від максимального юридичного позитивізму до все більш широкого судового розсуду. Справді, лише судова практика випрацьовує критерії розумності, добросовісності та справедливості поведінки учасників матеріально обороту. Однак для уникнення можливих різнобачень у даному питанні слід час від часу здійснювати узагальнення правозастосовних напрацювань у даній царині.

Можемо дійти певних висновків. Будучи офрормленими як правовідносини, конкретні взаємини 
в суспільстві переходять до сорери регулювання юридичними механізмами. Отже, при конструюванні конкретних матеріальних взаємодій сторони правочинів, визначаючи їхній зміст, враховують темпоральні критерії відповідних суб'єктивних прав та обов'язків, найбільш адекватних власним приватним чи суспільним (у разі встановлення строків законодавцем) потребам. А ці потреби якраз і можуть визначатися з урахуванням чинника соціального часу. Отже, можемо погодитися з висловленою в літературі думкою, що поняття соціального часу не охоплюється тільки змістом суспільної діяльності людини. Воно включає також і весь обсяг технічних та організаційних заходів, усього зробленого особою для економії часу чи для розширення творчих можливостей [14, с. 18].

\section{Список використаних джерел:}

1. Барковская А.Ю. Социологическая интерпретация категории «социальное пространство». Вестник Волгоградского государственного университета. Сер. 7. Филос. 2013. № 1(19). С. 49-55.

2. Sorokin P., Merton R. Social time. A methodological and functional analysis. American Journal of Sociology. 1937. № 5 (V. 42). 649 p.

3. Зборовский Е.И. Пространство и время как формы социального бытия. Свердловск, 1974. 184 с.

4. Ковалев В.И. Личностное время как предмет психологического исследования. Психология личности и время. Тезисы докл. и сообщ. Всесоюзной научно-теоретической конф. Черновцы, 1991. Т. 1. С. 4-8.

5. Луць В.В. Строки і терміни у цивільному праві : монографія. Київ : Юрінком Інтер, 2013. 320 с.

6. Головаха Е.И., Кроник А.А. Понятие психологического времени. Категории материалистической диалектики в психологии / Под ред. Л.И. Анциферовой. Москва : Наука, 1988. С. 199-234.

7. Савиньи Ф.К. фон. Система современного римского права. Т. I / Пер. с нем. Г. Жигулина ; Под ред. О. Кутателадзе, В. Зубаря. Москва : Статут, 2011. 510 с.

8. Гуйван П.Д. Теоретичні питання строків у приватному праві : монографія. Харків : Право, 2014. 632 с.

9. Лебедева К.Ю. Исковая давность в системе гражданско-правовых сроков : дисс. ... канд. юрид. наук. Томск, 2003. $243 \mathrm{c}$.

10. Азімов Ч.Н. Поняття цивільних правовідносин. Вісник університету внутрішніх справ. 1999. Вип. 6. C. $18-22$.

11. Щербаков О.В. Понятие юридического срока и его процессуальный режим. Проблемы совершенствования законодательства Украины и практика его применения: краткие тезисы докладов и научных сообщений межрегион. науч. конф. молодых ученых и соискат. Харьков : УЮА, 1991. С. 24-26.

12. Луць В.В. Сроки в гражданских правоотношениях. Правоведение. 1989. № 1. С. 37-43.

13. Шовкова О.В. Строки і терміни як категоріїцивільного права. Проблемизаконності. 2005. Вип. 74. С. $171-176$.

14. Артемов В. Социальное время: предвидение, исследовательски-прикладная и планово-управленческая практика. Телескоп: Журнал социологических и маркетинговых исследований. 2008. № 5. С. 15-20. 
УДК 347.633

DOI https://doi.org/10.37687/2413-6433.2020-1.5

\author{
Деркач I.M., \\ здобувач Навчально-наукового інституту права \\ Університету державної фіскальної служби України \\ ORCID: 0000-0003-1332-1666 \\ Дяченко С.В., \\ кандидат юридичних наук, доцент, \\ доцент кафедри цивільного права та процесу \\ Університету державної фіскальної служби України \\ ORCID: 0000-0002-0104-2769
}

\title{
ЗВЕРНЕННЯ СТЯГНЕННЯ НА МАЙНО, ПЕРЕДАНЕ В ІПОТЕКУ
}

\section{THE FORECLOSURE ON THE SUBJECT OF A MORTGAGE}

Стаття присвячена дослідженню іпотечних правовідносин, а саме зверненню стягнення на майно, передане в іпотеку. Дане питання є важливим з огляду на те, що спори даної категорії справ є досить проблемними, а судова практика щодо їх вирішення є мінливою, позиції різних судів в окремих випадках є неоднозначними, для кредиторів та боржників існує великий перелік проблем. Усе це призводить до створення складнощів у зверненні стягнення на предмет іпотеки. У роботі наведено аналіз судової практики стосовно спорів, які виникають щодо іпотеки, також наведені окремі роз'яснення Верховного Суду України, який своїми постановами врегулював проблемні питання, що виникали під час розгляду та вирішення таких справ.

Досліджені аспекти є актуальними, адже є велика кількість таких спорів за даними Єдиного державного реєстру судових рішень України, що свідчить про те, що існують проблеми, які потребують вивчення.

Було з' ясовано, що розгляд та вирішення іпотечних спорів має відповідати загальним засадам цивільного судочинства, зокрема й принципу диспозитивності, що є важливим з огляду на те, що в судовій практиці існують порушення даного принципу, і іпотечні спори не є винятком. Актуальним питанням в розрізі судової практики є питання співвідношення принципу диспозитивності та принципу ініціативності (активності, контролю) суду.

У роботі наведені та проаналізовані підстави для звернення стягнення на предмет іпотеки. Розглянуті проблеми, що можуть виникати в правозастосовній діяльності нотаріусів при вчиненні ними виконавчих написів за договорами іпотеки, які стосуються документів, які підтверджують безспірність вимог кредиторів та право на звернення стягнення на об’єкт нерухомості, порядку, строків, а також процедури звернення стягнення на предмет іпотеки.

На підставі проведених досліджень слід зазначити, що лише деякі проаналізовані під час написання даної роботи спірні питання судової практики щодо іпотечних спорів свідчать про те, що єдність судової практики в цій категорії справ ще не на належному рівні, і це вимагає від судів правильного розуміння та застосування закону з метою ухвалення справедливого, обгрунтованого та законного судового рішення.

Ключові слова: іпотека, звернення стягнення на предмет іпотеки, іпотечні спори, задоволення вимог іпотекодержателя, предмет іпотеки, іпотечні правовідносини.

The article is devoted to the study of mortgage legal relations, namely: the application of foreclosure on the mortgage. This issue is important given that the disputes in this category of cases are quite problematic, and the jurisprudence to resolve them is variable, the positions of the various courts in individual cases are ambiguous, and there is a wide range of problems for creditors and debtors. All this leads to difficulties in applying for a mortgage. The paper provides an analysis of case law on disputes arising out of a mortgage, and provides some clarifications of the Supreme Court of Ukraine, which by its decisions settled the problematic issues that arose during the consideration and resolution of such cases.

The investigated aspects are relevant, as there are a large number of such disputes according to the Unified State Register of Judgments of Ukraine, which indicates that there are problems that need to be studied.

It has been found that the consideration and resolution of mortgage disputes must be consistent with the general principles of civil litigation, including the principle of disposition, which is important in the light of the breach of this principle and that mortgage disputes are no exception. A topical issue in the context of jurisprudence is the relationship between the principle of disposition and the principle of initiative (activity, control) of the court.

The paper presents and analyzes the grounds for the recovery of the mortgage. The problems, which may arise in the law enforcement activity of notaries in the execution of their writs under the mortgage agreements, 
which relate to documents confirming the indisputable claims of creditors and the right to recover the property, procedure, terms, as well as the procedure for recovering the subject of recovery mortgages.

Based on the research, it should be noted that only some of the controversial issues of mortgage litigation in the course of writing this work indicate that the uniformity of jurisprudence in this category of cases is not yet adequate, and this requires the courts to have a proper understanding and the application of law in order to reach a fair, justified and lawful judgment.

Key words: mortgage, foreclose on the mortgage, mortgage disputes, satisfaction of mortgagee, mortgage subject, mortgage legal relations.

Вступ. Іпотека $€$ важливим інструментом фрінансування житлового будівництва та важливою інвестиційною складовою розвитку економіки України. Громадяни все частіше звертаються до банків, щоб оформити кредит чи іпотеку, водночас складне матеріальне становище українців, що зумовлене спадом економіки, великі відсотки за іпотечними договорами, недостатня проінформованість та обізнаність громадян щодо умов договору, коливання валютного курсу, збройна агресія Росії, а також інші фактори призводять до масових невиплат за кредитами. Усе це призводить до того, що зростає кількість звернень стягнення на предмет іпотеки згідно з договором про задоволення вимог іпотекодержателя, що здійснюється на підставі статей 12 і 33 Закону України «Про іпотеку», якими передбачено спосіб захисту прав та інтересів - звернення стягнення на предмет іпотеки.

Захищеність сторін - дуже важлива складова частина іпотечних правовідносин. У статті розглянуто поширені проблемні аспекти у зверненні стягнення на предмет іпотеки. Адже, як показує судова практика 3 даної категорії спорів, іноді грамотного оформлення іпотечного договору може бути недостатньо для задоволення вимог.

Незважаючи на те, що науковці традиційно приділяли значну увагу дослідженню іпотечних правовідносин та інституту іпотеки, звернення стягнення на предмет іпотеки й способи такого звернення залишаються недостатньо дослідженими, норми Закону України «Про іпотеку» щодо позасудового врегулювання звернення стягнення на предмет іпотеки $є$ недосконалими, внаслідок чого застосування таких способів на практиці в Україні ускладнено. У зв'язку із цим норми Закону України «Про іпотеку» і на цей час привертають увагу науковців та практиків.

Метою роботи $€$ аналіз судової практики щодо іпотечних спорів, з'ясування питання щодо звернення стягнення на майно, передане в іпотеку, дослідження окремих аспектів іпотечного зобов'язання та з'ясування можливих правових наслідків порушення зобов'язання за іпотечним договором, дослідження способів захисту прав та інтересів при вирішенні таких спорів, а також аналіз помилок, які допускають сторони даної категорії спорів та визначення способів їх усунення.

Матеріали та методи. При написанні роботи були використані загальнонаукові та спеціальні методи пізнання правових явищ, зокрема: діалектичний (що дозволив дослідити зв'язок суспільних явищ і процесів у сфері іпотеки, а також відповідних явищ у їх розвитку), системно-структурний метод, структурно-фрункціональний (при використанні якого досліджено функціональні особливості іпотеки), аналізу та синтезу, формально-логічний, або логіко-юридичний (при аргументації наукових висновків). Також використано такий спосіб наукового пізнання, як систематизація. Матеріалами дослідження є: нормативно-правові акти, праці вчених з даної тематики та постанови Верховного Суду України.

Дослідженню окремих аспектів іпотечних правовідносин, зокрема й зверненню стягнення на предмет іпотеки, а також принципів цивільного судочинства присвячені роботи таких вчених, як А.Ю. Бабаскіна, О.Ф. Дучал, С.В. Дяченка, Ю.І. Корнієнка, Ю.Ю. Рябченка та інших.

Результати. Стаття 1 Закону України «Про іпотеку» містить визначення поняття «іпотека», згідно з якою «іпотека - вид забезпечення виконання зобов'язання нерухомим майном, що залишається у володінні і користуванні іпотекодавця, згідно з яким іпотекодержатель має право в разі невиконання боржником забезпеченого іпотекою зобов'язання одержати задоволення своїх вимог за рахунок предмета іпотеки переважно перед іншими кредиторами цього боржника у порядку, встановленому цим Законом» [1].

Так, стаття 12 Закону України «Про іпотеку» містить положення про те, що: «У разі порушення іпотекодавцем обов'язків, встановлених іпотечним договором, іпотекодержатель має право вимагати дострокового виконання основного зобов'язання, а в разі його невиконання - звернути стягнення на предмет іпотеки, якщо інше не передбачено законом». Згідно зі статтею 33 наведеного вище Закону, «у разі невиконання або неналежного виконання боржником основного зобов'язання іпотекодержатель вправі задовольнити свої вимоги за основним зобов'язанням шляхом звернення стягнення на предмет іпотеки, якщо інше не передбачено законом» [1].

Цивільний кодекс України містить норму, згідно з якою кожна особа має право на звернення до суду з метою захисту свого особистого немайнового або майнового права та інтересу. Ним також визначено судові способи захисту цивільного права чи інтересу, що передбачено 
статтею 16 Цивільного кодексу України, згідно з нормами якої звернення стягнення на предмет іпотеки може здійснюватись на підставі рішення суду та позасудових способів захисту цивільного права чи інтересу, положення про які містяться в статтях 17-19 Цивільного кодексу України, до яких необхідно віднести: захист прав нотаріусом (що полягає у зверненні стягнення на предмет іпотеки на підставі виконавчого напису нотаріуса), а також самозахист (що полягає в можливості звернення стягнення на предмет іпотеки згідно з договором про задоволення вимог іпотекодержателя) [2].

Статтею 33 Закону України «Про іпотеку» закріплено підстави для звернення стягнення на предмет іпотеки: «Звернення стягнення на предмет іпотеки здійснюється на підставі рішення суду, виконавчого напису нотаріуса або згідно з договором про задоволення вимог іпотекодержателя. Звернення стягнення на майно $€$ предметом іпотеки і належить державному чи комунальному підприємству або підприємству, більш як 50 відсотків акцій (часток, паїв) якого перебуває у державній власності, здійснюється на підставі рішення суду» [1].

Розгляд та вирішення іпотечних спорів має відповідати загальним засадам цивільного судочинства. Зокрема, й принципу диспозитивності, який закріплений у статті 13 Цивільного процесуального кодексу України, відповідно до якого: «Суд розглядає справи не інакше як за зверненням особи, поданим відповідно до цього Кодексу, в межах заявлених нею вимог і на підставі доказів, поданих учасниками справи або витребуваних судом у передбачених цим Кодексом випадках. Учасник справи розпоряджається своїми правами щодо предмета спору на власний розсуд. Таке право мають також особи, в інтересах яких заявлено вимоги, за винятком тих осіб, які не мають процесуальної дієздатності» [3].

Як зазначають деякі науковці, «суть диспозитивності полягає в тому, що сторони судового процесу (учасники процесу з обох сторін) вільно розпоряджаються своїми матеріальними та процесуальними правами, реалізація яких із метою захисту своїх прав та охоронюваних законом інтересів має безпосередній вплив на виникнення, динаміку чи закінчення судового процесу» [4, с. 116].

Переконливим аргументом визначальної ролі принципу диспозитивності в цивільному процесуальному праві є відсутність законодавчо закріпленого права суду відмовити позивачу чи його представнику у прийнятті заяви про залишення позову без розгляду чи відмови від позову в разі, якщо така відмова від подальшого судового розгляду спору суперечить або ж не узгоджується з правами, свободами чи інтересами позивача або інших осіб. Принцип диспозитивності в іпотечних спорах застосовується, наприклад, під час обрання порядку звернення стягнення на предмет іпотеки, що залежно від волі іпотекодержателя може бути як судовим, так і позасудовим.

Верховний Суд України у своїй постанові від 15 серпня 2018 року у справі № 2-823/11 зазначає: «Для реалізації іпотекодержателем позасудового способу звернення стягнення на предмет іпотеки шляхом визнання права власності на нього за загальним правилом необхідні тільки воля та вчинення дій з боку іпотекодержателя, якщо договором не передбачено іншого порядку» [5].

Таким чином, передача іпотекодержателю права власності на предмет іпотеки відповідно до статей 36, 37 Закону України «Про іпотеку» $€$ способом позасудового врегулювання, який здійснюється за згодою сторін без звернення до суду. Застереження в договорі про задоволення вимог іпотекодержателя шляхом визнання права власності на предмет іпотеки - це виключно позасудовий спосіб урегулювання спору, який сторони можуть встановити самостійно в договорі, оскільки, з урахуванням вимог статей 328 , 335, 392 Цивільного кодексу України у контексті статей 36, 37 Закону України «Про іпотеку», суди не наділені повноваженнями звертати стягнення на предмет іпотеки шляхом визнання права власності на нього за іпотекодержателем.

Актуальним питанням в розрізі судової практики є питання співвідношення принципу диспозитивності, який можна визначити як свободу сторін щодо розпорядження їхніми матеріальними та процесуальними правами, та принципу ініціативності (активності, контролю) суду.

До таких контрольних функцій можна віднести те, що при отриманні позовних заяв з вимогами про звернення стягнення на предмет іпотеки судді вирішують питання про залишення позовної заяви без руху й пропонують позивачу усунути недоліки, які стосуються відповідності змісту позовної заяви вимогам законодавства, зокрема й Закону України «Про іпотеку». Також сюди можна віднести і те, що суд має право не прийняти відмову від позову, а також не затвердити мирову угоду сторін у справі, якщо особу в даній справі представляє її законний представник, дії якого суперечать інтересам тієї особи, яку він власне і представляє та/ або якщо визнання відповідачем позову або умов мирової угоди суперечить закону та/або порушує права, свободи чи інтереси інших осіб - у таких випадках суд постановляє ухвалу про відмову у прийнятті визнання відповідачем позову чи ухвалу про відмову у визнанні мирової угоди і продовжує судовий розгляд.

Як приклад активної ролі суду можна навести також його право на залучення до участі у справі третіх осіб, які не заявляють самостійних вимог на предмет спору, але лише в тому випадку, якщо суд при прийнятті позовної заяви або здійсненні провадження у справі виявить, що дане судове рішення може вплинути на 
права і обов'язки осіб, які не є стороною у справі відповідно до статті 53 Цивільного процесуального кодексу України.

Активність суду має прояв також в обов'язку головуючого судді усувати із судового розгляду все, що не має істотного значення для вирішення справи, як-то, наприклад, відхиляти клопотання сторін, що не стосуються предмету доказування відповідно до статті 160 Цивільного процесуального кодексу України.

У справі № 220/421/17 судами різних інстанцій розглядався спір за позовом про визнання права власності за іпотечним договором та зняття з майна арешту, а також за зустрічним позовом про визнання договору неукладеним через те, що спільне майно було передано в заставу без згоди другого з подружжя. При розгляді справи суд встановив, що договір іпотеки укладено між сторонами після того, як щодо іпотекодавця було постановлено рішення про стягнення заборгованості. Позивач за зустрічним позовом стверджував, що договір позики $€$ удаваним, який фактично не укладався, його підписано лише з метою уникнення примусового стягнення грошових коштів на користь цього позивача. Суд першої інстанції та апеляційний суд відмовили у задоволенні і первісного позову, і зустрічного, але їхня мотивація відрізнялась. Переглядаючи справу, Велика Палата Верховного Суду у своїй постанові від 27 березня 2019 року у цій справі № 220/421/17 наведела такий висновок: «У зустрічному позові ПП «Рондо» не посилалося на фіктивність договору іпотеки. Суд апеляційної інстанції, застосувавши статтю 234 Цивільного кодексу України i, визнавши договір іпотеки фіктивним, порушив вимоги статті 13 Цивільного процесуального кодексу України, у якій закріплено принцип диспозитивності, за яким право визначати підставу позову належить позивачу» [6].

Важливим, при вирішенні іпотечних спорів в суді, $є$ дотримання сторонами принципу змагальності, рівності та пропорційності. Як зауважують науковці: «Змагальність у судовому процесі вимагає, щоб суб'єкти обвинувачення й захисту, цивільний позивач і цивільний відповідач мали однакову можливість переконати суд у своїй правоті. Суду належить керівна роль у судовому розгляді, він сприяє повному, всебічному з'ясуванню обставин справи і виносить рішення на підставі внутрішнього переконання, керуючись законом» [7, с. 107].

Ще одним з основних принципів вирішенні іпотечних спорів в суді $\epsilon$ принцип рівності перед судом, який вважають основою сучасної концепції справедливого правосуддя. Європейський суд з прав людини досить часто посилається на принцип рівності перед законом і судом у своїх рішеннях, при тому, що засади рівності і змагальності у судовому процесі виведені ним із принципу верховенства права [8, с. 93].
Слід відмітити також принцип пропорційності у цивільному судочинстві при вирішенні іпотечних спорів в суді, який, за своєю суттю, забезпечує реалізацію найбільш доцільних прав та обов'язків іподекодавця та іпотекодержателя під час розгляду іпотечного спору в суді [9, с. 93].

Обговорення. Досліджуючи роботи вчених на тематику даної роботи, варто відзначити А.Ю. Бабаскіна, який у своїй праці «Проблеми звернення стягнення на предмет іпотеки в порядку позасудового врегулювання» вказував таке: «Аналізуючи порядок позасудового врегулювання та порядок державної реєстрації права власності іпотекодержателя на предмет іпотеки можна зробити висновок щодо порядку, в якому має здійснюватися таке звернення стягнення на предмет іпотеки: а) звернення стягнення на предмет іпотеки в порядку позасудового врегулювання відстрочується на тридцять днів з дати отримання іпотекодавцем та боржником, якщо він $€$ відмінним від іпотекодавця, письмової вимоги іпотекодержателя; б) для здійснення державної реєстрації речових прав на нерухоме майно іпотекодержатель має надати державному реєстратору, визначенні законодавством документи, зокрема документ, що підтверджує фракт отримання іпотекодавцем та боржником, якщо він відмінний від іпотекодавця, письмової вимоги іпотекодержателя та сплив тридцятиденного строку з моменту ії̈ отримання вказаними особами» [10, с. 146].

Також необхідно зазначити, що перешкодою для швидкого вирішення даних спорів, які стосуються звернення стягнення на предмет іпотеки, $\epsilon$ те, що необхідно визначити початкову ціну реалізації майна, переданого в іпотеку.

Попередня правова позиція вищих судів містила положення про те, що, як обов'язковий компонент судового рішення щодо звернення стягнення на предмет іпотеки, має бути зазначена початкова ціна реалізації предмету іпотеки, що включало в себе і вимоги для проведення прилюдних торги. Також зазначалось, що ціну реалізації майна, переданого в іпотеку, має встановлюватись на рівні, що не $є$ нижчим за звичайні ціни, які встановлюються на такий вид майна, і бути належним чином визначеною суб'єктом оціночної діяльності за відповідною методикою та правилами.

Наразі Велика Палата Верховного Суду України постановою від 21 березня 2018 року у справі № 235/3619/15-ц визначила, що в іпотечних спорах у резолютивній частині судового рішення початкова ціна предмета іпотеки у грошовому вираженні не відіграє вирішального значення, оскільки у випадку ії не зазначення не настає, як наслідок, безумовне скасування судового рішення [11].

Верховний Суд своєю постановою від 27 червня 2018 року у справі № 372/3785/15-ц вказав на те, що суд правомірно визначає почат- 
кову ціну предмета іпотеки з метою його подальшої реалізації на тому рівні, який не нижче від звичайної ціни на даний вид майна, на підставі проведеної суб'єктом оціночної діяльності чи незалежним експертом оцінки майна, коли проводяться виконавчі дії [12].

Згідно зі статтями 12, 33 та 35 Закону України «Про іпотеку» варто зазначити, що підставами звернення стягнення на предмет іпотеки є: 1) порушення умов договору іпотеки, 2) порушення умов збереження та страхування предмету іпотеки, 3) порушення умов основного договору, 4) банкрутство або ліквідація юридичної особи [1].

При розгляді звернення стягнення на предмет іпотеки, що здійснюється на підставі рішення суду, можна виділити такі способи задоволення вимог іпотекодержателя: 1) реалізацію предмета іпотеки, що здійснюється проведенням прилюдних торгів, що передбачено статтями 41-47 Закону України «Про іпотеку»; 2) право на продаж предмета іпотеки іпотекодержателем покупцеві, який може бути будь-яким, що закріплено у статті 38, наведеного вище Закону.

3 огляду на це існують проблемні питання звернення стягнення на предмет іпотеки, серед яких можна виокремити зловживання виконавців чи організаторів публічних торгів на стадії, коли здійснюється організація та проводяться публічні торги, помилки під час них, а також порушення стосовно письмових повідомлень зацікавлених осіб, зокрема іпотекодавця про проведення даних торгів, їх дату, місце, час та початкову оцінку майна, направлення актів про реалізацію предмета іпотеки, копій протоколів про результати проведення публічних торгів тощо.

Труднощі у зверненні стягнення можуть полягати в тому, що опис предмета іпотеки за іпотечним договором не відповідатиме інвентаризаційним даним реконструйованого об'єкта. У зв'язку із цим державний реєстратор відмовить у реєстрації за іпотекодержателем права власності на предмет іпотеки навіть $y$ разі пред'явлення йому рішення суду про звернення стягнення на предмет іпотеки, яке вступило в законну силу [13, с. 113].

Щодо звернення стягнення на предмет іпотеки на підставі виконавчого напису нотаріуса, то варто зазначити, що вчинення виконавчого напису $є$ нотаріальною дією, спрямованою на надання документу виконавчої сили.

Ю.І. Корнієнко у своїй роботі «Цивільно-правове регулювання звернення стягнення на предмет іпотеки» зазначає: «Одним із проблемних моментів практики вчинення виконавчого напису на договорі іпотеки є врахування умов документів, що встановлюють таку заборгованість, тобто кредитних договорів, договорів позики. У більшості випадків умови таких договорів встановлюють обов'язок іпотекодавця (боржника) щодо повернення грошової суми частинами відповідно до графіка повернення боргу. У ситуації, коли кредитним договором встановлено графрік погашення заборгованості й має місце порушення боржником одного або кількох строків такого графіка, але кінцевий термін повернення заборгованості ще не настав, то окремими фахівцями ставиться під сумнів можливість вчинення виконавчого напису з тих підстав, що строк повернення заборгованості за договором у цілому ще не настав» [14, с. 74].

Відповідно до статті 42 Закону України «Про нотаріат»: «За обґрунтованою письмовою заявою заінтересованої особи, яка звернулася до суду та на підставі отриманого від суду повідомлення про надходження позовної заяви заінтересованої особи, яка оспорює право або фракт, про посвідчення якого просить інша заінтересована особа, вчинення нотаріальної дії зупиняється до вирішення справи судом» [15].

Тобто якщо іпотекодавець не звернувся до суду з оспорюванням права іпотеки або розміру заборгованості, а просто написав нотаріусу листа про те, що він проти вчинення виконавчого напису на договорі іпотеки, підстав для відмови іпотекодержателю у вчиненні виконавчого напису у нотаріуса немає [16, с. 88].

Згідно з пунктом 51 постанови Верховного Суду України від 29 серпня 2018 року у справі № 686/17779/16-ц: «У справах про оскарження рішень, дій чи бездіяльності нотаріуса, прийнятих або вчинених ним під час реалізації функцій державного реєстратора, якщо позовні вимоги спрямовані на захист заснованого на приписах цивільного чи господарського законодавства приватного (майнового) права у відносинах з іншими особами, нотаріус має залучатися до участі у справі як третя особа, яка не заявляє самостійних вимог на предмет спору» [17].

Висновки. Отже, варто виділити, що Цивільний кодекс України містить норму згідно з якою кожна особа має право на звернення до суду з метою захисту свого особистого немайнового або майнового права та інтересу. Ним також визначено судові способи захисту цивільного права чи інтересу, що передбачено статтею 16 Цивільного кодексу України , згідно з нормами якої звернення стягнення на предмет іпотеки може здійснюватися на підставі рішення суду та позасудові способи захисту цивільного права чи інтересу, положення про які містяться в статтях 17-19 Цивільного кодексу України, до яких необхідно віднести: захист прав нотаріусом (що полягає в зверненні стягнення на предмет іпотеки на підставі виконавчого напису нотаріуса), а також самозахист (що полягає в можливості звернення стягнення на предмет іпотеки згідно з договором про задоволення вимог іпотекодержателя).

Аналіз судової практики показує, що трапляються випадки порушення принципу диспозитивності під час вирішення іпотечних спорів, як наприклад, було визначено у наведеному 
прикладі по справі № 220/421/17 відповідно до якої позивач не послався у своєму позові на фріктивність, укладеного договору іпотеки, що порушило вказаний принцип цивільного судочинства, оскільки позивачу належить право визначати підставу позову.

Принцип диспозитивності в іпотечних спорах застосовується також під час обрання порядку звернення стягнення на предмет іпотеки, що, залежно від волі іпотекодержателя, може бути як судовим, так і позасудовим.

3 урахуванням наведеного в даній роботі в іпотечних спорах у резолютивній частині судового рішення початкова ціна предмета іпотеки у грошовому вираженні не відіграє вирішального значення, оскільки у випадку її незазначення не настає як наслідок безумовне скасування судового рішення. Суд правомірно визначає початкову ціну предмета іпотеки з метою його подальшої реалізації на тому рівні, який не нижче від звичайної ціни на даний вид майна, на підставі проведеної суб'єктом оціночної діяльності чи незалежним експертом оцінки майна, коли проводяться виконавчі дії.

Для реалізації іпотекодержателем позасудового способу звернення стягнення на предмет іпотеки шляхом визнання права власності на нього за загальним правилом необхідні тільки воля та вчинення дій з боку іпотекодержателя, якщо договором не передбачено іншого порядку.

\section{Список використаних джерел:}

1.Проіпотеку:Закон Українивід05.06.2003 p.№898-IV.Датаоновлення:21.10.2019.URL:https://zakon.rada.gov.ua/ laws/show/898-15 (дата звернення: 27.02.2020).

2. Цивільний кодекс України : Закон України від 16.01.2003 р. № 435-IV. Дата оновлення: 13.02.2020. URL : https://zakon.rada.gov.ua/laws/show/435-15 (дата звернення: 27.02.2020).

3. Цивільний процесуальний кодекс України : Закон України від 18.03.2004 p. № 1618-IV. Дата оновлення: 13.02.2020. URL : https://zakon.rada.gov.ua/laws/show/1618-15\#Text (дата звернення: 27.02.2020).

4. Дейнеко ОВ, Дяченко С. В. Імперативно-диспозитивний метод цивільного процесу як форма реалізації принципу диспозитивності. Науковий вісник публічного та приватного прав. Т. 1. 2019. Вип. № 4. С. 112-117. URL: https://doi.org/10.32844/2618-1258.2019.4-1.18 (дата звернення: 13.05.2020).

5. Постанова Верховного Суду України від 15 серпня 2018 р., судова справа № 2-823/11. URL : http://www.reyestr.court.gov.ua/Review/75969931 (дата звернення: 27.02.2020).

6. Постанова Верховного Суду України від 27 березня 2019 р., судова справа № 220/421/17. URL : http://www.reyestr.court.gov.ua/Review/81287762 (дата звернення: 27.02.2020).

7. Дяченко С.В., Гриценко М.О. Місце принципу змагальності в цивільному судочинстві. Журнал східноєвропейського права. 2019. № 69. С. 105-109. URL : https://doi.org/10.5281/zenodo.3555052 (дата звернення 13.05.2020).

8. Дяченко С.В., Пушкарьова Т.М. Принцип права на справедливий суд: елементи розгляду та практика Європейського суду з прав людини щодо України. Журнал східноєвропейського права. 2019. № 70. С. 90-96. URL : https://doi.org/10.5281/zenodo.3607996 (дата звернення 13.05.2020).

9. Арутюнян А.В., Сивко К.Р., Дяченко С.В. Принцип пропорційності в цивільному судочинстві, теоретичні аспекти та законодавче закріплення. Практичне застосування в цивільному процесі. Юридичний науковий електронний журнал. 2019. № 6. С. 90-94. URL : https://doi.org/10.32782/2524-0374/2019-6/19 (дата звернення: 13.05.2020)

10. Бабаскін А.Ю. Проблеми звернення стягнення на предмет іпотеки в порядку позасудового врегулювання. Держава і право. Юридичні і політичні науки. 2014. Вип. № 66. С. 142-148.

11. Постанова Верховного Суду України від 21 березня 2018 р., судова справа № 235/3619/15-ц. URL : http://reyestr.court.gov.ua/Review/73500804 (дата звернення: 27.02.2020).

12. Постанова Верховного Суду України від 27 червня 2018 р., судова справа № 372/3785/15-ц. URL : http://www.reyestr.court.gov.ua/Review/75215515 (дата звернення: 27.02.2020).

13. Дучал О.Ф. Захист прав сторін при звернені стягнення на предмет іпотеки за заставною. Порівняльноаналітичне право. 2015. № 3. С. 112-113.

14. Корнієнко Ю.І. Цивільно-правове регулювання звернення стягнення на предмет іпотеки. Приватне право і підприємниитво. 2011. № 10. С. 73-75.

15. Про нотаріат : Закон України від 02.09.1993 р. № 3425-XII. Дата оновлення: 13.02.2020. URL : https://zakon.rada.gov.ua/laws/show/3425-12 (дата звернення: 27.02.2020).

16. Первомайський О. Окремі питання вчинення виконавчого напису щодо нотаріально посвідчених договорів. Мала енциклопедія нотаріуса. Київ, 2007. № 1(31). С. 88-89.

17. Постанова Верховного Суду України від 29 серпня 2018 р., судова справа № 686/17779/16-ц. URL : http://www.reyestr.court.gov.ua/Review/78011431 (дата звернення: 27.02.2020). 
УДК 340

DOI https://doi.org/10.37687/2413-6433.2020-1.6

\author{
Костицький В.В., \\ доктор юридичних наук, професор, академік \\ Національної академії правових наук України \\ ORCID: 0000-0003-1692-9810
}

\title{
СОЦІОЛОГО-ПРАВОВА ЗУМОВЛЕНІСТЬ ПЛЮРАЛІСТИЧНОСТІ СУЧАСНОГО ПРАВОРОЗУМІННЯ
}

\section{SOCIOLOGICAL AND LEGAL CONDITIONALITY OF THE PLURALISM OF MODERN LEGAL UNDERSTANDING}

У статті автор продовжує дослідження проблем розвитку соціології права, в тому числі і в контексті проблем сучасного праворозуміння. Оскільки право в сучасному суспільстві залишається універсальним і найбільш ефективним регулятором суспільних відносин, інструментом формування влади і здійснення нею функцій держави, мірою рівності і справедливості, засобом унормування, реалізації та захисту прав і свобод людини, загострюється потреба у дослідженнях проблем праворозуміння. Зважаючи на домінування соціологічних підходів у вивченні правової реальності та права як соціального явища, автор зосереджується на окремих аспектах соціолого-правової зумовленості дослідження сучасного праворозуміння.

Особливості сучасного суспільного розвитку виключають можливість монопольного володіння на єдино вірну та незаперечну істину у сфері праворозуміння. Тому перед правознавством постали проблеми пошуку відповідей на виклики, зумовлені сучасними викликами розвитку. Адже поза соціумом право залишається «мертвим» текстом. Одним із важливих завдань сучасного правознавства автор вважає розвиток соціології права, соціолого-правових підходів у дослідженні проблем праворозуміння, оскільки сьогодні право як феномен суспільного розвитку не може бути визначене за допомогою методологічних підходів, запропонованих однією із сучасних теоретичних шкіл.

Ураховуючи наявну в юридичній науці множинність підходів до розуміння права, яка має об'єктивний характер, автор у такому плюралізмі вбачає дві тенденції: по-перше, множинність праворозуміння супроводжується протиборством провідних наукових шкіл і типів розуміння права. а своєрідним «двигуном» цієї дискусії є переконаність кожної зі шкіл в істинності «свого» напряму; по-друге, спостерігається криза праворозуміння, коли право взагалі починає розглядатися як феномен настільки складний i багатоаспектний, що жодна зі шкіл не може претендувати на формулювання якоїсь «істини в останній інстанції», тому у роботі звертається увага на досліджувані у рамках соціології права соціальні об’єктивні чинники плюралістичності типів праворозуміння (економічна ситуація в країні, політичне становище, вплив ідеологій у суспільстві, особливості історичного моменту, культури, менталітету, суспільної моралі, релігійних переконань та інших елементів соціального середовища, в умовах яких формуються та розвиваються певні типи праворозуміння). Різноманітні об'єктивні та суб'єктивні чинники плюралістичності праворозуміння часто переплітаються та взаємодіють між собою, їхня взаємодія може бути простежена також на буденному, фахово-юридичному та теоретико-правовому рівнях праворозуміння.

Ключові слова: праворозуміння, типологія праворозуміння, юспозитивізм і юснатуралізм.

In the article the author continues research of problems of development of sociology of law, including in the context of problems of modern legal understanding. As law in modern society remains a universal and most effective regulator of social relations, a tool for forming power and exercising state functions, a measure of equality and justice, a means of standardization, implementation and protection of human rights and freedoms, the need for research on legal issues. Given the dominance of sociological approaches in the study of legal reality and law as a social phenomenon, the author focuses on certain aspects of the socio-legal conditionality of the study of modern legal understanding.

Peculiarities of modern social development exclude the possibility of monopoly possession of the only true and indisputable truth in the field of legal understanding. Therefore, jurisprudence faced the problem of finding answers to the challenges posed by modern development challenges. After all, outside society, law remains a "dead" text. One of the important tasks of modern jurisprudence, the author considers the development of sociology of law, sociological and legal approaches to the study of legal understanding, because today law as a phenomenon of social development can not be defined using methodological approaches proposed by one of the modern theoretical schools.

Given the existing in legal science multiplicity of approaches to understanding law, which is objective in nature, the author sees two tendencies in this pluralism: first, the multiplicity of legal understanding is accompanied by the confrontation of leading scientific schools and types of understanding of law, and a kind 
of "engine" of this discussion is the conviction of each of the schools in the truth of "their" direction; secondly, there is a crisis of legal understanding, when law in general begins to be seen as a phenomenon so complex and multifaceted that none of the schools can claim to formulate some "truth in the last resort", so the paper draws attention to the study of sociology of social law active factors of pluralism of types of legal understanding (economic situation in the country, political situation, influence of ideologies in society, features of historical moment, culture, mentality, public morality, religious beliefs and other elements of social environment in which certain types of legal understanding are formed and developed). Various objective and subjective factors of pluralism of legal understanding are often intertwined and interact with each other, their interaction can also be traced at the everyday, professional-legal and theoretical-legal levels of legal understanding.

Key words: legal understanding, typology of legal understanding.

Постановка проблеми у загальному вигляді та її зв'язок з важливими практичними завданнями. Право в сучасному суспільстві залишається універсальним і найбільш есрективним регулятором суспільних відносин, інструментом формування влади і здійснення нею функцій держави, мірою рівності і справедливості, засобом унормування, реалізації та захисту прав і свобод людини. Разом із тим у динамічному світі право також швидко розвивається, що зумовлює потребу в науковому осмисленні місця і ролі права у житті соціуму, а тому і детермінує потребу у дослідженні сучасних проблем праворозуміння.

Аналіз останніх досліджень і публікацій. Виділення невирішених раніше аспектів загальної проблеми. На фоні окремих тверджень про кризу сучасного праворозуміння зберігають свою актуальність праці вчених, спрямованих на дослідження плюралістичності та типології праворозуміння, оскільки у визнанні права на власну наукову творчість у галузі права та множинності праворозуміння запорука поступального розвитку юридичної науки. Ці питання у фрілософрсько-правовому, соціолого-правовому та теоретико-правовому контексті висвітлювалися у працях С. Алєксєєва, Р. Ангера, Г.Дж. Бермана, Дж. Голла, М. Костицького, К. Ллевелліна В. Нерсесянца, К. Олівекрона, Р. Познера, П. Рабіновича, Дж. Френка, Ю. Шемшученка та інш. Узагальнення їх наукового доробку та спроби напрацювання інтегральних пояснень френомену права $€$ одним із важливих завдань правової науки.

Формування цілей статті. Основним завданням написання статті $\epsilon$ з'ясування сучасних гносеологічних проблем права. Зважаючи на домінування соціологічних підходів у вивченні правової реальності та права як соціального явища розглядається можливість виокремлення соціолого-правової зумовленості дослідження сучасного праворозуміння.

Виклад основного матеріалу. У сучасній науковій літературі зміст категорії «праворозуміння» розкривається найчастіше так: праворозуміння - це пізнання (осягнення, усвідомлення, осмислення) права, а то й всієї правової реальності, правового буття. При цьому предмет пізнання трактується по-різному. Одні автори обмежують такий предмет сутністю права та його роллю в регулюванні суспільних відносин, інші ж включають у нього майже всі загальні властивості, риси і прояви права, ототожнюючи праворозуміння майже з усім загальнотеоретичним правознавством [2]. Отже, предметом праворозуміння $€$ право як соціальне явище як у найбільш загальному вигляді, так і в конкретних його проявах. Так, зазначеним об'єктом може виступати як право в планетарному масштабі, право конкретного суспільства, галузь чи інститут права, його окремі норми.

У спеціальній літературі всі визначення праворозуміння охоплюють інтерпретацію цього поняття здебільшого або лише як процесу пізнання й пояснення права (вузькі тлумачення [4]), або ж як процесу і результату такого пізнання й пояснення із одночасним виробленням оцінки та ставлення суб'єкта пізнання права (широкі тлумачення [5]). Другий аспект пов'язаний з тим, що праворозуміння інтелектуальна діяльність, але одночасно складний емоційно-інтелуктуальний процес, що вбирає в себе й емоції, почуття, переживання з приводу чинного та бажаного права, які одночасно $є$ тим спонукальним чинником, який, стимулюючи свідомість, накопичений у ній правовий досвід, правові знання, навички та вміння, пробуджує у свідомості правові образи, що містять закономірні властивості права [7].

Звідси, поняття праворозуміння тісно пов'язане 3 поняттям правосвідомості. Зокрема, залежно від специфріки правосвідомості праворозуміння може бути доктринальним, буденним, науковим тощо. Тому праворозуміння - це емоційно-інтелектуальна діяльність, спрямована на системне пізнання й сприйняття сутності змісту права, його оцінки і вироблення ставлення до права як до цілісного соціального явища [6, с. 16], а також сукупність нагромаджених правових знань. Йдеться про процес і результат пізнання найважливіших проявів буття права, його сутнісних характеристик, що надають змогу відмежувати його від інших соціальних феноменів, насамперед інших соціальних регуляторів релігії, моралі, звичаїв, корпоративних та політичних норм тощо. Відповідно, виокремлюють чотири ключові форми (ознаки) праворозуміння: 1) пізнання права; 2) сприйняття права; 3) оцінка права; 4) ставлення до права.

Вище ми вже згадали про існуючу в науці множинність підходів до розуміння права, яка 
має об'єктивний характер. У такому плюралізмі вбачаються дві тенденції. Перша з них полягає в тому, що множинність праворозуміння супроводжується протиборством провідних наукових шкіл і типів розуміння права. Своєрідним «двигуном» цієї дискусії $€$ переконаність кожної зі шкіл в істинності «свого» напряму. Друга тенденція пов'язується з кризою праворозуміння, коли право взагалі починає розглядатися як феномен настільки складний і багатоаспектний, що жодна зі шкіл не може претендувати на формулювання якоїсь «істини в останній інстанції». Об'єктивними чинниками плюралістичності типів праворозуміння $€$ економічна ситуація в країні, політичне становище, вплив ідеологій у суспільстві, особливості історичного моменту, культури, менталітету, суспільної моралі, релігійних переконань та інших елементів соціального середовища, в умовах яких формуються та розвиваються певні типи праворозуміння. Різноманітні об'єктивні та суб'єктивні чинники плюралістичності праворозуміння часто переплітаються та взаємодіють між собою, їхня взаємодія може бути простежена також на буденному, фахово-юридичному та теоретико-правовому рівнях праворозуміння.

Для окреслення різних підходів до розуміння права вживають поняття типу праворозуміння, яке позначає собою філософсько-юридичний або теоретико-методологічний підхід обґрунтування загального поняття права, закономірностей його походження, сутності, фрорм вираження та співвідношення права з державою [8, с. 37]. Таке поняття використовують здебільшого для наукової ідентифікації, зокрема для віднесення правового вчення до певного типу праворозуміння. Отже, типологія у праворозумінні має чітко визначні ідентифрікаційні цілі: кожне вчення можна, з певним ступнем умовності, віднести до того чи іншого типу праворозуміння. Важливість такої типології чітко уловлена проф. В. Нерсесянцом: «Тип праворозуміння визначає парадигму (смислову модель, принцип і взірець) юридичного пізнання, власне науково-правовий зміст, предмет і метод відповідного вчення про право [9].

У сучасній теорії права досі немає єдиної усталеної та загальновживаної класифікації типів праворозуміння. Виокремлюють два найбільш великі - позитивістський та непозитивістський типи праворозуміння [10]. В. Нерсесянц, В. Четвернін та Г. Лук'янова вважають, що існує три основних типи розуміння права: легістський (позитивістський), природно-правовий (юснатуралістичний) і лібертарно-юридичний $[11$, с. 36]. В О. Скакун це позитивістський, непозитивістський (природно-правовий) та змішаний (інтегративний) типи праворозуміння [12], а у М.І. Козюбри та О. Піщуліна - природно-правовий (юснатуралістичний), юридико-позитивістський (нормативістський) і соціологічний типи праворозуміння [13, с. 35].
О. Мартишин виділив чотири типи праворозуміння: юридичний позитивізм (нормативізм), соціологічний позитивізм, теорії природного права і фрілософрське розуміння права, але, окрім цих класичних підходів, ще й похідний від них - інтегративний, заснований на поєднанні в різному співвідношенні принципів, що лежать в основі перших чотирьох підходів [14]. Зауважимо, що часто у таких типологіях не визначаються критерії класифікації. Так, Г. Бернацький розрізняє теологічний, натуралістичний, об'єктивно-ідеалістичний, суб'єктивно-ідеалістичний, містичний, економічний, політологічний, соціальний, формально-догматичний типи [15], а П. Баранов, вважаючи таким критерієм суб'єкт нормоутворення, поділяє праворозуміння на теологічне, природно-правове, історичне, позитивно-правове [17]. Оскільки за кожним видом можемо побачити кілька різних суб'єктів, які можуть повторюватися і в інших випадках, вважаємо такий вибір критеріїв невдалим.

Також не охоплює усіх можливих видів використання двох підстав для класифікації типів праворозуміння (практичної і теоретичної) A. Поляковим [18]. Практичний тип праворозуміння відображається в суспільній правовій свідомості у вигляді найбільш загальних ознак, що характеризують ставлення суспільства до права, його особливе правознавство та почуття з приводу права. Але тоді визнати, що не тільки кожна цивілізація, але й кожна культура, кожна країна і соціальна група та й зрештою кожна людина має є свій тип праворозуміння. Можна виокремити загальні типи, наприклад, праворозуміння Сходу і Заходу (незахідних та західної цивілізацій), а також національні, групові та індивідуальні типи праворозуміння. Погодимося, що теоретичне праворозуміння може бути оформлено концептуально, якщо взяти до уваги запропоновані А. Поляковим три теоретичні підходи до розуміння права: природно-правовий, етатистський і соціологічний. Але це не виключає того, що теоретичне праворозуміння може мати місце на рівні правової ідеології як виду правосвідомості без оформлення у концепцію.

Останнім часом набули певного поширення також спроби узалежнити типологію праворозуміння від типології стадій розвитку наукового раціоналізму. За таким підходом цей раціоналізм проходить три стадії розвитку: класичну, некласичну та постнекласичну. У сучасній теоретичній юриспруденції ця тричленна типологія зазнає певної модифікації стосовно типів праворозуміння. Так, І.Л. Честнов виокремлює класичний та посткласичний типи праворозуміння, відносячи до ключових характеристик останнього застосування при поясненні й обгрунутванні правової реальності трьох «поворотів»: лінгвістичного, антропологічного та прагматичного. Тому право в його розумінні - це текст, що $є$ результатом людської діяльності та від- 
творюється діями й ментальними уявленнями людей. Тобто право - це не статична структура, а триваючий «процес відтворення правової реальності» [19].

Варто звернути увагу на глибоке дослідження А. Скоробагатова, який у спробах віднайти критерії класифрікації для типології праворозуміння, визначення яких здебільшого уникають, виокремлює такі [20]: домінуюча картина світу та загальнонаукова парадигма доби; філософська доктирна та юридичний світогляд суб'єкта праворозуміння; методи аналізу феномену права. За цими параметрами він бачить класичне праворозуміння (право можна пізнати і пояснити за допомогою однієї «правильної» теорії, яку слід віднайти) та посткласичне праворозуміння (право - багатовимірне явище; за допомогою тільки теорії права пізнати його неможливо, сутність права допомагають розкрити звернення до фрілософії права, соціології права та інших юридичних і гуманітарних наук).

У рамках класичного праворозуміння, відтак, можна виділити два домінуючих типи праворозуміння - юснатуралізм і позитивізм. У посткласичному праворозумінні виявляємо два провідні підходи - інтегративний та постмодерністський. До першого належать теорії, що характеризуються прагненням поєднати в рамках єдиної правової теорії окремі прояви буття права - ціннісний (юснатуралізм), нормативний (етатизм), соціальний (соціологія права). Серед теорій інтегративного праворозуміння виокремлюються: інтегративна юриспруденція (Дж. Голл [21], Г. Дж. Берман [22]), реалістичні теорії права (К. Ллевеллін [23], Дж. Френк [24], К. Олівекрона [25; 26]), школа критичних правових досліджень (Р. Ангер, М. Келман) [27], економічна теорія права (Р. Познер [28]).

Постмодерністсьий напрям праворозуміння А. Скоробагатов пропонує розглядати в єдності таких течій: феноменології права, герменевтики права, екзистенціалізму права, антропології права, синергетики права та діалогічної теорії права [20].

О. Тимошина розрізняє два типи праворозуміння - класичний та посткласичний (посилаємося на ії̈ думку, але не забуваємо про заангажовану і не обгрунтовану критику Тимошиною О. творчості видатного вченого Л. Петражицького, що уже було предметом нашого дослідження [29]). На її думку, класична і посткласична типологія $є$ своєрідним стилем фрілософсько-правового мислення, типологічні особливості яких визначаються типом наукової раціональності. В основі класичної і посткласичної типології лежить уявлення про те, що наукове знання $\epsilon$ явищем, яке історично розвивається та фрормується в межах певного соціокультурного контексту [30]. О.В. Тимошина, розрізняючи класичні та некласичні типи праворозуміння, віднесла до ключових ознаки перших, з яких наведемо такі, що не викликають заперечень: 1) об'єктивістька інтерпретація буття права; 2) кореспондентна теорія істини"; 3) вивчення об'єкта в «чистому» вигляді, без урахування соціокультурних детермінант; 4) прескриптивний (описовий) характер теорії, яка $€$ плацдармом для здійснення теоретичних схем. Натомість для некласичних типів праворозуміння називаються такі ознаки: 1) процесуальність інтерпретаційних практик суб'єктів; 2) конституювання предмета методом дослідження; 3) когерентна теорія істини; 4) незавершеність теоретико-правового знання; 5) соціокультурна детермінація правової рефлексії; 6) розгляд теорії права не як абстрактного знання, а як теоретико-методологічного набору засобів, методів техно-юридичних прийомів вирішення конкретних питань у правотворчій та правозастосовній діяльності, усій політико-правовій практиці, а також науковій, науково-дослідній та освітній роботі.

Типовими класичними типами праворозуміння виявилися юснатуралізм і юспозитивізм, які являють собою раціоналістичний та емпіричний варіанти фрілософсько-правового натуралізму. Натомість для некласичних типів правопрозуміння властиві ускладнення картини правової реальності, а тому некласичні інтерпретації права як апріорної ідеї права, «веління суверена» чи «правопорядку» сприймаються як беззмістовні [31].

Відзначимо аргументовану позицію С. Максимова, який вважає, що типологія праворозуміння вибудовується залежно від того, що пропонується у якості основи правової реальності, тобто простору, де локалізуються правові сенси. Згідно з таким підходом виокремлено чотири типи праворозуміння: 1) правовий позитивізм - на зовнішньому боці правової реальності, сукупності норм, забезпечених примусовою силою держави; 2) правовий об'єктивізм - на соціальній обумовленості права, його вкоріненості в житті; 3) правовий суб'єктивізм, або класичні концепції природного права, - на ідеально-моральному боці права, який розкривається у свідомості суб'єкта ідеї права; 4) правова інтерсуб'єктивність, або некласичні концепції природного права, - на тому смисловому боці права, який проявляється у процесі взаємодії суб'єктів [32]. Три перші (правовий позитивізм, правовий об'єктивізм, правовий суб'єктивізм) виражають класичні типи праворозуміння, засновані на розподілі сутності та існування (як теорія природного права та юспозитивізм), суб'єкта та об'єкта (як суб'єктивізм та об'єктивізм), вони виходять із зовнішньої позиції дослідника як спостерігача. Вчений протиставляє їм некласич-

\footnotetext{
1 Концепція, за якою твердження повинні відповідати навколишній дійсності.

2 Концепція, що зводить проблему істинності до критерію когерентності (coherence) - самоузгодженості, несуперечливості: напр., теза є істинною, якщо вона є елементом логічно взаємоповязаної та когерентної системи.
} 
ний підхід до праворозуміння, що ґрунтується на подоланні однобічності інших підходів, - позиція інтерсуб'єктивності, яка виходить із положення дослідника як учасника правових подій, що реалізується, передусім, у френоменолого-герменевтичній та комунікативно-дискурсивній формах [33].

Як видно, досі в теоретичній юриспруденції не існує загальноприйнятої класифрікації типів праворозуміння, при тому що вченими пропонуються доволі різні критеріальні основи для таких класифікацій. Такі версії та інтерпретації мають сенс у контексті розуміння та сприйняття як актуального плюралістичного (за сутністю) постмодерністського світоустрою та його складової частини - сфери правової регуляції [34]. Разом із тим спостерігаємо соціальну чи навіть соціолого-правову зумовленість сучасних типологій праворозуміння. Вчені не можуть обійти той фракт, що право $є$ соціальним явищем, результатом діяльності суспільства і людини, тобто результатом комунікації, легалізації та легітимації інтересів та цілепокладання, боротьби ідей і підходів, компромісів і антагонізмів. Більше того, межі та евристичні можливості кожної концепції чи тлумачення, які є частковими відповідями на глобальні питання, за нинішніх умов самі $€$ украй рухливими, динамічними, а тому й інваріантними.

\section{Список використаних джерел:}

1. Костицький В.В. Проблеми ренесансу в сучасній теорії права. Малий і середній бізнес. 2009. № 1-2. С. 3-10.

2. Рабінович П. Деякі сучасні концепції права в Росії та Україні (у світлі потребового праворозуміння. Філософія права і загальна теорія права. 2013. № 1. С. 154.

3. Малько А.В. Теория государства и права в вопросах и ответах. Москва : Юристъ, 2015. С. 34.

4. Байтин М.И. Сущность права (Современное нормативное правопо-нимание на грани двух веков) Москва, 2005. C. 23.

5. Леушин В.И. Понятие, сущность и социальная ценность права. Теория государства и права / Под ред. В.М. Корельского, В.Д. Перевалова. Москва, 1998. С. 217.

6. Костицький В.В. Право як цілісність. Право України. 2002. № 2. С. 8-9.

7. Попов В.И. Методологические основания многоаспектного подхода к пониманию права и его значение для юридической практики. LEX RUSSICA. 2019. № 3(178)- С. 10.

8. Гойман-Калинский И.В., Иванец Г.Н., Червонюк В.И. Элементарные начала общей теории права : учебное пособие / под ред. В.И. Червонюка. Москва, 2003. С. 63.

9. Нерсесянц В.С. Философия права Гегеля. Москва, 1998. С. 132.

10. Лапаева В.В. Различные типы правопонимания: анализ научно-практического потенциала. Законодательство и экономика. 2006. № 4. С. 103-115.

11. Нерсесянц В.С. Философия права: либертарно-юридическая концепция. Вопросы философии. 2002. № 3. C. 10 .

12. Скакун О.Ф. Теорія держави і права : підручник. 2-е вид. / Пер. з рос. Харків : Консум, 2005. С. 216.

13. Козюбра М. Праворозуміння: поняття, типи та рівні. Право України. 2010. № 4. С. 15.

14. Мартышин О.В. Совместимы ли основные типы понимания права? Государство и право. 2003. № 6. С. 13-15.

15. Бернацкий Г.Г. Евгений Николаевич Трубецкой: естественное право и религия. Санкт-Петербург, 1999. C. $48-50$.

16. Костицький В.В. Право як цілісність: теолого-соціологічний підхід. Соиіологія права. 2012. № 1(3). С. 3-9.

17. Философия права : учеб. пособие / П.П. Баранов, В.Ю. Шпак, Е.Е. Несмеянов, А.И. Лукьянов. Ростов н/Д, 2002. C. 12

18. Поляков А.В. Общая теория права : курс лекций. Санкт-Петербург, 2001. С. 36-37.

19. Честнов И.Л. Постклассическая теория права. Монография. С. 12.

20. Скорбогатов А.В. Типология правопонимания: сравнительно-правовой анализ. Актуальные проблемы экономики и права. 2008. № 4. С. 147-150.

21. Холл Дж. Интегративная юриспруденция // Антология мировой правовой мысли. В 5 т. Т. 3. Москва, 1999. C. $740-742$.

22. Берман Г. Дж. Западная традиция права : эпоха формирования. Москва : Изд-во МГУ: Издательская группа ИНФРА- $M$-НОРМА, 1998. 624 с.

23. Ллевеллин К.Н. Немного реализма о реализме. Антология мировой правовой мыссли. В 5 т. Т. 3. Москва, 1999. C. $690-691$.

24. Фрэнк Дж. Право и современное сознание. Антология мировой правовой мысли. В 5 т. Т. 3. Москва, 1999. C. $684-685$.

25. Оливекрона К. Право как факт / К. Оливекрона ; Пер. Е. Ю. Таранченко ; Науч. ред. пер. А.В. Поляков, М.В. Антонов. Российский ежегодник теории права, 2008. № 1. Санкт-Петербург : ООО «Университетский издательский консорциум «Юридическая книга», 2009. С. 669-752.

26. Антонов М.В. Скандинавская школа правового реализма. Российский ежегодник теории права. № 1. 2008 / Под ред. А.В. Полякова. Санкт-Петербург : ООО «Университетский издательский консорциум «Юридическая книга», 2009. С. 645-668. 
27. Сметанников Д.С. Школа критических правовых исследований : дисс. ... канд. юрид. наук : 12.00 .01$. Санкт-Петербург, 2000149 с.

28. Познер Р. Экономический анализ права / Р. Познер ; пер. с англ. А. А. Фофонова под редакцией В.Л. Тамбовцева. Санкт-Петербург : Экономическая школа, 2004. Т. 1-2. 974 с.

29. Wasyl W. Kostytsky., Kwestia oceny dziedzictwa prawnego Leona Petrazyckiego w nowoczesnej doktrynie prawnej Ukrainy. Leon Petrazycki i jego dzielo. Warszawa. Stydia Iridica. 2018. P. 163-184.

30. Тимошина Е.В. Классика, постклассика... неоклассика: к обоснованию контрпостмодернистской программы в теории права. Правоведение. 2014. № 4. С. 9.

31. Тимошина Е.В. Теория и социология права Л.И. Петражицкого в контексте классического и постклассического правопонимания : автореф. дис. ... Д. ю. н. : 12.00.01; Институт государства и права РАН. Москва, 2013. С. 22.

32. Максимов С.И. Правовая реальность : опыт философского осмысления. Харьков : Право, 2002. С. $138-142$.

33. Максимов С.И. Классическая и неклассическая модели осмысления правовой реальности в контексте коммуникативной парадигмы права. Известия вузов. Правоведение. 2014. № 6. С. 49.

34. Козлихин И.Ю. О нетрадиционных подходах к праву. Правоведение. 2006. № 1. С. 31-40.

35. Пищулин А.В. Юридический позитивизм в современном правопонимании : автореф. дисс. ... канд. юрид. наук : 12.00.01 ; Моск. гос. ун-т им. М.В. Ломоносова. Москва, 2010. С. 12.

36. Лук'янова Г.Ю. Компліментарно-цілісна концепція праворозуміння (аспекти загальної теорії) : авто-реф. дис. на здобуття наук. ступеня канд. юрид. Наук : 12.00.01. Львів, 2013. 21 с.

37. Проблемы теории государства и права : учебник / под ред. В.М. Сырых. Москва, 2008. С. 41. 


\section{МОДЕЛЮВАННЯ КІЛЬКІСНИХ ПОКАЗНИКІВ ЗЛОЧИННОСТІ ЗА ДОПОМОГОЮ АЛГОРИТМІВ КЛАСТЕРНОГО ТА КАНОНІЧНОГО АНАЛІЗУ}

\section{MODELING OF QUANTITATIVE CRIME INDICATORS USING CLUSTER AND CANONICAL ANALYSIS ALGORITHMS}

У статті автор аналізує показники судової статистики і деякі традиційні та експериментальні економічні, соціально-демографічні фактори за допомогою алгоритмів кластерного та канонічного аналізу. Кластерний аналіз дозволяє зрозуміти соціальну природу відмінностей рівня та структури злочинності в регіонах України. Натомість канонічний аналіз дозволяє віднайти приховані кореляційні залежності та отримати нові знання про фактори, які супроводжують криміногенну картину в регіоні.

У результаті проведеного дослідження за допомогою кластерного аналізу судової статистики дістала наукове підтвердження гіпотеза, що на структуру злочинності в Україні відчутний вплив здійснює панівний спосіб виробництва в регіоні.

Для з'ясування міри впливу окремих соціальних факторів за допомогою канонічного аналізу було виявлено декілька 3 них, що корелюють з рівнем та впливають на структуру злочинності регіону. До таких факторів варто віднести: кількість зареєстрованих та розірваних шлюбів, дохід у розрахунку на одну особу, викиди забруднюючих речовин, кількість інтернет користувачів у регіоні.

У результаті висунуті обгрунтовані припущення: 1) значна кількість засуджених за злочини середньої тяжкості належить саме до міського населення, а велика кількість засуджених за злочини невеликої тяжкості належить до представників сільської місцевості; 2) злочини одружених осіб, частіше ніж інших, належать саме до категорії злочинів середньої тяжкості, але такий вид покарання, як громадські роботи, до них застосовується рідше; 3) збільшення розлучень має загальний криміногенний вплив; 4) злочини проти власності є найбільш чутливими до економіко-фінансових факторів, а фінансові кризи призводять до зростання дрібних правопорушень та злочинів невеликої тяжкості; 5) існує вплив забруднення середовища на кількість злочинів середньої тяжкості, тяжких і особливо-тяжких, а також є зв'язок між цим фактором та систематичним заняттям злочинною діяльністю; 6) інтернет-користування в сучасному контексті злочинних проявів відіграє швидше запобіжну роль, ніж кримінально провокуючу.

Ключові слова: судова статистика, предиктори злочинності, стандартизаиія, кластерний аналіз, канонічний аналіз, дисперсійний аналіз.

In the article the author analyzes the indicators of judicial statistics and some traditional and experimental economic, socio-demographic factors using cluster and canonical analysis algorithms. Cluster analysis allows us to understand the social nature of differences in the level and structure of crime in the regions of Ukraine. Instead, canonical analysis allows to find hidden correlations and gain new knowledge about the factors that accompany the criminogenic picture in the region.

As a result of the study, with the help of cluster analysis of judicial statistics, the hypothesis that the structure of crime in Ukraine is significantly influenced by the dominant mode of production in the region was scientifically confirmed.

To determine the extent of the impact of individual social factors through canonical analysis, several of them were identified that correlate with the level and influence the crime structure of the region. Such factors include: the number of registered and dissolved marriages, income per capita, emissions of pollutants, the number of Internet users in the region.

As a result, reasonable assumptions have been made: 1) a significant number of convicts for moderate crimes belong to the urban population, and a large number of convicts for minor crimes belong to rural areas; 2) crimes of married persons, more often than others, belong to the category of crimes of medium gravity, but this type of punishment as community service is applied to them less often; 3) the increase in divorce has a general criminogenic effect; 4) crimes against property are the most sensitive to economic and financial factors. And financial crises lead to an increase in petty offenses and minor crimes; 5) there is an impact of environmental pollution on the number of crimes of medium gravity, serious and especially serious, and there is a connection between this factor and the systematic pursuit of criminal activity; 6) Internet use in the modern context of criminal acts plays a preventive role rather than a criminal one.

Key words: forensic statistics, crime predictors, standardization, cluster analysis, canonical analysis, analysis of variance. 
Вступ. Діяльність судів у всьому світі $€$ важливим складником боротьби зі злочинністю. Відображенням такої боротьби є судова статистика, що збирається Державною судовою адміністрацією України. Різноманітні статистичні дані, які характеризують розгляд кримінальних справ в Україні, стосуються самого злочину, особи підсудного та результатів розгляду справи. Зокрема, у разі визнання особи винною у вчиненні злочину є доступними статистичні дані про призначене покарання в розрізі регіонів України.

Слід сказати, що різні регіони України характеризуються різними соціально-економічними показниками, демографрічними характеристиками, місцевими традиціями, а також і різним співвідношенням окремих видів злочинів. Кримінологічна характеристика окремого регіону України має на меті фрормування удосконаленої аналітичної концепції судової реформи, а також у більш широкому вимірі концепції реформи правоохоронних органів та адміністративної реформи в Україні.

Аналіз наявної судової статистики за допомогою алгоритмів кластерного та канонічного аналізу дозволяє віднайти приховані кореляційні залежності та отримати нові знання про фрактори, які супроводжують криміногенну картину в регіоні, певним чином впливають на структуру злочинності та ефективність судових рішень у боротьбі зі злочинністю.

$€$ багато наукових досліджень, присвячених дослідженню питання ефективності покарань в Україні. Зокрема, О.О. Шкута, досліджуючи теоретико-прикладні засади функціонування кримінально-виконавчої системи України, обґрунтовує необхідність урахування комплексного впливу на рецидивну злочинність низки соціально-економічних умов в суспільстві, якість роботи інститутів соціальної реабілітації осіб, звільнених з місць ізоляції від суспільства, а також інші зовнішні фрактори, які однозначно пов'язані з результатами виправного впливу на засудженого, а також володіють значним автономним потенціалом впливу на зазначених осіб [1, с. 367].

Аналіз міжнародних наукових публікацій дає можливість оцінити ефрективність застосування різноманітних методів статистичної обробки даних для вирішення кримінологічних проблем. Так, Razana Alweea, Siti Mariyam Shamsuddinb, Roselina Sallehuddin (Малайзія) у дослідженні, присвяченому моделюванню центрів впливу на злочинність з боку економічних показників, створюють часові ряди показників злочинності. Також додано кілька фракторів, які здійснюють вплив на злочинність, зокрема економічні, соціальні та демографічні показники. Методологічну основу дослідження складає «сірий реляційний аналіз» (Grey relational analysis (GRA)). Його використано для дослідження нелінійної множинної одномірної моделі впливу соціальноекономічних та деяких інших показників на зло- чинність з метою побудови прогнозів злочинної активності. Автори запевняють, що запропонований метод здатний розпізнати нелінійні відносини між економічними показниками та рівнем злочинності, ранжувати економічні індикатори та обрати найбільш важливі щодо злочинності. Таким чином, описувана модель $€$ досить корисною для реалізації моделювання рівня насильницьких злочинів та їх прогнозування. Доведено зв'язок між безробіттям, втратою доходів, що $€$ причиною депресії та відчаю і може сприяти вчиненню насильницьких злочинів, зокрема вбивств. Водночас збільшення індексів споживчих цін, зростання інфрляції впливає на зменшення кількості злочинів проти власності [2].

У дослідженні Arye Rattner представлена спроба використати макродинамічні соціальні індикатори в аналізі часових рядів трьох категорій злочинів: вбивства, крадіжки та грабежі в Ізраїлі. Аналізом підтверджується взаємозв'язок між вбивствами та безробіттям, між щільністю населення та злочинами проти власності. Ці ж моделі здатні до прогнозування показників злочинності [3].

Juan Esteban Carranza Romero із співавторами провели схоже дослідження та проаналізували вплив економічної діяльності на рівень вбивств у регіонах Колумбії, а також їх співвідношення з іншими видами злочинності. 3 цією метою створена модель даних за допомогою інструментальних змінних, яка показує, що збільшення економічної активності зменшує кількість вбивств. Навіть більше, кількість вбивств негативно корелює зі злочинами проти власності. Ці дані також свідчать про те, що злочинці підтримують свою незаконну діяльність протягом усього економічного циклу, змінюючи різні види злочинів [4].

Попри значне поширення кримінологічного моделювання та прогнозування злочинності за допомогою методів статистичного аналізу в іншомовних наукових дослідженнях, вітчизняна українська кримінологія наразі робить лише перші кроки в цьому напряму. Зокрема, демонстрація окремих методів та прийомів кримінологічного моделювання і прогнозування злочинності на українських даних міститься в спеціальному монографічному дослідженні, оприлюдненому в 2020 році [5].

У цій статті пропонується демонстрація використання кластерного аналізу на даних судової статистики з метою виокремлення регіонів з різним рівнем та структурою злочинності, а також канонічного аналізу після додавання деяких економічних та соціально-демографічних фракторів з метою виявлення міри залежності цих предикторів та показників судової статистики. Базовим для аналізу є 2019 рік.

Метою статті $є$ демонстрація використання методів кластерного аналізу та канонічного аналізу для моделювання кількісних показників 
злочинності та отримання нової кримінологічно значущої інформації.

Завданнями дослідження $є:$ 1) кластерний аналіз показників судової статистики в розрізі регіонів України; 2) канонічний аналіз показників судової статистики та окремих економічних і соціально-демографічних показників та виявлення кореляційних залежностей.

Для досягнення мети ми спочатку застосуємо методи модулю Data Mining на базі STATISTICA (StatSoft). Зазначений модуль дозволяє досліджувати і виявляти за допомогою спеціальних алгоритмів у необроблених даних приховані знання, які раніше не були відомими, є нетривіальними, практично корисними, доступними для інтерпретації людиною. У нашому дослідженні ми застосуємо алгоритми кластеризації.

Йдеться перш за все про розбиття досліджуваних даних, що подані в розрізі регіонів України, на кластери, тобто групи спостережень, ґрунтуючись не на одному, а на цілому наборі предикторів, тому виділені такі етапи дослідження: 1) кластерний аналіз відносних кількісних показників, що висвітлюють результати роботи судів у регіонах України в 2019 році; 2) графічне представлення та візуалізація окремих етапів проведеного аналізу 3 метою демонстрації методу; 3) окреслення шляхів практичного застосування отриманих результатів кластерного аналізу з метою удосконалення діяльності судів у кримінальних провадженнях.

У подальшому до початкових предикторів необхідно додати кілька показників економічного та соціально-демографрічного характеру і за допомогою модулю канонічної кореляції в STATISTICA провести аналіз залежностей між цими двома списками змінних. Зазначений модуль дозволяє дослідити залежність між двома множинами змінних, тому отримані результати можуть бути інтерпретовані з позиції кримінологічної значущості того чи іншого показника.

Початкова структура даних представляє собою 10 показників, що представляють собою підсумкові дані Державної судової адміністрації України за 2019 рік у розрізі регіонів, переведені у відносні показники. Рядки сформованої таблиці представлені регіонами України в кількості 25 спостережень. Дані з Донецької та Луганської областей представляють лише територію, підконтрольну Україні. Дані з Автономної Республіки Крим та м. Симферопіль відсутні через тимчасову окупацію півострова [6; 7].

Серед змінних аналізу знаходяться такі параметри. Це питома вага від усіх засуджених у регіоні: 1) засуджених до позбавлення волі; 2) засуджених за тяжкі та особливо тяжкі злочини; 3) засуджених за злочини середньої тяжкості; 4) засуджених за злочини невеликої тяжкості; 5) осіб, на яких накладено штраф;; 6) осіб, яким призначено громадські роботи; 7) осіб, до яких застосовано арешт; 8) осіб, до яких застосовано обмеження волі; 9) осіб, яких звільнено від покарання та його відбування з випробуванням; 10) осіб, яким призначено покарання за сукупністю злочинів та сукупністю вироків.

Зазначені показники наведено в таблиці 1.

Таблиця 1

Відносні показники покарань, що були призначені судами України у 2019 році, за регіонами

\begin{tabular}{|c|c|c|c|c|c|c|c|}
\hline № & Регіони України & $\begin{array}{c}\text { Питома } \\
\text { вага засу- } \\
\text { джених до } \\
\text { позбавлен- } \\
\text { ня волі, \% }\end{array}$ & $\begin{array}{c}\text { Питома вага } \\
\text { засуджених за } \\
\text { тяжкі та осо- } \\
\text { бливо тяжкі } \\
\text { злочини, \% }\end{array}$ & \begin{tabular}{|c|} 
Питома вага \\
засуджених \\
за злочини \\
середньої \\
тяжкості, \%
\end{tabular} & $\begin{array}{c}\text { Питома вага } \\
\text { засуджена } \\
\text { за злочини } \\
\text { невеликої } \\
\text { тяжкості, \% }\end{array}$ & $\begin{array}{c}\text { Питома вага } \\
\text { осіб, яким } \\
\text { призначено } \\
\text { штраф, \% }\end{array}$ & $\begin{array}{c}\text { Питома вага } \\
\text { осіб, яким } \\
\text { призначено } \\
\text { громадські } \\
\text { роботи, \% }\end{array}$ \\
\hline A & 5 & 1 & 2 & 3 & 4 & 5 & 6 \\
\hline 1 & АР Крим & - & - & - & - & - & - \\
\hline 2 & Вінницька & 23,0 & 34,7 & 51,5 & 13,8 & 27,7 & 6,5 \\
\hline 3 & Волинська & 14,6 & 32,5 & 50,0 & 17,5 & 36,9 & 7,6 \\
\hline 4 & Дніпропетровська & 29,0 & 35,2 & 53,2 & 11,6 & 19,3 & 4,4 \\
\hline 5 & Донецька & 19,3 & 32,9 & 56,2 & 10,9 & 31,6 & 8,4 \\
\hline 6 & Житомирська & 14,0 & 28,6 & 53,6 & 17,8 & 31,0 & 9,3 \\
\hline 7 & Закарпатська & 14,0 & 38,0 & 45,5 & 16,5 & 27,3 & 4,5 \\
\hline 8 & Запорізька & 16,6 & 28,5 & 59,1 & 12,5 & 24,9 & 7,0 \\
\hline 9 & Івано-Франківська & 15,2 & 32,4 & 48,3 & 19,3 & 41,5 & 8,7 \\
\hline 10 & Київська & 18,2 & 31,4 & 57,1 & 11,5 & 34,4 & 3,9 \\
\hline 11 & Кіровоградська & 17,5 & 35,4 & 50,7 & 13,9 & 27,1 & 4,5 \\
\hline 12 & Луганська & 14,8 & 36,8 & 47,0 & 16,3 & 22,5 & 6,4 \\
\hline 13 & Львівська & 17,1 & 30,1 & 50,0 & 20,0 & 35,9 & 4,0 \\
\hline 14 & Миколаївська & 14,6 & 34,4 & 49,9 & 15,7 & 28,3 & 7,2 \\
\hline 15 & Одеська & 17,9 & 40,2 & 46,9 & 12,8 & 27,9 & 2,7 \\
\hline 16 & Полтавська & 17,9 & 27,0 & 60,7 & 12,3 & 31,7 & 6,7 \\
\hline 17 & Рівненська & 11,9 & 35,2 & 51,2 & 13,5 & 32,1 & 7,1 \\
\hline
\end{tabular}


Продовження таблиці 1

\begin{tabular}{|c|c|c|c|c|c|c|c|}
\hline A & Б & $\mathbf{1}$ & $\mathbf{2}$ & $\mathbf{3}$ & $\mathbf{4}$ & $\mathbf{5}$ & $\mathbf{6}$ \\
\hline 18 & Сумська & 16,4 & 31,6 & 55,1 & 13,3 & 40,0 & 9,1 \\
\hline 19 & Тернопільська & 11,2 & 28,8 & 53,0 & 18,2 & 43,1 & 6,0 \\
\hline 20 & Харківська & 24,4 & 34,5 & 52,6 & 12,9 & 21,2 & 4,7 \\
\hline 21 & Херсонська & 21,9 & 29,3 & 52,8 & 17,9 & 29,7 & 8,2 \\
\hline 22 & Хмельницька & 14,9 & 28,6 & 56,3 & 15,1 & 38,5 & 7,2 \\
\hline 23 & Черкаська & 15,2 & 32,3 & 48,5 & 19,2 & 34,1 & 5,2 \\
\hline 24 & Чернівецька & 18,2 & 24,6 & 53,1 & 22,4 & 40,8 & 4,8 \\
\hline 25 & Чернігівська & 16,2 & 35,6 & 47,6 & 16,8 & 32,6 & 10,0 \\
\hline 26 & м. Київ & 16,7 & 19,5 & 70,3 & 10,2 & 44,5 & 1,9 \\
\hline 27 & м. Севастополь & - & - & - & - & - & - \\
\hline 28 & Всього по Україні & 18,8 & 32,0 & 53,7 & 14,3 & 30,4 & 6,0 \\
\hline
\end{tabular}

Закінчення таблиці 1

\begin{tabular}{|c|c|c|c|c|c|}
\hline № & Регіони України & $\begin{array}{c}\text { Питома вага } \\
\text { осіб, до яких } \\
\text { застосовано } \\
\text { арешт, \% }\end{array}$ & \begin{tabular}{|c|} 
Питома вага \\
осіб, до яких \\
застосовано обме- \\
ження волі, \%
\end{tabular} & $\begin{array}{c}\text { Питома вага осіб, } \\
\text { яких звільнено від } \\
\text { покарання та його } \\
\text { відбув. з випробу- } \\
\text { ванням, \% }\end{array}$ & $\begin{array}{c}\text { Питома вага осіб, } \\
\text { яким призначе-- } \\
\text { но покарання за } \\
\text { сукупністю, \% }\end{array}$ \\
\hline $\mathbf{A}$ & 5 & 7 & 8 & 9 & 10 \\
\hline 1 & АР Крим & - & - & - & - \\
\hline 2 & Вінницька & 4,2 & 1,2 & 34,4 & 27,7 \\
\hline 3 & Волинська & 3,2 & 0,9 & 35,3 & 24,9 \\
\hline 4 & Дніпропетровська & 2,0 & 1,3 & 42,5 & 35,8 \\
\hline 5 & Донецька & 5,7 & 1,0 & 31,8 & 22,8 \\
\hline 6 & Житомирська & 3,4 & 1,5 & 36,5 & 23,2 \\
\hline 7 & Закарпатська & 1,1 & 2,0 & 47,2 & 21,0 \\
\hline 8 & Запорізька & 2,9 & 1,0 & 45,8 & 28,9 \\
\hline 9 & Івано-Франківська & 6,6 & 1,3 & 23,5 & 22,4 \\
\hline 10 & Київська & 2,3 & 1,3 & 39,0 & 19,6 \\
\hline 11 & Кіровоградська & 1,5 & 0,6 & 47,8 & 29,4 \\
\hline 12 & Луганська & 1,8 & 1,1 & 48,5 & 15,8 \\
\hline 13 & Львівська & 3,2 & 1,0 & 35,9 & 24,7 \\
\hline 14 & Миколаївська & 2,3 & 0,7 & 44,8 & 24,3 \\
\hline 15 & Одеська & 3,1 & 0,6 & 46,0 & 19,5 \\
\hline 16 & Полтавська & 2,7 & 1,0 & 39,2 & 24,9 \\
\hline 17 & Рівненська & 1,3 & 1,3 & 44,2 & 23,9 \\
\hline 18 & Сумська & 8,5 & 3,2 & 20,6 & 27,2 \\
\hline 19 & Тернопільська & 3,0 & 0,5 & 34,2 & 21,3 \\
\hline 20 & Харківська & 3,0 & 1,4 & 43,3 & 28,5 \\
\hline 21 & Херсонська & 6,0 & 1,5 & 31,7 & 24,9 \\
\hline 22 & Хмельницька & 4,4 & 1,0 & 31,8 & 22,7 \\
\hline 23 & Черкаська & 2,7 & 0,4 & 40,7 & 20,4 \\
\hline 24 & Чернівецька & 6,8 & 1,5 & 26,0 & 19,0 \\
\hline 25 & Чернігівська & 8,8 & 0,8 & 29,9 & 25,1 \\
\hline 26 & м. Київ & 2,9 & 1,0 & 30,9 & 20,3 \\
\hline 27 & м. Севастополь & - & - & - & - \\
\hline 28 & Всього по Україні & 3,6 & 1,2 & 38,0 & 25,1 \\
\hline
\end{tabular}

Кластеризація належить до класу unsupervised learning (непідконтрольне навчання). При цьому ми не володіємо інфрормацією, до якого класу належать ті чи інші спостереження. Задача кластеризації вирішується на початкових етапах дослідження. ІІї розв'язок допомагає краще зрозуміти самі дані та їх природу. Кластерний аналіз дозволяє проводити розбиття об'єктів на кластери не по одному, а по цілому набору ознак, автоматично визначаючи оптимальну кількість кластерів.

Для реалізації модулю кластеризації необхідно, щоб змінні мали однакову варіабельність (діапазон). Для цього використаємо процедуру стандартизації в Data Mining. Після стандартизації отримуємо дещо видозмінену таблицю 
і саме для цих даних використаємо наявний у модулі алгоритм кластеризації К-середніх. Цей алгоритм розбиває підмножину елементів векторного простору на завчасно відоме число кластерів к. Дія алгоритму полягає в тому, що він прагне мінімізувати середньоквадратичне відхилення на крапках кожного кластеру. Основна ідея полягає в тому, що на кожній ітерації перераховується центр мас для кожного кластеру, отриманого на попередньому кроці, потім вектори розбиваються на кластери знову відповідно до того, який з нових центрів опинився ближче по обраній метриці. Алгоритм завершується, коли на певній ітерації не відбувається зміни центрів кластерів.

Результати кластеризації представлені в таблиці 2.

Середні у кожному кластері, отримані в результаті аналізу, внесені програмою до таблиці. Ії̈ фррагмент наводимо у вигляді таблиці 3.

У рядках таблиці 3 розташовані номери кластерів. Стовпців у отриманій в STATISTICA таблиці - 25, за числом змінних, що беруть участь в аналізі. Наведений в Таблиці 3 фрагмент містить лише 4 змінних проведеного аналізу. Два останні стовпчики таблиці вказують на число спостережень та їх відсоток у кожному кластері.

Були отримані такі кластери:

Кластер 1: Волинська, Донецька, Житомирська, Івано-Франківська, Львівська, Сумська, Тернопільська, Херсонська, Хмельницька, Черкаська, Чернівецька, Чернігівська області. Всього 12 регіонів, частка в загальному масиві спостережень $48 \%$.

Кластер 2: Київська, Полтавська області, м. Київ. Всього 3 регіони, частка в загальному масиві спостережень $12 \%$.

Кластер 3: Вінницька, Дніпропетровська, Закарпатська, Запорізька, Кіровоградська, Луганська, Миколаївська, Одеська, Ровенська, Харківська. Всього 10 регіонів, частка в загальному масиві спостережень 40\%.
Таблиця 2

Підсумкова кластеризація за алгоритмом К-середніх (Стандартизовані дані)

\begin{tabular}{|l|l|}
\hline Algorithm & k-Means \\
Distance method & Euclidean distances \\
MDitial centers & Maximize initial distance \\
Cross-validation & Yes \\
Testing sample & 5 folds \\
Training cases & 0 \\
Training error & 25 \\
Number of clusters & 1,076648 \\
\hline
\end{tabular}

Відстані між кластерами (Cluster distance) відображені в таблиці 4.

3 метою демонстрації ролі окремих факторів під час кластеризації наведемо графрік.

3 метою визначення факторів, що найбільше впливають на приналежність об'єкта кластеру, проведемо дисперсійний аналіз.

Виходячи з дисперсійного аналізу, змінні: «Засуджені за тяжкі та особливо тяжкі злочини», «Засуджені за злочини середньої тяжкості», «Засуджені за злочини невеликої тяжкості», «Накладено штраф», «Призначено громадські роботи», «Застосовано арешт», «Звільнено від покарання з випробуванням» істотно вплинули на кластеризацію, тобто $є$ значущими $(p<0,05)$, у той же час роль фракторів: «Засуджені до позбавлення волі», «Застосовано обмеження волі», «Призначено покарання за сукупністю злочинів та вироків» під час кластеризації $€$ меншою $(p>0,05)$. Отримані таким чином відомості цілком узгоджуються з наведеним вище графріком (рисунок 1).

Таким чином, відбувся доволі чіткий географрічний поділ регіонів України на кластери, де до першого кластеру програма віднесла пере-

Середні для кластеризації (Стандартизовані)

\begin{tabular}{|c|c|c|c|c|c|c|}
\hline Кластери & $\begin{array}{c}\text { Засуджено до } \\
\text { позбавлення } \\
\text { волі }\end{array}$ & $\begin{array}{c}\text { Засуджено за } \\
\text { тяжкі та осо- } \\
\text { бливо тяжкі } \\
\text { злочини }\end{array}$ & $\begin{array}{c}\text { 3вільнено } \\
\text { від покарання 3 } \\
\text { випобуванням }\end{array}$ & $\begin{array}{c}\text { Призначено } \\
\text { покарання за } \\
\text { сукупністю }\end{array}$ & $\begin{array}{c}\text { Номери } \\
\text { спостережень }\end{array}$ & Відсоток (\%) \\
\hline 1 & $-0,264752$ & $-0,29274$ & $-0,735606$ & $-0,169676$ & 12 & 48,00000 \\
\hline 2 & 0,094277 & $-1,32551$ & $-0,113922$ & $-0,555303$ & 3 & 12,00000 \\
\hline 3 & 0,289419 & 0,74894 & 0,916904 & 0,370202 & 10 & 40,00000 \\
\hline
\end{tabular}

Стандартизовані дистанції між центральними точками кластерів

Таблиця 4

\begin{tabular}{|c|c|c|c|}
\hline & Кластер 1 & Кластер 2 & Кластер 3 \\
\hline Кластер 1 & 0,000000 & 1,338826 & 1,320087 \\
\hline Кластер 2 & 1,338826 & 0,000000 & 0,000000 \\
\hline Кластер 3 & 1,320087 & 1,350823 & \\
\hline
\end{tabular}


Дисперсійний аналіз безперервних змінних

\begin{tabular}{|c|c|c|c|c|c|c|}
\hline \multirow{2}{*}{} & \multicolumn{4}{|c|}{ Дисперсійний аналіз безперервних змінних. Кількість кластерів: 3} \\
\cline { 2 - 6 } & \multicolumn{3}{|c|}{ Загальна кількість спостережень: 25 } \\
\hline Засуджені до позбавлення волі & 1,70542 & 2 & 22,29458 & 22 & 0,84144 & 0,444496 \\
\hline Засуджені за тяжкі та особливо тяжкі злочини & 11,90831 & 2 & 12,09169 & 22 & 10,83318 & 0,000531 \\
\hline Засуджені за злочини середньої тяжкості & 12,14021 & 2 & 11,85979 & 22 & 11,26008 & 0,000429 \\
\hline Засуджені за злочини невеликої тяжкості & 11,26107 & 2 & 12,73893 & 22 & 9,72387 & 0,000942 \\
\hline Накладено штраф & 14,40249 & 2 & 9,59751 & 22 & 16,50714 & 0,000042 \\
\hline Призначено громадські роботи & 7,48746 & 2 & 16,51254 & 22 & 4,98785 & 0,016354 \\
\hline Застосовано арешт & 10,71274 & 2 & 13,28726 & 22 & 8,86866 & 0,001498 \\
\hline Застосовано обмеження волі & 0,20620 & 2 & 23,79380 & 22 & 0,09533 & 0,909447 \\
\hline Звільнено від покарання з випробуванням & 14,93945 & 2 & 9,06055 & 22 & 18,13730 & 0,000022 \\
\hline Призначено покарання за сукупністю & 2,64106 & 2 & 21,35894 & 22 & 1,36016 & \multirow{2}{*}{0,277366} \\
\hline злочинів та вироків & & & & & \\
\end{tabular}

важно західні та північні регіони 3 сільськогосподарською орієнтацією економіки. Виняток становить лише Донецька область, але на цей факт можна не зважати, бо йдеться лише про невелику частину підконтрольної Україні території, і тому дані по регіону можуть бути некоректними. До другого кластеру увійшли три регіони, які розташовані в центральній Україні і $€$ надзвичайно успішними в економічному аспекті. До третього кластеру увійшли переважно промислово-розвинені регіони, де саме велика кількість промислових міст $€$ осередками поширених видів злочинності. Тобто можемо припустити, що на структуру злочинності відчутний вплив має панівний спосіб виробництва в регіоні.

3 метою проведення більш глибокого кримінологічного дослідження, а саме виявлення міри залежності показників судової статистики від предикторів іншого характеру, додаємо деякі економічні та соціально-демографічні показники та проводимо канонічний аналіз кореляцій.

Обрані для аналізу показники переважно відносні, але деякі представлені в абсолютних величинах. Усі дані взяті за 2019 рік: 1) питома вага населення у віці кримінальної активності; 2) питома вага міського населення; 3) коефіцієнт смертності на 100000 населення; 4) кількість зареєстрованих шлюбів на 1000 населення; 5) кількість розірваних шлюбів на 1000 населення; 6) наявний дохід у розрахунку на 1 особу; 7) викиди забруднюючих речовин в атмосферне повітря (тис. т.); 8) кількість абонентів інтернету по регіонах (тис. осіб) [8].

Перші шість показників є традиційними економічними та соціально-демографічними предикторами злочинності. Фактор «Викиди забруднюючих речовин в атмосферне повітря» наводиться в тис. т. і включає кількість викидів від стаціонарних джерел забруднення у 2019 році. Цей фактор включено до аналізу з метою перевірки гіпотези про кореляційну залежність рівня злочинності (або її окремих видів) від забрудненості атмосферного повітря. Що ж стосується фрактору «Кіль- кість абонентів інтернету по регіонам», то йдеться про доступ населення до інформації. Включення в аналіз цього фрактору має перевірити гіпотезу про вплив на злочинність (або ії окремі види) сучасної інформатизації суспільства. Всі додані предиктори наведено в таблиці 6.

Об'єднаємо описувані показники 3 вище описаними показниками судової статистики в єдину таблицю та проведемо кореляційний аналіз за допомогою модулю Canonical Analysis в STATISTICA. Отримані показники внесені до таблиці 7

У результаті фрактори «Населення у віці кримінальної активності» та «Коефіцієнт смертності» не мають жодної кореляційної залежності з показниками судової статистики. Фактор «Питома вага міського населення» має дві значущі кореляції: додатна - з показником «Питома вага засуджених за злочини середньої тяжкості»; від'ємна - $з$ показником «Питома вага засуджених за злочини невеликої тяжкості». Можливе пояснення першої кореляції зводиться до того, що значна кількість засуджених за злочини середньої тяжкості належить саме до міського населення. Щодо другої від'ємної кореляційної залежності, то вона є більш значущою та дозволяє припустити, що велика кількість засуджених за злочини невеликої тяжкості належать до представників сільського населення.

3 фактором «Кількість зареєстрованих шлюбів» додатну кореляцію має показник «Питома вага засуджених за злочини середньої тяжкості» та від'ємну кореляцію має показник «Призначено громадські роботи». Маємо обґрунтоване припущення, що злочини одружених осіб частіше за інших належать саме до категорії злочинів середньої тяжкості, але такий вид покарання, як громадські роботи, до них застосовується рідше.

У той же час фактор «Кількість розірваних шлюбів» має додатну кореляцію із показником «Питома вага засуджених до позбавлення волі» та від'ємну кореляцію з показником «Питома вага засуджених за злочини невеликої тяж- 


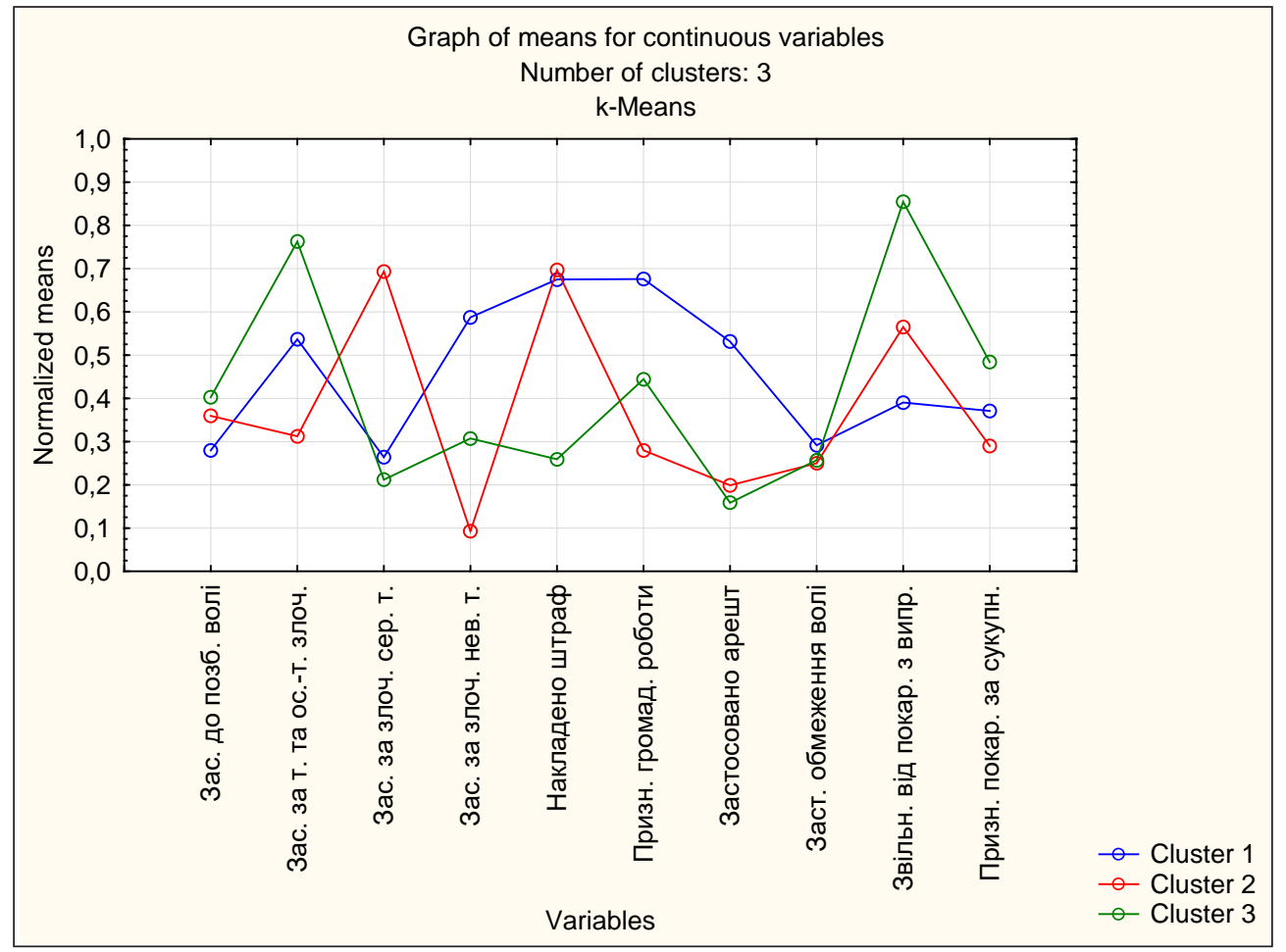

Рис. 1. Графрік середніх для змінних кластерного аналізу

Таблиця 6

Окремі економічні та соціально-демографічні показники у 2019 році за регіонами України

\begin{tabular}{|c|c|c|c|c|c|}
\hline № & Регіони України & $\begin{array}{c}\text { Питома вага } \\
\text { населення увіці } \\
14-65 \text { р., \% }\end{array}$ & $\begin{array}{c}\text { Питома вага насе- } \\
\text { лення, що прожи- } \\
\text { ває в містах, \% }\end{array}$ & $\begin{array}{c}\text { Коефіцієнт } \\
\text { смертності } \\
\text { на } 100000 \text { осіб } \\
\end{array}$ & $\begin{array}{l}\text { Кількість зареє- } \\
\text { строваних шлюбів } \\
\text { на } 1000 \text { населення }\end{array}$ \\
\hline A & Б & 1 & 2 & 3 & 4 \\
\hline 1 & АР Крим & - & - & - & - \\
\hline 2 & Вінницька & 68,9 & 36,4 & 1561,1 & 6,0 \\
\hline 3 & Волинська & 69,2 & 36,9 & 1293,6 & 5,9 \\
\hline 4 & Дніпропетровська & 69,9 & 58,7 & 1597,4 & 6,3 \\
\hline 5 & Донецька & 69,4 & 63,0 & - & - \\
\hline 6 & Житомирська & 69,4 & 41,7 & 1640,6 & 5,9 \\
\hline 7 & Закарпатська & 70,2 & 25,9 & 1239,7 & 6,0 \\
\hline 8 & Запорізька & 70,2 & 54,2 & 1640,7 & 5,7 \\
\hline 9 & Івано-Франківська & 70,7 & 44,0 & 1283,0 & 5,6 \\
\hline 10 & Київська & 69,2 & 44,0 & 1612,6 & 7,2 \\
\hline 11 & Кіровоградська & 68,8 & 44,1 & 1656,2 & 5,1 \\
\hline 12 & Луганська & 70,2 & 61,2 & - & - \\
\hline 13 & Львівська & 70,4 & 43,4 & 1314,3 & 6,0 \\
\hline 14 & Миколаївська & 70,4 & 48,3 & 1519,2 & 5,8 \\
\hline 15 & Одеська & 69,2 & 46,5 & 1397,6 & 7,0 \\
\hline 16 & Полтавська & 69,9 & 44,1 & 1653,5 & 5,8 \\
\hline 17 & Рівненська & 69,1 & 33,9 & 1228,9 & 5,8 \\
\hline 18 & Сумська & 71,0 & 49,6 & 1622,5 & 5,0 \\
\hline 19 & Тернопільська & 70,6 & 32,6 & 1420,0 & 5,5 \\
\hline 20 & Харківська & 71,1 & 58,2 & 1531,7 & 6,3 \\
\hline 21 & Херсонська & 70,3 & 42,7 & 1554,0 & 5,9 \\
\hline 22 & Хмельницька & 69,3 & 40,9 & 1543,8 & 5,5 \\
\hline 23 & Черкаська & 69,5 & 40,2 & 1647,9 & 5,5 \\
\hline 24 & Чернівецька & 70,3 & 31,2 & 1231,6 & 5,8 \\
\hline 25 & Чернігівська & 68,8 & 46,4 & 1877,2 & 5,2 \\
\hline 26 & м. Київ & 69,4 & 70,6 & 1135,7 & 9,5 \\
\hline 27 & м. Севастополь & - & - & - & - \\
\hline 28 & Всього по Україні & 69,8 & 48,9 & 1472,7 & 6,3 \\
\hline
\end{tabular}


Продовження таблиці 6

\begin{tabular}{|c|c|c|c|c|c|}
\hline № & Регіони України & $\begin{array}{c}\text { Кількість розірва- } \\
\text { них шлюбів на } \\
1000 \text { населення }\end{array}$ & $\begin{array}{c}\text { Наявний дохід } \\
\text { у розрахунку } \\
\text { на } 1 \text { особу }\end{array}$ & $\begin{array}{c}\text { Викиди забруд- } \\
\text { нюючих речовин } \\
\text { в атмосферне } \\
\text { повітря, тис. т. }\end{array}$ & $\begin{array}{c}\text { Кількість абонен- } \\
\text { тів Інтернету по } \\
\text { регіонах, тис. осіб }\end{array}$ \\
\hline A & 5 & 5 & 6 & 7 & 8 \\
\hline 1 & АР Крим & - & - & - & - \\
\hline 2 & Вінницька & 3,6 & 64729 & 99,7 & 102,3 \\
\hline 3 & Волинська & 2,9 & 52879 & 5,3 & 64,1 \\
\hline 4 & Дніпропетровська & 4,1 & 87130 & 576,9 & 268,1 \\
\hline 5 & Донецька & - & 39141 & 773,5 & 173,9 \\
\hline 6 & Житомирська & 3,6 & 61961 & 12,7 & 100,1 \\
\hline 7 & Закарпатська & 2,3 & 47495 & 3,7 & 69,5 \\
\hline 8 & Запорізька & 4,0 & 75407 & 173,4 & 158,0 \\
\hline 9 & Івано-Франківська & 3,1 & 55537 & 205,0 & 102,4 \\
\hline 10 & Київська & 4,1 & 75146 & 84,4 & 143,1 \\
\hline 11 & Кіровоградська & 3,6 & 58290 & 12,8 & 65,0 \\
\hline 12 & Луганська & - & 24477 & 37,4 & 66,1 \\
\hline 13 & Львівська & 2,6 & 65691 & 88,9 & 235,6 \\
\hline 14 & Миколаївська & 3,8 & 63685 & 12,1 & 160,6 \\
\hline 15 & Одеська & 3,7 & 72805 & 33,1 & 1116,4 \\
\hline 16 & Полтавська & 4,0 & 71627 & 51,0 & 142,5 \\
\hline 17 & Рівненська & 2,6 & 54183 & 9,9 & 69,2 \\
\hline 18 & Сумська & 3,6 & 65310 & 21,7 & 80,4 \\
\hline 19 & Тернопільська & 3,0 & 49843 & 9,4 & 108,8 \\
\hline 20 & Харківська & 4,1 & 65534 & 106,5 & 175,4 \\
\hline 21 & Херсонська & 3,7 & 57110 & 17,8 & 94,1 \\
\hline 22 & Хмельницька & 3,8 & 58008 & 20,3 & 85,7 \\
\hline 23 & Черкаська & 3,8 & 58808 & 51,8 & 75,3 \\
\hline 24 & Чернівецька & 3,2 & 48255 & 2,4 & 66,2 \\
\hline 25 & Чернігівська & 3,8 & 58904 & 27,5 & 77,8 \\
\hline 26 & м. Київ & 3,8 & 165054 & 22,3 & 1714,9 \\
\hline 27 & м. Севастополь & - & - & - & - \\
\hline 28 & Всього по Україні & 3,6 & 3815511 & 2459,5 & 26380,5 \\
\hline
\end{tabular}

кості». Це дозволяє припустити, що збільшення розлучень $€$ показником морально нездорової частини суспільства і загалом тягне збільшення осіб, засуджених до позбавлення волі. Не можна також забувати і про зворотній вплив цих фракторів. У цей висновок вкладається і тенденція зменшення в цій частині злочинів невеликої тяжкості (їх скоєння не тягне за собою позбавлення волі).

Фінансовий фрактор «Наявний дохід у розрахунку на 1 особу» має значну додатну кореляцію з показником «Питома вага засуджених за злочини середньої тяжкості», що є передбачуваним з погляду значної кількості злочинів проти власності в структурі злочинів середньої тяжкості. Адже саме ці злочини є найбільш чутливими до економіко-фрінансових фракторів. Фактор доходів також має від'ємну кореляцію з показником «Питома вага засуджених за злочини невеликої тяжкості». Поясненням цьому є зростання рівня загальної напруженості в суспільстві у періоди фрінансових криз, що своєю чергою призводить до зростання дрібних правопорушень та злочинів невеликої тяжкості.
Експериментальний фактор «Викиди забруднюючих речовин» має дві додатні кореляції: з показником «Питома вага засуджених до позбавлення волі» та з показником «Призначено покарання за сукупністю злочинів». Це дозволяє висунути припущення про вплив забруднення на кількість злочинів середньої тяжкості, тяжких і особливо-тяжких, а також і про його зв'язок із систематичним заняттям злочинною діяльністю. Однак такі висновки потребують більш ґрунтовних досліджень, бо наявний зв'язок може бути пов'язаний не з самими забруднюючими викидами, а з місцями розташування стаціонарних джерел забруднення в промислових осередках регіонів, де діють також і інші кримінально провокуючі фактори.

Фактор «Кількість інтернет користувачів» має значущу від'ємну кореляцію з показником «Питома вага осіб, яким призначено громадські роботи». Це дозволяє висунути припущення, що громадські роботи як вид покарання призначаються переважно молодим відносно здоровим людям. Ця ж сама категорія $є$ активними 
Кореляційна матриця

Таблиця 7

\begin{tabular}{|c|c|c|c|c|c|c|c|c|c|c|}
\hline $\begin{array}{c}\text { Ймовірні предиктори } \\
\text { злочинності }\end{array}$ & \multicolumn{7}{|c|}{ Показники судової статистики } \\
\cline { 2 - 11 } & Var 1 & Var 2 & Var 3 & Var 4 & Var 5 & Var 6 & Var 7 & Var 8 & Var 9 & Var 10 \\
\hline $\begin{array}{c}\text { Населення у віці } \\
\text { кримінальної активності }\end{array}$ & 0,089 & $-0,165$ & 0,002 & 0,236 & 0,073 & 0,078 & 0,208 & 0,438 & $-0,243$ & 0,082 \\
\hline $\begin{array}{c}\text { Питома вага міського } \\
\text { населення }\end{array}$ & 0,449 & $-0,261$ & 0,586 & $-0,604$ & $-0,165$ & $-0,235$ & 0,012 & $-0,024$ & 0,003 & 0,383 \\
\hline Коефіцієнт смертності & 0,260 & 0,210 & $-0,060$ & $-0,198$ & $-0,414$ & 0,420 & 0,224 & $-0,068$ & 0,089 & 0,432 \\
\hline $\begin{array}{c}\text { Кількість } \\
\text { зареєстрованих шлюбів }\end{array}$ & 0,179 & $-0,370$ & 0,592 & $-0,463$ & 0,135 & $-0,655$ & $-0,297$ & $-0,112$ & 0,066 & $-0,288$ \\
\hline Кількість розірваних шлюбів & 0,523 & $-0,145$ & 0,439 & $-0,524$ & $-0,324$ & $-0,020$ & 0,100 & $-0,139$ & 0,056 & 0,308 \\
\hline Наявний дохід на 1 особу & 0,224 & $-0,487$ & 0,769 & $-0,590$ & 0,135 & $-0,482$ & $-0,156$ & $-0,066$ & $-0,039$ & 0,012 \\
\hline $\begin{array}{c}\text { Викиди } \\
\text { забруднюючих речовин }\end{array}$ & 0,671 & 0,158 & 0,029 & $-0,270$ & $-0,441$ & $-0,134$ & $-0,119$ & 0,027 & 0,114 & 0,654 \\
\hline $\begin{array}{c}\text { Кількість } \\
\text { інтернет-користувачів }\end{array}$ & 0,073 & $-0,279$ & 0,499 & $-0,438$ & 0,185 & $-0,596$ & $-0,147$ & $-0,183$ & 0,025 & $-0,261$ \\
\hline
\end{tabular}

користувачами інтернету в домашніх умовах. Таким чином, молоді люди, схильні до злочинних дій, які активно користуються інтернетом вдома, або не мають часу на злочинні прояви або достатньо реалізують свої нахили у віртуальному житті (спілкування в соцмережах, комп'ютерні ігри тощо). Отже, інтернет-користування в сучасному контексті злочинних проявів відіграє швидше запобіжну роль, ніж кримінально провокуючу.

Висновки. У результаті проведеного дослідження за допомогою кластерного аналізу судо- вої статистики дістала наукове підтвердження гіпотеза, що на структуру злочинності в Україні відчутний вплив здійснює панівний спосіб виробництва в регіоні. Для з'ясування міри впливу окремих факторів за допомогою канонічного аналізу було виявлено декілька з них, що корелюють з рівнем та визначають структуру злочинності регіону. До таких фракторів варто віднести: кількість зареєстрованих та розірваних шлюбів, дохід у розрахунку на одну особу, викиди забруднюючих речовин, кількість інтернет-користувачів у регіоні.

\section{Список використаних джерел:}

1. Шкута О.О. Теоретико-прикладні засади функціонування кримінально-виконавчої системи України : дис. ... д-ра юрид. наук. Запоріжжя, 2018. 491 с.

2. Alwee, Razana \& Shamsuddin, Siti Mariyam \& Sallehuddin, Roselina. (2015). Modeling of violent crime rates with economic indicators using hybridization of grey relational analysis and support vector regression. Jurnal Teknologi. 76. 10.11113/jt.v76.3899. pp. 229-238.

3. Rattner, Arye. Social Indicators and Crime Rate Forecasting. Social Indicators Research, vol. 22, no. 1, 1990. JSTOR. Accessed 11 Aug. 2020. pp. 83-95. URL: www.jstor.org/stable/27520805.

4. Carranza Romero, Juan Esteban, González Espitia, Carlos Giovanni, \& Bocanegra Ochoa, Gipsy Eliana. (2020). Efecto de la actividad economica sobre la violencia homicida: nueva evidencia a partir de datos de panel en Colombia. Cuadernos de Economía, 39 (79), pp. 355-388. URL: https://dx.doi.org/10.15446/cuad.econ.v39n79.43049.

5. Larchenko Maryna. Modeling and Predicting Criminal Behaviour. World and Ukrainian Experience. LAP LAMBERT Academic Publishing, 2020. 508 p.

6. Судова влада України. Розділ: судова статистика. URL: https://court.gov.ua/inshe/sudova_statystyka/ rik_2019 (станом на 16.08.2020);

7. Стан здійснення правосуддя у кримінальних провадженнях та справах про адміністративні правопорушення судами загальної юрисдикції у 2019 році. Верховний Суд. 105 c. URL: https://supreme.court.gov.ua/userfiles/media/ Zbirka_analit_tablic_2019.pdf (станом на 16.08.2020).

8. Державна служба статистики. Офіційний сайт. Розділ: статистична інформація. URL: http://www.ukrstat.gov. ua/ (станом на 16.08.2020). 


\author{
Мельник Я.Я., \\ доктор юридичних наук, старший науковий співробітник \\ Інститут права \\ Київського національного університету імені Тараса Шевченка, \\ профресор кафедри державно-правових та галузевих дисциплін \\ Київського університету права Національної академії наук України, \\ адвокат \\ ORCID: 0000-0003-1937-6772
}

\title{
БЕЗПЕКА ТЕКСТОВОЇ ІДЕОЛОГІЇ СОЦІАЛЬНОГО ПРАВА: АНТРОПОЛОГО-КОМУНІКАТИВНИЙ АСПЕКТ
}

\section{SECURITY OF THE TEXT IDEOLOGY OF SOCIAL LAW: ANTHROPOLOGICAL-COMMUNICATIVE ASPECT}

\begin{abstract}
У статті розглядаються проблеми ідеології соціального права через призму текстового його виразу. Аналізується антрополого-комунікативний аспект буття соціального права, його розвитку та трансформації. На підставі цього автором розкриваються особливості соціального права, його зміни як знакового феномену права. Піднімаються проблеми сенсово-семіотичного характеру соціального права, змісту, який стосується пізнання права інтерпретатором та правозастосувачем смислових сенсів та аксіологічного навантаження на соціальні права та соціальне право загалом. У процесі дослідження автором статті доводиться, що конфлікти у праві зазвичай пов'язані із антрополого-комунікативним аспектом пізнання соціального права та соціальних прав, адже змінюються стиль викладу та юридична техніка права як знакової системи. Це пов’язано із тим, що змінюється насамперед природно-правове розуміння соціального права, змінюється й сфера та вид комунікації соціальних прав. До певної міри атрополого-комунікативний аспект соціального права є ланкою соціальної безпеки, а тому ідеологія соціального права повинна бути націлена на єдине та однозначне розуміння юридичних текстів соціально-правового характеру, дбати про максимальну уніфікацію таких текстів як на рівні нормативно-правових актів, так і на рівні смислових знаків для соціально незахищених та соціально вразливих верств населення. Як наслідок, автором доводиться, що антропологічна суть соціального права в комунікативно-антропологічному аспекті вказує на перманентний рух, що призводить до видозмінення соціальної доктрини права, вимагає пристосовувати нормативно правовий акт до реалій сьогодення (правової реальності). Саме такий підхід, на думку автора, буде сприяти забезпеченню належної комунікації між законодавцем та користувачем прав, а відтак наближати до зменшення випадків порушення соціальних прав, розвитку правової культури, ефективності реалізації прав та безпеки соціального правопорядку в контексті концепції сталого розвитку суспільства. Автор доходить висновку, що ідея текстового виразу соціального права сприятиме розвитку вітчизняної правової доктрини, забезпечить пришвидшення адаптаційного процесу соціального права в євроінтеграції.
\end{abstract}

Ключові слова: ідеологія сочіального права, сочіальна безпека, сочіальні права, антропологія права, постмодернізм права, філософія сочіального права

The article considers the problems of the ideology of social law through the prism of its textual expression. The anthropological-communicative aspect of the existence of social law, its development and transformation is analyzed. Based on this, the author reveals the features of social law, its changes as a significant phenomenon of law. There are problems of semantic-semiotic nature of social law, the content of which concerns the knowledge of law by the interpreter and law enforcer of semantic meanings and the axiological burden on social rights and social law in general. In the course of the research, the author of the article argues that conflicts in law are often related to the anthropological and communicative aspect of knowledge of social law and social rights, as the style of presentation and legal technique of law as a sign system change. This is due to the fact that the natural and legal understanding of social law is changing, and the scope and type of communication of social rights is changing. To some extent, the anthropological-communicative aspect of social law is a link of social security, and therefore the ideology of social law should be aimed at a single and unambiguous understanding of legal texts of socio-legal nature, to ensure maximum unification of such texts, both at the level of regulations and and at the level of semantic signs for socially vulnerable and socially vulnerable segments of the population. As a result, the author argues that the anthropological essence of social law in the communicative-anthropological aspect indicates a permanent movement that leads to changes in the social doctrine of law, requires adapting the legal act to the realities of today (legal reality). This approach, from the author's point of view, will help ensure proper communication between the legislator and the user

Випуск 1 (32), 2020 
of rights, and thus approach the reduction of social rights violations, development of legal culture, effective implementation of rights and security of social law and order in the context of sustainable development. The author comes to the conclusion that the idea of textual expression of social law will promote the development of domestic legal doctrine, will accelerate the adaptation process of social law in European integration.

Key words: ideology of social law, social security, social rights, anthropology of law, postmodernism of law, philosophy of social law

Актуальність теми дослідження. Будь-який закон як вираз права повинен бути чітким та зрозумілим під час його інтерпретації, а соціальний закон до того ж має містити достатню інформацію про його соціальне спрямування, призначення, застосування. Власне, містити однозначний текстовий вираз.

Мистецтво розуміння юридичних текстів нерозривно пов'язане із антрополого-комунікативним аспектом, який проявляється в соціальній дійсності. Завдяки такій властивості права окреслюється й ступінь відповідності соціальної спрямованості держави ідеям соціального права. Із урахуванням прояву численних соціальних кризових фракторів (природніх катаклізмів, стихійних лих, урбанізації суспільства, проблем медико-соціального, житлово-комунального, освітньо-соціального чи то глобалізаційно-технологічного характеру) відчувається дихотомія між цими факторами та діючою концепцією ідеології соціального права. Внаслідок чого насамперед відбуваються потужні зсуви право-матерії у бік численних розбіжностей із правовою дійсністю, соціальними потребами, як, власне, із станом соціального законодавства як необхідним інструментом, що покликаний за своєю ідеєю вчасно долати ті чи інші перепони у правовому регулюванні соціальних відносин. Це і вказує на необхідність перегляду ідеологічної моделі соціального права в державі, який, на нашу думку, слід розпочинати із антропологокомунікативного наративу структури соціального права.

Аналіз останніх публікацій та досліджень. Проблеми дослідження соціального права у сучасний постмодерний період зумовлені численними факторами соціальних ризиків та конфрліктів. Серед дослідників, праці яких мають вплив на фрормування ідеології соціального права, можливо відмітити вітчизняних, зокрема С.В. Бобровник, С.П. Головатого, В.В. Завальнюка, Т.А. Занфірову, М.І. Іншина, Н.М. Оніщенко, Д.Г. Севрюкова, Н.М. Пархоменко, Я.І. Пасько, В.І. Щербину, та закордонних - Річарда А. Познера, Ганса Кельзена, Браяна Таманагу тощо.

Проте, аналізуючи питання текстової ідеології соціальної права як певного елементу його безпеки, варто звернути увагу на ряд проблем, які пов'язані із текстовим її виразом у соціальному праві. Це і спонукає нас до постановки проблеми саме у такому ключі.

Мета статті - дослідження антрополого-комунікативного аспекту безпеки текстової ідеології соціального права. Вирішення цього питання надасть можливість доповнити доктрину соціального права ідеологічними висновками, відстежити ключові моменти забезпечення соціальних прав та найголовніше - розкрити проблему текстового посилу як знакового еквіваленту юридично-значимої інфрормації для ефективної комунікації між суб'єктами права. А відтак показати потенціал соціального права в текстовому / семіотичному еквіваленті.

Виклад основного матеріалу. Аналізуючи основні концептуальні дослідження й публікації стосовно соціального права та соціальної держави, варто насамперед звернути увагу на стан розвитку правової доктрини.

Так, у теорії права панує думка про те, що соціальна держава - це та держава, політика якої спрямована насамперед на створення умов, що забезпечують гідне життя та вільний розвиток людини. Вона характеризує за своєю суттю могутній потенціал, що дозволяє здійснити заходи з перерозподілу доходів, не зачіпаючи положення власників; їй притаманна соціально орієнтована структура економіки, що виражається в існуванні різних форм власності із значною часткою власності держави в суспільно необхідних сферах господарства; а також має соціальну спрямовану політику та цілі (встановити загальні блага), розвинуте правове регулювання в соціальній сфрері (з виділенням галузей трудового права, права соціального забезпечення, медичного права тощо). їй притаманні такі соціальні функції: підтримка соціально незахищених категорій населення (через систему пенсій, соціальних виплат і допомоги); створення можливостей для вільної реалізації трудового та інтелектуального потенціалу громадян держави; охорона праці та здоров'я людей; підтримка сім'ї, материнства батьківства і дитинства; залагоджування соціальної нерівності шляхом перерозподілу доходів між різними соціальними шарами через оподаткування, державний бюджет, спеціальні соціальні програми; заохочення благодійної діяльності; турбота про збереження соціального миру в суспільстві, системи соціального партнерства; участь в реалізації міждержавних соціальних програм, вирішення загальнолюдських проблем [20, с. 72-73]. За природно-правового підходу сутність права розкривається не тільки у загальнолюдському змісті, алей й у закріпленні цінностей індивідуальної свободи, незалежності і безпеки [20, с.97]. Зазвичай ідея права в безпековому аспекті розкривається винятково в писаному праві, тобто у відповідних законах та підзаконних норматив- 
но-правових актах, норми яких можуть прямо вказувати на безпековий характер ідеї соціального права. Очевидним тут $є$ й те, що безпека як френомен вже є сформованою константою, пізнання якої відбувається на очевидних конкретних образах та праобразах про найкращі блага, про свободу та ії цінність; вона, безпека, за своєю суттю відображає загальнолюдський, соціальний характер та потенціал самого права, цінність держави для людини, як і саме право для людини.

На важливості універсалізму у дослідженнях права за антропологічним сприйняттям наголошує С.П. Головатий. На його думку, саме цей підхід у сприйнятті людських прав дає змогу робити наголос нам на універсальних коренях права, які подекуди можуть нівелюватись. Адже критицизм ідеї універсальності людських прав у культурах світу подається до певної міри як просто міф [8, с. 422-423].

В.В. Завальнюк, досліджуючи проблематику юридичної антропології в контексті міфів позитивного права, припускається думки, що аби розпочати вирішення мети проблеми права, необхідно розпочинати не стільки із соціології права, скільки із антропології права. На його думку, вивчення правознавства повинно розпочинатися із нижчого рівня, так би мовити із мікроправознавства як наукового дослідження властивого людині прояву генезису права, аналізу його першоджерел, причин і його умов появи та розвитку [1, с. 45]. Вчений фокусує свій науковий пошук на тому, що антропологія права як концепція потребує методологічного антропоцентризму, оскільки саме це надає можливість проникнути в сутність права через пізнання природи людини. А з іншого боку, такий підхід допоможе зрозуміти природу людини через пізнання сутності права [1, с. 46]. Цікавим у позиції вченого $є$ й те, що «...сучасні ліберальні суспільства офріційно надають великого значення індивіду як неподільному поняттю, на відміну від традиційних суспільств, і вкладають у це поняття такі категорії: особистість (у фрізичному, юридичному і моральному змісті), воля, власність і відповідальність. Особистість має в розпорядженні права й обов'язки, зумовлені частково законом, частково нею самою. Щоб індивід міг використовувати свої права й обов'язки, він повинен мати у своєму розпорядженні волю, засновану на його волі (теорія автономії волі); сукупність воль індивідів узаконюються за допомогою принципу консенсусу. Що стосується поняття власності, то воно відповідає дії принципу волі на речі: власність узаконює владу індивіда стосовно речей. Воля, воля й власність мають противагу в особі відповідальності, що відповідно до нашого права має персональний характер, тоді як у традиційних суспільствах існує інша тенденція..» [1, с. 48].

Водночас, ведучи мову про соціальні права як права другого покоління, що покликані у своїй ідеї забезпечити особу захистом її життєво необ- хідних матеріальних потреб (право на освіту, на працю, на житло тощо), важливо звернути увагу на прояв їх особливостей в ідеї засновків.

Так, особливістю соціальних прав $є$ те, що вони завжди вимагають певної державної дії, аби їх можна було б забезпечити, а саме: вони потребують певного призначення ресурсів або їх перерозподілу. Такі права можуть зазнавати обґрунтованих обмежень, якщо вони вступають у конфлікт із питанням економічного благополуччя суспільства [8, с. 299]. Доволі показовим у такому разі є два рішення Конституційного Суду України. Предметно до дослідження їх змісту та наслідків вдався вітчизняний науковець-правник Ю. Барабаш. Зокрема, вчений відмічає, що «...у 2010-2011 роках під впливом цілої низки обставин відбулась докорінна зміна у доктринальних підходах Суду до питання гарантування соціальних прав. Йдеться про два славнозвісні рішення від 26 грудня 2011 року № 20-рп/2011 та від 25 січня 2012 року № 3-рп/2012, у яких Суд чи не вперше віддав перевагу принципу «фінансової безпеки» (точніше, «збалансованості державного бюджету») на противагу неможливості перегляду системи гарантій соціальних прав, заперечивши в останніх (прав) характер абсолютних ... [3]. Доволі схожу тенденцію можливо відстежити вже за часом пізніше, а саме у сучасних умовах, де з огляду на заходи, що встановлені державою задлядолання пандемії, викликаної «COVID-19», були прийняті ряд дисфункційних нормативно-правових актів стосовно соціального права, що слугували обмеженням для ряду соціальних прав.

Так, відповідно до ст.ст. 28, 30 Закону України «Про забезпечення санітарного та епідемічного благополуччя населення» «...доручено ввести обмежувальні заходи на території міста Києва з 00 год. 00 хв. 12.03.2020 до 31.03.2020 року, а зокрема: призупинити освітній процес у закладах загальної середньої, дошкільної, позашкільної, професійної (професійно-технічної) освіти усіх типів, форм власності міста Києва; призупинити освітній процес у вищих навчальних закладах; обмежити проведення спортивних заходів на території м. Києва; призупинити роботу театрів, кінотеатрів, музеїв, культурно-масових заходів тощо; призупинити роботу розважальних центрів; призупинити роботу розважальних зон в шопінг-молах; забезпечити обмеження проведення масових заходів на території м. Києва (більше 60 осіб), до участі в заходах допускати лише осіб, які пройшли термометрію; забезпечити недопущення до роботи працівників підприємств та установ міста Києва з ознаками інфекційного захворювання...» [14]. Як наслідок, сьогодні численні ЗМІ рясніють різного роду фактами, які вказують про неоднозначне розуміння та застосування закону про боротьбу 3 «COVID-19», а саме стосовно соціального, 
трудового чи то адміністративного права. Відповідно, питання забезпечення належного розуміння соціальних можливостей, соціальних прав людини у побуті у такий період залишається відкритим. Проблема насамперед постає в оптимізаційно-інформаційному сенсі та певною мірою в семіотичному, знаковому. Адже не зрозуміло, у яких публічних місцях та у якій формі слід дотримуватись соціального права, соціальної безпеки.

Враховуючи можливі фактори амбівалентності розуміння юридичного тексту у суспільстві, більш доцільно вести дискусію про критичне, аніж належне. Це зумовлено тим, що такі обставини вказують на очевидний процес (ре)соціалізації права, власне, прояву функціональної текстової деменції соціального права.

Свого часу Н.M. Оніщенко та Н.М. Пархоменко, досліджуючи проблеми правової системи і соціальної держави в аспектах їх співвідношення, не без підстав зазначали, що в незалежній Україні спостерігалася слабка діяльність держави, що проявилася у невирішенні ряду саме ключових соціальних проблем громадян, які нерідко призводили до гострих соціальних конфліктів, порушення прав громадян, закріплених у Конституції України, тощо. За таких обставин вчені припускалися думки, що у такій постановці проблеми має вже йтися про відповідальність держави за бездіяльність їі органів і посадових осіб, за грубі порушення конституційних прав. Проте, на їх думку, цього як раз не відбувається, а якщо і відбувається, то надто рідко. Як наслідок, вчені вказують на прояв почуття безкарності, вседозволеності в окремих державних урядовців і в держави загалом $[21$, с. 40]. За таких обставин стає очевидним, що в країні постійно діють ряд спеціальних соціальних законів, які нівелюються. До того ж діють норми Конституції України як норми прямої дії, а «соціальна деменція» щоразу поглиблюється, не вирішується. Це дає підстави вести мову не про що інше, як про зміну ідеології в державі соціального права, як і його функціонального покликання.

Тут цілком доречними видаються критичні зауваги Ричарда А. Познера стосовно ефективності норм права. Зокрема, вчений-дослідник, здійснюючи економічний аналіз права, зазначає, що норми є ефективнішими, коли їх дотримується невелика група, адже операції, що повторюються, не тільки зменшують вартість остракізму для осіб, що когось осуджують, але й полегшують завдання визначити, хто саме порушує норми, адже такі операції $є$ більш поширеними в невеликих соціальних групах. «Ефективність норм підвищується, - пише вчений, - зі зростанням вартості остракізму як такого. Обидві умови (невеликі групи та висока вартість остракізму), ймовірно, виконувалися в ізольованих суспільствах. Третя умова, яка сприяє ефективності норм - це статичність соціальної групи. До того ж проблема безкоштовного користування цінностями, що виникає через відсутність централізованої влади, котра могла б створити або замінити норми, робить поважні зміни норм дуже нелегкими та коштовними. Зазвичай люди дотримуються наявних норм унаслідок почуття провини або сорому. А засвоєння норм через призвичаєння до них може здатися дуже ефективним, тому що при цьому зменшуються витрати на досягнення згоди. 3 огляду на це намагання суспільства втрутитися вже на стадії формування норм включає такі дії, як шкільне виховання дітей у дусі терпимості, небайдужості до інших, послуху до закону й поваги до прав інших людей. Тому рівень освіченості суспільства $€$ позитивною функцією. Саме право, як вважають юристи, і є подібним до освіти, є потенційно значущим як механізм формування (а не як гарант дотримання) норм» [22, с. 349-352].

Отже, комплекс проблем, що назрів в ідеології соціального права, спонукає нас вдатись до більш детального дослідження феномену «ідеології». Тут доцільно звернути увагу й на семантичне навантаження цього терміну.

Так, ведучи мову про ідеологію соціального права, насамперед важливо зазначити, «що будь-яке людське пізнання починається зі споглядань, проходить крізь поняття і закінчується в ідеях» [29, с. 146]. Водночас будь-яка «ідея» $\epsilon$, по суті, формою осягнення дійсності в думці, яка і включає усвідомлення мети та способу подальшого пізнання, а також перетворення світу. За своєю логічною структурою ідея $€$ певним видом поняття. Відмінність ідеї від звичайного поняття полягає в тому, що вона поєднує в собі об'єктивне знання про дійсність і суб'єктивну мету, спрямовану на зміну дійсності [28, с. 236]. А «ідеологія» $є$ нічим іншим, як сукупністю взаємопов'язаних ідей, уявлень та переконань, призначених об'єднувати людей заради спільного життя та спільних дій. Як свідчать історичні дослідження, ніколи не існувало суспільств без наявності в них певних світорозумінь і норм поведінки, тобто ідеологій-світоглядів [28, с. 235]. Відтак постає за доцільне проаналізувати певний комплекс уявлень про ідею права, її розвиток, «соціалізацію».

У фрілософії права виділяється поняття «ідеологія політична», під яким розуміється «...упорядкована за певною епістемологічною логікою система або сукупність політичних ідей, цінностей, поглядів, вірувань, настанов, ментальних моделей, символів, які репрезентують інтереси певної політичної групи й саму цю групу у сфері політичної свідомості, а також слугують інструментом захоплення або утримання державної влади...» [6, с. 289]. А у праві закріпилось поняття «ідеологія правова», під яким розуміють насамперед систему правових ідей, теорій, понять, норм, поглядів, заснованих на певних науко- 
вих і політичних знаннях та уявленнях. Одним із джерел виникнення правових ідей $€$ правова та і соціальна дійсність, а також практична діяльність людей, у процесі якої правові ідеї, погляди, соціальні та політичні вимоги народжуються, збагачуються, змінюються, концентруючи в собі результати юридичної практики. Водночас, як відмічається в юридичній енциклопедії, головна функція ідеології права - це вплив на формування і розвиток правової та іншої свідомості, світогляду та загальної культури індивідів, на зміцнення в суспільстві правових знань, піднесення престижу та авторитету держави, права та законодавства. Мета ідеології - сприяти фрормуванню уявлень, пропозицій, принципів, рекомендацій щодо удосконалення правових відносин, норм та інститутів [30, с. 659].

Тому цілком очевидно, що ідеологія правова тісно пересікається із соціальним та екологічним складником, вибудовуючи специфічний міждисциплінарний напрям. Адже, з іншого боку, філософія оперує такими поняттями, як «екологія», що походить від грецького (означає буквально оселя+слово), під яким розуміється сукупність наук про взаємодію екологічних систем (у тому числі й людини) із природнім середовищем. А сучасна екологія відображає комплекс дисциплін, у яких екологічний матеріал залучається для історії, соціології, етики, естетики, педагогіки а також юриспруденції [28, с. 189]. Екологічна свідомість - це усталена й усвідомлена система уявлень про стан природного довкілля, здатність (індивідуальна або колективна) до адекватного розуміння органічного зв'язку між людиною та природою і використання екологічних знань та переконань у всіх без винятку сферах практичної діяльності [28, с. 189]. Водночас, з огляду на те, що у двох попередніх поняттях відображається тісний та нерозривний взаємозв'язок між природою та людиною, групою людей, очевидним $є$ і наявність поняття «екологія соціальна». Під ним розуміється напрям екологічних досліджень, який вивчає процеси взаємодії між суспільством та природнім довкіллям, розробляє загальнонаукові засади раціонального природокористування [28, с. 190]. Спрямування на осмислення специфіки взаємовпливів соціальної, економічної, географічної, біологічної, культурної сфер, процесів коеволюції соціуму та природи, зокрема, впливу виробничої діяльності людини (чинників антропогенного походження) на довкілля, й навпаки - «олюдненої» природи на здоров'я та генофонд людських популяцій, зумовлює міждисциплінарний, інтегративний характер [28, с. 190].

Нині основними напрямами соціальної політики, а, відповідно, й основними соціальними функціями сучасної держави М.І. Іншин та B.I. Щербина пропонують визнати: гарантування оптимальних умов для забезпечення добробуту кожного члена суспільства; сприяння продуктивній зайнятості населення; постійний розвиток «людського потенціалу»; всебічна підтримка тих, хто вже чи ще не може себе належно забезпечити [12, с. 284].

В аспекті дослідження соціальної «ідеї» та «ідеології» важливо вказати на те, що ці поняття мають у своїй основі певний «ідеал». Цей термін походить від грецького та означає «первообраз» й тлумачиться, як уявлення про найвищу досконалість, котра як взірець, норма і мета визначає спосіб і характер діяльності людини або соціальної групи [28, с. 231].

Відтак соціальне право за визначенням / поняттям - це насамперед права людини і громадянина у соціальній сфері, що полягають у набутті соціальних благ, володінні, користуванні й розпорядженні ними та їхньому захисті або вчиненні певних дій у цій сфері [31, с. 560].

С.П. Головатий у своїх лекціях «Про людські права» розглядає соціальні права під призмою «ідеї» права, зазначаючи, що «...викладові сутності всіх ідей, концепції та теорій, що спричинилися до виникнення та розвитку людських прав...» [8, с. 46], чому і присвячує цикл лекцій. До прикладу, вчений розглядає ідею права з погляду ідеї «Закону Природи», розставляючи акценти на тому, що «закон» слід розуміти як той, що складається із принципів сутності людини homo sapiens - людини як розумної істоти [8, с. 47]. Сутність, очевидно, $€$ нічим іншим, як внутрішнім змістом буття людини.

На думку вченого, «розумна сутність людини» спричиняє наявність у неї певних обов'язків. Природа лише людину наділила здатністю оцінювати різні способи поведінки, а відтак за власним вибором віддавати перевагу якомусь одному із множини. С.П. Головатий, окрім цього, розглядає ідею права у період античності, зокрема, у вченнях Томаса Гобса, Джона Лока, Шарля-Луї Монтеск'є, Томи Аквінського, Гуго Гроція та інших [8, с. 47-63]. Жн.-Жк. Руссо розкриває до певної міри ідею того, що «божевілля не створює права» та ідею суспільного договору, що породжує державу [8, с. 130, 135]. Вже пізніше С.П. Головатий доволі слушно розкриває питання позитивістського погляду на ідею прав людини. Зокрема, зазначає, що позитивістський напрям у поглядах на теорію «природніх прав» представлений творчістю тих, хто стверджував, що така теорія - це ідеологія, що спрямована на підтримку самовираження лише середнього класу, який тільки-но спинався на ноги. Також учений зазначає, що критичне ставлення до позитивізму ґрунтується на тому, що він не зазначає провідної ідеї, яку обстоює доктрина природного права, стверджуючи, що закони, позбавлені внутрішньої моральності, - це не справедливі закони, а тому вони не можуть вимагати лояльності до себе; якщо ж законам бракує внутрішньої моральності - то вони не заслуговують на те, щоб називатись правом [8, с. 204, 205]. 
Далі, у більш пізніх лекціях, вчений наголошує, що правдива демократія, людські права та правовладдя як основа європейського порядку - це тріада цінностей, які перебувають у нерозривному зв'язку між собою [8, с. 371].

Цікавим $€$ й те, що С.П. Головатий цілком слушно визначає, звертаючи увагу якраз на функціональний аспект людських прав. Зокрема, функціональний аспект внутрішнього виміру людських прав охоплює певні вимоги. Їх вчений виділяє чотири: (а) якщо є потреба в застереженнях щодо прав (їх обмеженні), то при цьому слід поважати принципи оптимізації людських прав (дотримуватись принципу найменш можливого обмеження); (б) втручання в людські права повинні бути засновані на приписах права, спиратися на легітимну підставу, бути такими, що $€$ неодмінними в демократичному суспільстві, бути єдиним цілком відповідним (адекватним) засобом досягнення означеної легітимної підстави (відповідати принципам пропорційності); (в) стрижень (ядро) людських прав - тобто сама їх природа, сама їхня сутність - не повинні зазнавати ураження; (2) дієвий (ефективний) судовий захист людських прав є обов'язковим, що не припускає жодних винятків [8, с. 415-416]. Із такими твердженнями та підходами слід повністю погодитись. Оскільки вони дають можливість забезпечити гарантії панування права людини в ії соціокультурному бутті, надають можливість закріпити гідність кожної людини тощо. На нашу думку, головна ідея чітко відслідковується у збережені правопорядку, збереженні цінностей людини, які б акумулювали здорове суспільство загалом. Діалектика й логіка такої основи одна - через правовий закон та демократію закласти фундамент для соціальної, демократичної та правової держави, що й закріплено в ст.1 Конституції України.

У соціально-правовому аспекті якраз постає за важливе розглянути різні світоглядні погляди на проблему соціального права через його дисфункцію.

Ведучи мову про агресію та природу людини, П.І. Гнатенко справедливо звертає увагу на дослідження Т.Г. Румянцевої («Агрессия: проблемы и поиски в западной философии и науке», 1991р.) стосовно того, що серед найбільш суттєвих результатів слід виділити зв'язок між агресією та негативними факторами оточуючого середовища [10, с. 66]. «На думку Д. Mopica («Голая обезьяна», 2001 р.), - пише П.І. Гнатенко, - правдива ціль міжвидової агресії на біологічному рівні - придушення, а не ліквідація суперника. До кінцевої стадії - знищення життя на Землі - справа не доходить: суперник або спасається втечею, або здається. Причому в обох випадках зіткнення суперників зупиняється, спір вирішений. Якщо ж напад здійснюється з такої відстані, що сигнали про визнання своєї поразки не можуть бути прочитані пере- можцем, то розпочинається жорстока агресія» [10, c. 155].

У сучасній фрілософії в контексті ідеї «масового суспільства» як центрального наративу постсучасної фрілософії підтримується позиція стосовно того, що сучасне масове суспільство «...є продуктом розвитку індустріальної цивілізації під її гаслом безперервного виробництва споживчих вартостей та неминучим наслідком постіндустріальної «гіперреальності економіки», яка набуває глобального характеру та виходить далеко за межі матеріального виробництва, продукуючи абсолютно все - від електронних гаджетів та ембріонів до «виробництва» віртуальних стосунків та почуттів» [25, с. 198].

3 погляду фрілософії права у такому процесі не важко помітити не тільки соціальний аспект, але й аспект постмодерну права. Це дозволяє прогнозувати «модель» права та соціальні зв'язки його структури, які, однак, не визначають позитивний горизонт для людини, суспільства загалом.

Варто зазначити, що постмодернізм права поглиблюється. Під постмодерном права у вихідних його постулатах розуміються: розуміння мови як такої, що конститує реальність; відмова розуму в універсальності, всеосяжність та спроможність пізнати свою структуру та межі; акцент на відсутності однозначності та абсолютності смислу мовних висловлювань; перевага ірраціонального та несвідомого у поведінці людей; ірраціоналізація бюрократії як наслідок раціоналізації політики; обмеження свободи людини в умовах демократії [6, с. 594].

Не було б зайвим визначити ключові ідеї фрілософії трудового права, у яких також відстежуються прояв постмодерну соціального права і до того ж у різних сферах та проявах.

Так, професорка Т.А. Занфірова у посібнику із фрілософії трудового права зазначає, що «...критичне ставлення до трудового права, на якому вибудовується будь-яка філософія трудового права (бо всяка фрілософрія трудового права це критика й критицизм стосовно такого позитивного трудового права, яке ототожнюється із трудовим законодавством), означає допущення того, що той, хто судить за джерелом формального права (наприклад, звільняє працівника за незначне порушення трудової дисципліни), може бути неправим по суті, оскільки базує свої судження на недосконалому законі. <...> Ідея й ідеали справедливості, як і всі інші ціннісні універсалії, $€$ надісторичними <..> Прагнення до справедливості завжди було для людства одним із головних орієнтирів соціального прогресу. У справедливості органічно поєднані минуле і сучасність...» [11, с. 57].

Вчена, погоджуючись із М. Михальченком, пропонує визначати чотири основні підходи до проблеми соціальної справедливості з погляду розподілу благ: (а) «егалітарний» підхід - усі 
члени суспільства отримують однакові блага, тобто має місце нібито їх рівний розподіл між індивідами; (б) «утилітарний» або «цілераціональний» підхід, за яким ідея полягає у тому, аби блага розподілялися таким чином, аби максимально збільшити користь членів суспільства; (в) «роулсіанський» або «ліберально-дистрибутивний» підхід, за якого засобами державного регулювання (зазвичай за допомогою податкової системи) максимізується прибуток і продуктивність найбільш забезпечених осіб у суспільстві; (2) «ринковий» або «стихійно-ліберальний», «манчестерський» підхід laissez faire («нехай буде, як буде»), який закріплює ідею стосовно того, що справедливість встановлюється ринковою конкуренцією, а тому не вимагає ніякого врегулювання [11, с. 57-61]. Зрештою, вчена відстежує те, що справедливість (соціальна справедливість - Я.М.) закономірно дістає перехід до рівності. Адже рівність - це цінність, що пов'язана з нормативним правом [11, с. 68-69].

Не було б зайвим зазначити, що сьогодні трудове право у системі соціального права розвивається винятково в «дусі» соціального нормативу. Зокрема, у трудовому праві укорінилося поняття «соціальний діалог у сфері праці». Під ним розуміють процес визначення та зближення позицій, досягнення спільних домовленостей та прийняття узгоджених рішень сторонами соціального діалогу. Також соціальний діалог у сфрері праці визначається як один із основних принципів правового регулювання відносин; або ж як система колективних трудових відносин; та навіть як інститут колективного трудового права $[7$, с. 626]. Очевидним $\epsilon$ те, що законодавство про соціальний діалог відображає певну ідеологію, відображається у текстових документах. Зокрема, воно базується на Конституції України, ряду міжнародних договорів, які ратифіковані Україною, а також на КЗпП, Законах України: «Про соціальний діалог в Україні», «Про колективні договори і угоди», «Про оплату праці», «Про порядок вирішення колективних трудових спорів (конфоліктів)», «Про профресійні спілки, їх права та гарантії діяльності», «Про організації роботодавців, їх об'єднання, права і гарантії їх діяльності», а також ряд інших підзаконних нормативно-правових актів [7, с. 626-627]. Зрештою, цілком природнім та передбачуваним $€$ те, що під соціальним діалогом у сфері праці розуміють керівну ідею, основоположну засаду, що виражає сутність, основні властивості й загальну спрямованість норм інститутів колективів трудового права, а також окремих інститутів індивідуального трудового права (курсив власний - Я.М.) [7, с. 628]. Натомість соціальний діалог у сфрері трудового права не $є$ повномірним поняттям, яке б відповідало в узагальненому вигляді ідеології соціального права. Це пов'язано із тим, що воно сфрокусоване винятково на забезпеченні та гарантуванні реалізації трудових прав, попри те, що $€$ «соціальним». Соціальне ж право - це широке поняття. Принаймні воно враховує значну частину житлових, сімейних, цивільних правовідносин, кримінально-виконавчих відносин, адміністративних відносин. Ось, наприклад, соціальний діалог у сфері соціального права тільки з огляду на зміст Закону України «Про соціальні послуги» від 17 січня 2019 року № 2671-VIII (надалі - Закон від 17 січня 2019 року № 2671-VIII) дає можливість значно розширити ідеологію соціального права. Адже у ньому йдеться про фундаментальні категорії, інститути та режими соціального права, а саме про вразливі групи населення, забезпечення найкращих інтересів отримувачів соціальних послуг, малозабезпечених осіб тощо [23]. Цей Закон від 17 січня 2019 року № 2671-VIII визначає й чинники, що можуть зумовити складні життєві обставини, і таким чином вказує на додаткові важливі аргументи щодо розширення ідеології соціального права через текстовий символ закону як виразу соціальної дійсності права. Зокрема, серед таких: похилий вік; часткова або повна втрата рухової активності, пам'яті; невиліковні хвороби, хвороби, що потребують тривалого лікування; психічні та поведінкові розлади, у тому числі внаслідок вживання психоактивних речовин; інвалідність; бездомність; безробіття; малозабезпеченість особи; поведінкові розлади у дітей через розлучення батьків; ухилення батьками або особами, які їх замінюють, від виконання своїх обов'язків із виховання дитини; втрата соціальних зв'язків, у тому числі під час перебування в місцях позбавлення волі; жорстоке поводження з дитиною; насильство за ознакою статі; домашнє насильство; потрапляння в ситуацію торгівлі людьми; шкода, завдана пожежею, стихійним лихом, катастрофою, бойовими діями, терористичним актом, збройним конорліктом, тимчасовою окупацією [23]. Отже, хоча наведений перелік $є$ далеко не повним та досконалим, він акумулює необхідність соціального діалогу, який повинен відбутися задля більш повного забезпечення ідеології соціального права, як і усунення конфрліктів у суспільстві.

У такому ключі постановки проблеми доречно звернути увагу на ідеологію так званого «безпекового закону» на предмет того, чи регулює він основні соціальні проблеми на рівні феномену безпеки? Наприклад, відповідно до ст. 1 Закону України «Про національну безпеку» від 21 червня 2018 р. № 2469-VIII (надалі - Закон від 21 червня 2018 р. № 2469-VIII), визначено такі основні безпекові поняття соціального характеру: «громадська безпека і порядок», «демократичний цивільний контроль», «Стратегія громадської безпеки та цивільного захисту України» тощо [24]. Мета цього Закону від 21 червня 2018 р. № 2469-VIII фокусується як основа «...для інтеграції політики та процедур органів державної влади, інших державних органів, функції яких стосуються сфрер національної без- 
пеки, забезпечуючи у такий спосіб демократичний цивільний контроль над органами та фрормуваннями сектору безпеки...». Як бачимо, дійсно, Закон від 21 червня 2018 р. № 2469-VIII визначає певні критерії врегулювання соціальної політики та соціальної безпеки, чим значно розширює ідеологію самої конструкції соціального права. Відповідно, цей аспект повинен бути визнаний в доктрині права як складник прояву ідеології соціального права в частині функціонування феномену соціальної безпеки.

Доволі влучно зазначає щодо цього Ганс Кельзен (найінноваційніший представник теорії позитивізму права), який відмічає, що «...коли уявити пересічну картину, котра $€$ реальним станом державності, що визначається як демократія, та зіставити її із демократичною ідеологією свободи, то дивуєшся, як така надзвичайна напруга між ідеологією і дійсністю може взагалі триматися так довго. На перший погляд, це ніби функція демократичної ідеології: ілюзія збереження свободи, яку годі й врятовувати в суспільній дійсності...» [15, с. 111]. Водночас Г. Кельзен зазначає, що демократії, що засновані на засаді більшості та з марксистського боку протиставляються формальній та буржуазній, - це і є демократія соціальна, пролетарська, під чим розуміється такий суспільний лад, що гарантує громадянам не лише формально вільну участь у виробленні суспільства, а й у певному розумінні рівну кількість економічних благ. Це протиставлення, на думку вченого, слід відхилити. Адже ідея нерівності, а саме свободи, насамперед визначає демократичний світогляд. Тому позаяк усі мають бути вільними, але й одночасно бути причетними до вироблення державної волі, а отже, рівною мірою причетними [15, с. 125].

Отже, у разі небезпеки (в тому числі і в контексті екологічному, соціальному), важливими $є$ фактори належної комунікації, які пізнаються через знакову-сигнальну систему. Право сприймається як знакова система, $€$ соціальним феноменом та відображається в комунікативному аспекті його дії. Водночас комунікація здатна долати агресію, проте агресія може мати природне походження, маючи основу неналежного природного середовища. Водночас стає очевидним, що конфлікт у праві $є$ стійким соціальним феноменом.

На думку C.В. Бобровник, антропо-комунікативне право пізнання конфллікту і компромісу охоплює найкращі аспекти природно-правової та соціально-психологічної концепцій права і розкриває індивідуальний та соціальний аспекти правового буття людини у біполярному соціумі [5, с. 35$]$.

О.М. Костенко не без підстав зазначає, що без належної соціальної культури людський фактор проявлятиметься у вигляді зловживань законодавством [16, с. 8].

А.М. Кучук доводить, що соціокультурна зумовленість права є фрактором правового полі- центризму, чим і актуалізує необхідність саме соціокультурного підходу до розуміння права, обмеженості правопізнання у межах наукового підходу з його надмірною зосередженістю на раціональному складнику, адже людині властива амбівалентність (подвійний сенс у сприйнятті одного і того ж об'єкту, явища, ідеї (розщеплення), предмету - «добро» і «зло», «любов» чи «ненависть» тощо* - Я.М.) [17, с. 191]. Очевидно, що «амбівалентність» у праві цілком $€$ логічним феноменом, оскільки закладає сенси міждисциплінарні у розуміння буття права, виступає основоположною ідеєю у взаємозв'язку однієї галузі із іншою.

Як відмічає М.І. Іншин та Д.Г. Севрюков, дискусія про природу соціальних прав - етичну чи юридичну - не стосується природної об'єктивності. Це, на їх думку, суперечка, що породжена та існує винятково в межах ідеологічних дискурсів. Наприклад, вчені доводять, що будь-яка ідеологічна мова вичерпно описує, позначає, а фактично конструює соціальну реальність. Соціальний світ $є$ насамперед світом знаків, а поза ними ніякої реальності для людини не існує. Адже право як соціальне явище існує, коли воно набуває знакову форму. Водночас право $\epsilon$ конвенційним витвором професійного середовища у формі особливих знаків та символів. Відтак право, на думку М.І. Іншина та М.Г. Севрюкова, поряд з іншими знаковими системами формує соціокультурну реальність, у якій відбуваються суспільні комунікації. Мова як надбання політики виступає засобом утворенням символічних уявлень про статусні можливості та обов'язки індивідів, їх місце у політико-правовій системі, призначення, функції держави [13, с. 13-14].

Реалізація соціального права без комунікації неможлива. В ідеї соціального права якраз і закладена суть комунікативного аспекту. Рівень соціального права $є$ суспільним, зумовленим за своєю природою безпосередньою комунікацією між державою та людиною, окремою соціальною групою, суспільством.

Економічні та соціальні права у своїй основі $€$ забезпечувальними правами на належні умови життя, які до того ж потребують фінансових асигнувань, певного рівня забезпечення - матеріальної підтримки, нематеріальної підтримки з боку основного гаранта дотримання прав. Адже сенс (правове буття) людини у правовому просторі зумовлений певними об'єктивними та суб'єктивними чинниками (урбанізованим суспільством, втратою працездатності, складними життєвими обставинами, постійною зміною прожиткового мінімуму, розвитком інформаційних технологій, зміною умов доступу до освіти, доступу до правосуддя тощо). Отже, аксіоматично виходить, що держава повинна постійно комунікувати, моніторити та визначати належний діалог для збалансування соціальних умов проживання 
у ній. 3 іншого боку, громадянин, окремі соціальні групи, власне як і суспільство загалом, повинно віднаходити між собою належний соціальний діалог, який повинен слідувати факторам розвитку правової культури, обізнаності у праві.

Комунікація повинна відбуватись на рівні законодавчого врегулювання соціальних прав та механізмів їх забезпечення та регулювання завдяки доведенню їх до належного, життєво та суспільно важливого рівня, враховуючи реалії сьогодення.

О. Балинська, досліджуючи семіотику права, доходить висновку, що «....право - це особливий тип мовлення та комунікації зі специфічними характеристиками, які залежать від того, хто виступає адресантом та адресатом...» [4, с. 373]. Також вчена солідарна із деякими дослідниками стосовно того, що «...суспільство також можна вважати джерелом виникнення сигналів у праві...» [27, с. 12; 4, с. 26]. Варто зазначити і те, що в результаті проведеного дослідження вчена доходить висновків стосовно того, що «...право саме є сигналом і сприймається завдяки сигнальним системам людини, які соціально зумовлені й функціонують у середовищі міжсуб'єктної соціальної (у тому числі правової) комунікації. Сигнальна дія права пов'язана з наявністю у правосвідомості людини певних динамічних стереотипів, а також із її здатністю до абстрагування. При цьому основним сигналом права $є$ слово, а мова права виступає вербальною абстракцією правової дійсності...» [4, c. 28].

O.В. Мінченко, досліджуючи роль семіотики у процесах утворення та реалізації права, зазначає, що оскільки правові приписи фрормуються не через будь-які правові засоби, а лише через такі, які використовуються для утворення перформативних висловлювань, то, відповідно, мова права завжди відрізняється від літературної та народної мови [19, с. 35].

На думку О.М. Балинської, право у семіотичному ключі вже постає як особлива призма, через яку заломлюється промінь (інформаційний потік) відображення правової дійсності й одночасно фокусується у точці сприйняття конкретним соціальним суб'єктом і розпорошується на необмежену кількість таких правосприймачів. Герменевтичний підхід до розуміння інформації у праві, на думку вченої, забезпечує процес своєрідної інформаційної взаємодії в межах правової дійсності, правової комунікації [4, с. 156]. Дослідниця не без підстав відмічає, що функціональне призначення правового моделювання полягає в тому, що воно допомагає: зрозуміти, як облаштований конкретний об'єкт (яка структура правової системи, якими властивостями наділені норми права, який механізм правового регулювання тощо); навчитися управляти об'єктом чи процесом та визначати найефективніші способи управління при певних завданнях і кри- теріях (оптимізація процесу правового регулювання); прогнозувати прямі й побічні наслідки реалізації заданих способів і фрорм впливу на об'єкт (внесення змін чи доповнень в одну норму права може суттєво скоригувати систему права загалом) [4, с. 172].

Д.П. Співак вбачає семіотику в урбаністиці, яка також не позбавлена соціальної функції. Зокрема, дослідник зазначає, що сучасні міста потребують символьної політики, яка допомагає зберігати семіотичну цілісність (ідентичність) міста, а також підключати його символи до державної символіки загалом для збереження національно-державної ідентичності та цілісності держави. Вивчення міста як знакової системи через аналіз політичної компоненти архітектури (особливо представницької), пам'ятників (особливо «пам'ятників війни»), політичних наслідків зміни урбаністичного ландшафту, політичних механізмів гуманізації відчужених міських просторів тощо $є$ перспективними напрямами подальших наукових розвідок [26, с. 37]. Якраз у ключі урбаністики відслідковується зв'язок соціального права із муніципальними, соціальними та екологічними правами. Так, з позиції Л.В. Голяк та В.П. Садовнік «...муніципальні права і свободи складають важливий елемент змісту всієї системи місцевого самоврядування. Муніципальні права - це права, які забезпечують реальні можливості кожного члена місцевої громади в участі у вирішенні всіх питань місцевого значення, в управлінні та користуванні муніципальною власністю, безпосередньому здійсненні особистої свободи на основі безпеки й недоторканості особистості [9, с. 33]. Як бачимо, муніципальні права з'єднуються із феноменом безпеки.

За таких обставин слід погодитись із тим, що в соціально-правовому сенсі семіотику слід розглядати як особливу концепцію, яка надає можливість з'ясувати насамперед базисні надбудови системи правового регулювання в соціальному праві, а також як сферу правової політики соціального права на предмет придатності, зрозумілості та доступності норм соціального права [18, с. 95], а по суті - політики - яка визначає функціональність ідеології самого соціального права, його соціальної структури, соціальної безпеки.

Отже, стосовно тез, які стосуються соціально-екологічного змісту проблеми, стає очевидно, що ідеологія соціального права націлена на комплексне забезпечення безпеки за допомогою комунікативного та семіотичного виразу права. Але одночасно ця проблема дає нам можливість пізнати неповноту умов забезпечення соціально-екологічного добробуту через знакову систему - через мовний його текстуальний вираз (форму) - в законах, у знаках тощо. Оскільки функціональна спрямованість соціально-правової ідеології набуває додаткових, особливих умов, функціонально-взаємозалежні 
чинники визначають принципово новий характер забезпечення безпеки. А функція соціального права, очевидно, вже дістає ширшої спрямованості на забезпечення врегулювання правовідносин у суспільстві.

Висновки. Отже постає очевидним, що соціальне право як феномен характеризується тим, що будь-яка його функціональна спрямованість не може бути пізнана без чітких напрямів його дії, які формуються, спираючись на конкретну ідею, продуковану джерелом соціального права, його цілісною знаковою системою. Ідея права - ніби «проміння світла», його політики, а, власне природи соціального права. Природа соціального права має витоки із джерела, яким є сама людина. «Функція» та «ідея», як і сама «ідеологія», - нерозривні, парні соціальні феномени. Якщо функція відповідає на питання «для чого?» (в контексті правового регулювання - Я.М.), то й ідеологія, відповідно, зобов'язана відобразити процес функціональної його спрямованості, що сфокусована на виконанні певного завдання, отриманні соціально-значимого результату. В праві результат - це не стільки воля законодавця, скільки фракт соціальної спрямованості забезпечення та охорони прав, свобод та інтересів. Воля законодавця - це лише проміжний спосіб позитивної легітимації соціальної необхідності між людиною та людиною, в суспільних відносинах в комунікаційному аспекті. Наскільки буде вдало та оперативно витриманий комунікаційний аспект ідеології права, настільки й буде ефективно досягнуто у часовому еквіваленті результату визначеності в соціальному праві, настільки й буде подолана розбіжність між поглядами на те чи інше соціальне правило поведінки та дисфункція соціального права в його образах у суспільстві.

Безпека текстової ідеології соціального права $€$ комплексним, багатогранним та міждисциплінарним феноменом права. Вона засновується на соціальному діалозі у сфері соціального права. Функціональна спрямованість текстової ідеології соціального права визначається унікальною метою - забезпечити швидкий доступ до соціальних прав, однозначне розуміння юридичних текстів соціального законодавства та юридичної практики в суспільстві. Така функціональна спрямованість забезпечується семіотичними ідеями доктрини соціального права. Соціальна семіотика права у такому ключі постає і як спосіб забезпечення ефективного соціального моделювання та технологій соціальних норм в життя людини у суспільстві, і як спосіб ефективного забезпечення реалізації соціальних прав, впливу права на людину у соціально-неоднорідному суспільстві, формування її правової культури у «найкоротший шлях».

\section{Список використаних джерел:}

1. Актуальні грані загальнотеоретичної юриспруденції: монографія/ [Ю.М. Оборотов, В.В. Завальнюк, В.В. Дудченко та ін.] ; за ред. Ю.М. Оборотова. Одеса : Фенікс, 2012. 492 с.

2. Амбівалентність - значення слова.... / Вільна енциклопедія «Вікіпедія». URL: https://uk.wikipedia.org/wiki /\%D0\%90\%D0\%BC\%D0\%B1\%D1\%96\%D0\%B2\%D0\%B0\%D0\%BB\%D0\%B5\%D0\%BD $\%$ D $\% 1 \% 82 \%$ D0 $\%$ BD $\%$ D $1 \%$ $96 \% \mathrm{D} 1 \% 81 \% \mathrm{D} 1 \% 82 \% \mathrm{D} 1 \% 8 \mathrm{C}$.

3. Барабаш Ю. Беззахисні права чи необгрунтовані сподівання?. Газета «Голос України» від 5 травня 2016 р. URL: http://www.golos.com.ua/article/268300.

4. Балинська О.М. Семіотика права : монографія / О.М. Балинська. Львів : ЛьвДУВС, 2013. 416 с.

5. Бобровник С.В. Компроміс і конфлікт у праві: антрополого-комунікативний підхід до аналізу : монографія. Київ : Вид-во» Юридична думка», 2011. 384 с.

6. Велика українська юридична енциклопедія: у 20 т. Харків : Право, 2016. Т. 2 Філософія права / редкол. : C.I. Максимов (голова) та ін.; Нац. акад. прав. наук України; Ін-т держави і права імені В.М. Корецького НАН України; Нац.юрид. ун-т імені Ярослава Мудрого. 2017. 1128 с.

7. Велика українська юридична енциклопедія: у 20 т. Харків : Право, 2016. Т. 11 : Трудове право / редкол.: C.М. Прилипко (голова), М.І. Іншин (заст.голови), О.Я. Ярошенко та інші; Нац. акад. прав. наук України; Ін- держави і права ім. В.М. Корецького НАН України; Нац. юрид. ун-т ім. Ярослава Мудрого. 2018. 776 с.

8. Головатий С. Про людські права. Лекції. Київ : ДУХ І ЛІТЕРА, 2016. 760 с.

9. Голяк Л.В., Садовнік В.П. Особливості муніципального рівня забезпечення та захисту прав і свобод людини і громадянина. «Young Scientist». № 12.1 (76.1). December, 2019. C. 33-37.

10. Гнатенко П.И. Психология агрессивности человека. Киев : Наукова думка. 2017. 172 с.

11. Занфірова Т.А. Філософія трудового права : навчально-методичний посібник для студентів юридичних факультетів і відділень / Т.А. Занфірова. Харків : Константа, 2018. 515 с.

12. Іншин M.I. Щербина В.І. Ідеологічні основи сучасного трудового права України : монографія. Харків : Діса плюс, 2016. 328 с.

13. Іншин М.І., Севрюков Д.Г. Соціальне громадянство: історія та сучасність : монографія. Київ : Видавництво Людмила, 2020. 208 с.

14. Карантин у Києві: якими будуть обмежувальні заходи. Укрінформ. URL: https://www.ukrinform.ua/ rubric-kyiv/2894080-karantin-u-kievi-akimi-budut-obmezuvalni-zahodi.html.

15. Кельзен Г. Про сутність і цінність демократії. Вступне слово Ю.Л. Бошицький $\backslash$ переклад 3 нім. на укр. О. Макровольський. ВНТЛ-КЛасика. 2013. 139 с. 
16. Косенко О.М. Феномен права у світлі соціального натуралізму. Часопис Київського університету права. № 2, 2005. C. 3-12.

17. Кучук А.М. Основи теорії правового поліцентризму : монографія. Дніпро : Дніпроп. держ. Ун-т внутр. Справ ; Ліра ЛТД, 2017. 312 с.

18. Мельник Я.Я. Концепція семіотики у соціальному праві: проблеми доктринальної політики. Актуальні проблеми права: теорія і практика. №1 (39), 2020. С. 91-97. URL: http://ns.snu.edu.ua/index.php/actual-law/article/ view/103/101.

19. Мінченко О.В. Роль семіотики в процесах утворення та реалізації права. Актуальні проблеми вітчизняної юриспруденції. № 3, 2018. С. 32-35.

20. Оборотов Ю.М., Крестовська Н.М., Крижанівський А.Ф., Матвєєва Л.Г. Теорія держави і права. Державний іспит. Харків : Одіссей, 2010. 256 с.

21. Оніщенко Н.М., Пархоменко Н.М. Соціальний вимір правової системи: реалії та перспективи : монографія / Відп. ред. Ю.С. Шемшученко. Київ : Видавництво «Юридична думка». 2011. 176 с.

22. Познер Ричард А. Економічний аналіз права. Переклад з англійської Сергія Савченка : Акта, 2003. 862c.

23. Про соціальні послуги: Закон України від 17 січня 2019 року № 2671-VIII. Верховна Рада України. URL: https://zakon.rada.gov.ua/laws/show/2671-19\#n482.

24. Про національну безпеку України. Закон від 21 червня 2018р. № 2469-VIII. Верховна Рада України. URL: https://zakon.rada.gov.ua/laws/show/2469-19\#Text.

25. Сайтарли I.А., Іщенко О.М., Приятельчук А.О. Нариси з сучасної філософії : навчальний посібник для магістрів та здобувачів ступеня доктора філософії / І.А. Сайтарли, О.М. Іщенко, А.О. Приятельчук (за ред. академіка НАН України Л.В. Губерського). Київ : «ВАДЕКС», 2016. 370 с.

26. Співак Д.П. Семіотика як методологія дослідження політичної урбаністики. Науковий часопис НПУ імені М. П. Драгоманова. Випуск 20, 2016. С. 33-38.

27. Токарська А.С. Правова комунікація в контексті посткласичного право розуміння : автореф. дис. на здобуття наук. ступеня доктора юрид. наук : спец. 12.00.12 / А.С. Токарська. Київ, 2008. 38 с.

28. Філософський енциклопедичний словник / В.І. Шинкарук та ін. ; НАНУ, Ін-т філософії ім. Г.С. Сковороди. Київ : Абрис, 2002. 742с.

29. Фюрст М., Тринкс Ю. Філософія / пер. з нім. Вахтанга Кебуладзе. Київ : ДУХ І ЛІТЕРА, Інститут релігійних наук св. Томи Аквинського, 2018. 544 с.

30. Юридична енциклопедія: В 6 т. / Редкол. : Ю.С. Шемшученко (голова редкол.) та ін. Київ : «Укр .енциклоп.», 1998. Т. 2 : Д - Й. 1999. 744 с.

31. Юридична енциклопедія: В 6 т. / Редкол. : Ю.С. Шемшученко (голова редкол.) та ін. Київ : «Укр.енцикл.», 1998. Т. 5: П- С. 2003. 736 с. 
УДК 347.78

DOI https://doi.org/10.37687/2413-6433.2020-1.9

\author{
Новицька Н.Б., \\ доктор юридичних наук, старший науковий співробітник, \\ доцент кафедри цивільного права та процесу \\ Університету державної фіскальної служби України \\ ORCID: 0000-0003-4753-7625 \\ Таранюк T.O., \\ здобувач Навчально-наукового інституту права \\ Університету державної фіскальної служби України \\ ORCID: 0000-0003-2926-087X
}

\title{
ОСОБЛИВОСТІ ПРАВОВОГО РЕГУЛЮВАННЯ \\ ПРАВА ІНТЕЛЕКТУАЛЬНОЇ ВЛАСНОСТІ НА ТВІР, СТВОРЕНИЙ У ПРОЦЕСІ ВИКОНАННЯ ТРУДОВОГО ДОГОВОРУ
}

\section{PECULIARITIES OF LEGAL REGULATION \\ OF INTELLECTUAL PROPERTY RIGHT TO A WORK CREATED IN THE PROCESS OF EXECUTION OF AN EMPLOYMENT CONTRACT}

\begin{abstract}
У статті досліджуються особливості правового регулювання права інтелектуальної власності на твір, створений у процесі виконання трудового договору, в умовах соціально-економічного та політичного розвитку держави, на тлі науково-технічного прогресу та розширення можливостей інформаційного простору, коли творчий та науковий потенціал працівників підприємств, установ та організацій набуває особливого значення, а правовідносини щодо розподілу прав інтелектуальної власності між працівником та роботодавцем $є$ досить поширеними. Також проаналізовано особливості правового статусу об'єктів права інтелектуальної власності, створених у процесі виконання трудового договору. Розглянуто поняття особистих немайнових та майнових прав автора службового твору. Крім того, здійснено аналіз нормативно-правових актів з питань, що стосуються розподілу прав інтелектуальної власності на службові твори між працівником та роботодавцем, а також проведено порівняння загального та спеціального законодавства, на основі чого досліджено правові колізії щодо цього питання, які негативно впливають на правове регулювання правовідносин у цій сфері та сприяють неоднаковому застосуванню законодавства під час врегулювання цього виду правовідносин та вирішення спорів, що виникають внаслідок цього. 3 огляду на судову практику здійснено аналіз діяльності суддів з розгляду справ за позовами про порушення прав інтелектуальної власності на твори, створені у процесі виконання трудового договору, а також визначено їх правову позицію, згідно з якою майнові права на об'єкт авторського права і (або) суміжних прав, створений у зв'язку з виконанням трудового договору, належать працівникові, який створив цей об'єкт, та юридичній або фізичній особі, де або в якої він працює, спільно, якщо інше не встановлено договором. Досліджено питання щодо необхідності сплати авторської винагороди та доцільності вважати ії окремою виплатою за використання службового твору чи, можливо, необхідності включити ії в заробітну плату, передбачену трудовим договором. Проаналізовано значення трудового договору та цивільно-правових угод як одного із способів правового регулювання розподілу прав на об'єкт права інтелектуальної власності, створений у процесі виконання такого договору. Розроблено пропозиції, спрямовані на удосконалення регулювання відносин між працівником і роботодавцем щодо використання об'єктів права інтелектуальної власності, створених у процесі виконання трудового договору.
\end{abstract}

Ключові слова: право інтелектуальної власності, авторське право, службовий твір, трудовий договір, прачівник, роботодавець, авторська винагорода.

The article examines the peculiarities of legal regulation of intellectual property rights in a work created in execution of an employment contract, in terms of socio-economic and political development of the state, against scientific progress and empowerment of the information space, when the creative and scientific potential of employees of enterprises, institutions and organizations is of particular importance, and the relationship about the distribution of intellectual property rights between the employee and the employer are quite common. Also analyzed are the features of the legal status of intellectual property rights created in the process of execution of the employment contract. The concept of personal non-property and property rights of the author of the official work is considered. In addition, the analysis of normative-legal acts on issues concerning allocation of intellectual property rights on the service-related work between the employee and the employer, as well as a comparison of General and special legislation, which investigated the legal conflict on this issue, which adversely affect the legal regulation of legal relations in this field and contribute to the unequal application of the law in resolving this type of legal relationships and disputes arising out of this. On the basis 
of judicial practice, the analysis of the activities of judges on consideration of cases involving claims of violation of intellectual property rights in works created in execution of an employment contract, and defined their legal position in the following terms: property rights on objects of copyright and (or) related rights created in connection with the performance of the employment contract, belong to the employee who created this object, and legal or natural person where or in which he is working, together, unless otherwise provided by contract. The question of necessity of payment of author's remuneration and expediency to consider it as separate payment for use of office work, perhaps need to include it in the salary provided by the employment contract is investigated. Analyzed the value of the employment contract and civil transactions, as one of methods of legal regulation of allocation of rights to intellectual property created during the execution of such contract. The proposals aimed at improving the regulation of relations between the employee and the employer on the use of intellectual property rights created in the course of the employment contract.

Key words: intellectual property law, copyright, official work, employment contract, employee, employer, copyright remuneration.

Постановка проблеми. Нині, на сучасному етапі соціально-економічного та політичного розвитку держави, на тлі науково-технічного прогресу та розширення можливостей інформаційного простору важливого значення для підтримання конкурентоспроможності на ринку економіки набуває не забезпеченість установи, організації чи підприємства найновітнішими розробками науки й техніки, а творчий та науковий потенціал їх працівників. Тому в умовах зростання ролі творчої діяльності та винахідливості працівника виникає питання, що стосується саме розподілу прав (як майнових, так і особистих немайнових) на об'єкти інтелектуальної власності, а також необхідного правового регулювання цих правовідносин між працівником та його роботодавцем.

Законодавець неодноразово намагався здійснити правове регулювання цього виду правовідносин, оскільки більшість об'єктів права інтелектуальної власності створюється саме у процесі виконання працівниками своїх обов'язків, що передбачені трудовим договором. Проте, в чинному законодавстві міститься ряд суперечностей, що стосуються розподілу прав на об'єкти права інтелектуальної власності, що створені в процесі виконання трудового договору, між працівником та роботодавцем.

Аналіз останніх досліджень і публікацій. Питання правового регулювання права інтелектуальної власності на твір, створений у процесі виконання трудового договору, досліджувалися в працях Р.О. Денисова, М.І. Іншина, С.М. Клейменової, А. Кодинеця, Ю.С. Єпіфанової, Ю.О. Сошникова, І. Томарова, О.О. Штефан та інших.

Метою статті $\epsilon$ дослідження цивільно-правових елементів правового регулювання відносин у сфрері розподілу прав інтелектуальної власності на твори, створені у процесі виконання трудового договору, а також аналіз чинного законодавства та судової практики у цій сфері, розробка пропозицій, спрямованих на удосконалення регулювання відносин між працівником і роботодавцем щодо використання об'єктів права інтелектуальної власності, створених у процесі виконання трудового договору.
Виклад основного матеріалу. Основними нормативно-правовими актами, що регулюють це питання, є Цивільний кодекс України (далі ЦК України) [1] від 16.01.2003 та Закон України «Про авторське право і суміжні права» [2] від 23.12.1993 року. Саме в них містяться правові колізії, які сприяють неоднаковому застосуванню законодавства під час врегулювання цього виду правовідносин та вирішення спорів, що виникають внаслідок цього. Зокрема, посилаючись на Закон України «Про авторське право і суміжні права» [2], варто зазначити, що об'єкт права інтелектуальної власності, створений у процесі виконання трудового договору, набуває правового статусу службового твору.

Переходячи до питання розподілу авторських прав на об'єкт, створений у зв'язку з виконанням трудового договору (службовий твір), варто зазначити, що відповідно до ч. 1 ст. 429 ЦК України особисті немайнові права інтелектуальної власності на об'єкт, створений за замовленням, належать творцеві цього об'єкта [1]. Отже, ми можемо бачити, що особисті немайнові права, з огляду на свою природу (є невіддільними від особи автора), належать працівникові, який створив об'єкт інтелектуальної власності. Уч. 1 ст. 16 Закону України «Про авторське право і суміжні права» закріплені аналогічні положення, згідно з якими авторське особисте немайнове право на службовий твір належить його автору [2].

Таким чином, норми загального законодавства, закріплені в ЦК України та спеціального законодавства та в Законі України « Про авторські права і суміжні права», однозначно і чітко зазначають, що особисті немайнові права на службовий твір, такі як право на авторство, право на недоторканість твору, право на опублікування та інші, беззаперечно належать особі, що створила об'єкт інтелектуальної власності у зв'язку з виконанням трудового договору, тобто працівникові. Проте поряд з особистими немайновими правами на службовий твір виникають ще і майнові права, питання правового розподілу яких між працівником (автором) та роботодавцем викликають певні спірні питання.

Так, ЦК України у ч. 2 ст. 429 зазначає, що майнові права інтелектуальної власності на 
об'єкт, створений у зв'язку з виконанням трудового договору, належать працівникові, який створив цей об'єкт, та юридичній або фрізичній особі, де або у якої він працює, спільно, якщо інше не встановлено договором [2]. Здавалося б, законодавець логічно та справедливо вирішив питання розподілу майнових прав між працівником та роботодавцем, якби не одне але. Зокрема, Закон України «Про авторське право і суміжні права» по-іншому регулює це питання. Відповідно до ч. 2 ст. 16 даного Закону виключне майнове право на службовий твір належить роботодавцю, якщо інше не передбачено трудовим договором (контрактом) та (або) цивільно-правовим договором між автором і роботодавцем [2]. Тобто можемо бачити, що спеціальне законодавство повністю закріплює майнові права на службовий твір за роботодавцем, проте деталізує це положення тим, що автору твору за створення і подальше використання службового твору роботодавцем належить авторська винагорода, розмір та порядок виплати якої встановлюються трудовим договором або цивільно-правовим договором.

Ми можемо спостерігати правову колізію в законодавстві, яка може негативно впливати на розвиток правовідносин у сфері інтелектуальної власності, а також призвести до виникнення спорів між працівником та роботодавцем щодо цього. Тому одним із способів правового регулювання порядку розподілу прав на службовий твір $€$ зазначення у трудовому договорі, яким саме чином буде здійснено розподіл майнових прав, розміри та порядок виплати авторської винагороди.

Зокрема, говорячи про право на авторську винагороду, цікавим питанням $€$ порядок виплати авторської винагороди. Розглядаючи цю проблему, варто зауважити, що серед науковців, а також юристів-практиків немає згоди щодо того, чи доцільно авторську винагороду вважати окремою виплатою за використання службового твору, чи можливо необхідно включити її в заробітну плату, передбачену трудовим договором.

Так, Іларіон Томаров вважає, що необхідно відмовитися від поняття «авторської винагороди» та включити її в заробітну плату, оскільки: «...якщо слідувати формальній логіці, аби твір вважався службовим, обов'язок створювати твори має бути вказаний або в договорі, або в службовому завданні. Якщо ця умова дотримана, створення твору $€$ частиною трудових обов'язків, отже, за це працівник-автор отримує заробітну плату. Саме зарплата і $є$ єдиною формою винагороди за створення службових творів. Логіка додаткової винагороди за використання службового твору існує лише за умови, якщо авторські права належать автору, а роботодавець отримує ліцензію на використання твору способами, які зумовлені метою службо- вого завдання і в межах завдання. Якщо права за замовчуванням переходять до роботодавця, зникає підстава для виплати» [3].

Дійсно, чинне українське законодавство передбачає, що права на службовий твір належать роботодавцю згідно з Законом України «Про авторські права і суміжні права» або спільно - працівникові та роботодавцю - згідно з ЦК України. Здавалося б, у такому разі додаткова винагорода за використання такого твору позбавлена будь-якого сенсу, оскільки працівник, працюючи за трудовим договором, вже отримав все належне йому згідно з трудовим договором у вигляді заробітної плати.

Проте, на нашу думку, така позиція є несправедливою щодо працівника, який створив службовий твір, тому що роботодавець може використовувати створений працівником об'єкт права інтелектуальної власності за власним розсудом та бажанням безліч разів, отримувати від такого використання дохід, натомість працівник, згідно з позицією, зазначеною вище, має задовольнити свої майнові права на цей твір лише виплатою заробітної плати, яку б він отримав навіть і без створення об'єкта права інтелектуальної власності. Стає зрозумілим, що в такому разі автор службового твору не отримує належної йому винагороди за створений службовий твір. Наприклад, якщо розглядати рекламну продукцію як об'єкт права інтелектуальної власності, створений в процесі виконання трудового договору, то ми можемо лише уявити той прибуток, який отримає підприємство від використання такого твору, і розмір вигоди, не отриманої автором цього твору, якби йому належала за цей твір лише заробітна плата. Тому саме для задоволення майнових інтересів обох сторін законодавством і передбачена авторська винагорода за використання службового твору, створеного в процесі виконання трудового договору, і її включення та обмеження лише розміром заробітної плати є недоцільним.

Також у Постанові Пленуму Верховного Суду України «Про застосування судами норм законодавства у справах про захист авторського права і суміжних прав від 4 червня 2010 року зазначається, що за створення і використання службового твору автору належить авторська винагорода, розмір та порядок виплати якої встановлюються трудовим договором (контрактом) або цивільно-правовим договором між автором і роботодавцем. При цьому трудовим договором між ними може передбачатися умова щодо укладення цивільно-правового договору про створення об'єкта авторського права і (або) суміжних прав та обов'язок працівника щодо сповіщення про створення такого об'єкта [4].

Отже, з зазначеного вище можемо зробити висновок, що виплата працівникові заробітної плати не може замінити виплату йому автор- 
ської винагороди за створений твір у зв'язку з виконанням трудового договору.

Як зазначалося вище, укладання трудового договору або цивільно-правового договору $\epsilon$ одним із способів правового регулювання розподілу прав на об'єкт права інтелектуальної власності, створений у процесі виконання такого договору. Саме у договорі між працівником та роботодавцем можливо врегулювати всі питання, що стосуються процесу створення службового твору, розподілу прав, розміру, порядку та строків виплати авторської винагороди автору. Але насамперед необхідно звернути увагу на те, що сторони, уклавши трудовий договір або цивільно-правовий договір про розподіл прав, знаходять компроміс між своїми вимогами та вимогами опонента, досягають консенсусу, в результаті чого такі правовідносини будуються на довірі та повазі і, як наслідок, мінімізують можливість виникнення конфлліктів, які б потребували вирішення в судовому порядку.

Зазвичай для врегулювання питання розподілу прав на службові твори, створені в процесі виконання трудового договору, роботодавець укладає з працівником два договори: трудовий договір та цивільно-правовий договір про розподіл прав на об'єкти права інтелектуальної власності.

Зокрема, Ю.С. Єпіфранова, яка здійснює дослідження цього питання в сфері надання освітніх послуг, а саме врегулювання відносин щодо використання службових творів між науково-педагогічними працівниками та вищим навчальним закладом, вважає, що для вирішення питання щодо розподілу прав на службові твори необхідно укладати між роботодавцем та працівником: «...колективний договір, що встановлює основні гарантії у сфері творчої діяльності конкретного вищого навчального закладу, трудовий договір або контракт як індивідуальний підхід стосовно організації творчої діяльності та авторський договір, що закріплює строк його дії, спосіб використання твору, територію, на яку поширюється передане право, розмір й порядок виплати авторської винагороди та інші умови» [5, с. 11].

Водночас варто зазначити, що лише укладанням трудового договору або цивільно-правового договору, у якому будуть зазначені всі питання, що стосуються розподілу майнових прав на об'єкт інтелектуальної власності, що створений у зв'язку з виконанням цього договору, недостатньо. Передусім необхідно усунути колізії у законодавстві, а для вирішення цього питання необхідно звернутися до судової практики.
Як свідчить судова практика, відповідно до Постанови Пленуму Верховного Суду України від 04.06.2010 № 5 «Про застосування судами норм законодавства у справах про захист авторського права і суміжних прав» суди під час розгляду справ керуються такими положеннями: майнові права на об'єкт авторського права і (або) суміжних прав, створений у зв'язку з виконанням трудового договору, належать працівникові, який створив цей об'єкт, та юридичній або фрізичній особі, де або в якої він працює, спільно, якщо інше не встановлено договором [4]. 3 огляду на судову практику застосування норм законодавства вбачається, що для усунення колізій у законодавстві необхідно зміст ч. 2 ст. 16 Закону України «Про авторські права і суміжні права» привести у відповідність до ч. 2 ст. 429 ЦК України.

Проте, на думку О.О. Штефан, щоб вирішити це питання необхідно: «....зміст ч. 2 ст. 429 ЦК України привести у відповідність до ч. 2 ст. 16 Закону України «Про авторське право і суміжні права», оскільки «...спеціальне авторське законодавство більш чітко визначає правовий статус суб'єктів зазначених правовідносин, а також надає право автору передати роботодавцю не весь комплекс майнових прав, пов'язаних із використанням службового твору...» [6, с. 107].

Висновки. 3 огляду на вищезазначене можна зробити висновок, що правове регулювання права інтелектуальної власності на твір, створений у процесі виконання трудового договору, потребує детального вивчення та однозначного закріплення на законодавчому рівні. Правові колізії у законодавстві сприяють збільшенню кількості порушення виключних майнових прав авторів на створені ними твори у процесі їх трудової діяльності. Задля усунення наявних прогалин у законодавстві пропонуємо спиратися на судову практику з вирішення спорів, що стосуються права інтелектуальної власності, хоча в Україні судовий прецедент не $€$ джерелом права, але судді, здійснюючи розгляд справ, можуть звертатися до нього як до додаткового джерела інформації. Крім того, варто зауважити, що особливе місце у розподілі прав інтелектуальної власності на службові твори займають: трудовий договір та цивільно-правові договори. Саме під час укладання договору необхідно чітко прописати усі моменти, що стосуються особистих немайнових та майнових прав працівника та роботодавця на службовий твір. Такий підхід сприятиме уникненню випадків порушення прав інтелектуальної власності, а в разі такого порушення стане дієвим способом захисту порушеного права.

\section{Список використаних джерел:}

1. Цивільний кодекс України від 16.01.2003 року № 435-IV / BP України. URL: https://zakon.rada.gov.ua/laws/ show/435-15 (дата звернення 08.11.2019). 
2. Про авторське право і суміжні права від 23.12.1993 року № 3792-XII / ВР України. URL: https://zakon.rada. gov.ua/laws/show/3792-12 (дата звернення 08.11.2019).

3. Іларіон Томаров. Винагорода за створення і використання службового твору. URL: http://www.legalshift.com. $\mathrm{ua} / \mathrm{p}=1266$.

4. Про застосування судами норм законодавства у справах про захист авторського права і суміжних прав. Постанова Верховного Суду від 04.06.2010 року / ВР України. URL: https://zakon.rada.gov.ua/laws/show/ v0005700-10 (дата звернення 08.11.2019).

5. Єпіфанова Ю.С. Авторські права науково-педагогічних працівників вищих навчальних закладів : автореф. дис. ... канд. юрид. наук : спец. 12.00.03. «Цивільне право та цивільний процес, сімейне право, міжнародне приватне право». Харків, 2010. 17 с. URL: file://C:/Users/User/Downloads/Telegram\%20Desktop/avtors_ki_prava_ naukovo_pedagogichnih_pr.pdf.

6. Штефан О.О. Проблеми правового статусу суб'єктів «службового» твору. Приватне право і підприємниųтво : збірник наукових праць. 2009. № 8. C. 105-108. URL: http://library.nlu.edu.ua/POLN_TEXT/SBORNIKI_2010/ PPP_8_2009/Shtefan.pdf. 
УДК 347.9; 346

DOI https://doi.org/10.37687/2413-6433.2020-1.10

Петрова I.A.,

доктор юридичних наук, професор, головний науковий співробітник

Харківського науково-дослідного інституту судових експертиз імені заслуженого професора М.С. Бокаріуса ORCID: 0000-0002-1652-6715

Силенок К.П.,

науковий співробітник

Харківського науково-дослідного інституту судових експертиз імені заслуженого професора М.С. Бокаріуса

ORCID: 0000-0001-9355-5010

Чекін Д.О.,

науковий співробітник

Харківського науково-дослідного інституту судових експертиз імені заслуженого професора М.С. Бокаріуса

ORCID: 0000-0002-9893-1588

\section{МЕДІАЦІЯ ЯК ФОРМА ВИКОРИСТАННЯ СПЕЦІАЛЬНИХ ЗНАНЬ У ЦИВІЛЬНОМУ ТА ГОСПОДАРСЬКОМУ ПРОЦЕСІ}

\section{MEDIATION AS A FORM OF USE OF SPECIAL KNOWLEDGE IN CIVIL AND ECONOMIC PROCESS}

У статті розглянуто основні положення медіації як форми використання спеціальних знань у цивільному та господарському процесі. Попри відсутність в Україні профільного закону, медіація стає важливим елементом цивільного та господарського судочинства, саме тому надзвичайно важливим є створення ефективної нормативної бази у цій сфері. Авторами досліджено нормативно-правові акти, що регулюють основні положення та процедуру медіації в світі та в Україні. Увага приділяється проєкту Закону України «Про медіацію», який розроблено 3 метою створення законодавчого підгрунтя для успішного розвитку медіації в Україні відповідно до кращих світових практик. Прийняття цього Закону закріпить на законодавчому рівні можливість проведення процедури медіації, яка полягатиме у добровільному позасудовому врегулюванні спору шляхом переговорів між його сторонами за допомогою медіатора.

У статті охарактеризовано процедуру медіації як ефективного способу примирення сторін, що широко розповсюджений і активно застосовується багатьма країнами. Розгалужена система міжнародно-правових документів щодо медіації підкреслює важливу роль цього механізму для вирішення спорів. Навіть більше, у країнах Європи більшість спорів вирішуються без судового розгляду саме за процедурою медіації. Адаптація українського законодавства до стандартів Свропейського Союзу позитивним чином вплине на подальший розвиток України як частини європейського простору. Обгрунтовано актуальність правового унормування медіації як форми використання спеціальних знань у цивільному та господарському процесі, що у значно коротший час зможе забезпечити дотримання законних прав та інтересів сторін спору. Зроблено висновок, що медіація в цивільних справах та господарських спорах є останньою можливістю сторін повернутися до конструктивних перемовин, узгодити спірні питання 3 тим, щоб у майбутньому забезпечити подальшу співпрацю та уникнути небажаних наслідків для обох сторін.

Ключові слова: спеиіальні знання, медіачія, мирова угода, иивільне судочинство, господарське судочинство.

The article considers the main provisions of mediation as a form of using special knowledge in civil and commercial proceedings. Despite the lack of a relevant law in Ukraine, mediation is becoming an important element of civil and commercial litigation, and therefore it is extremely important to create an effective regulatory framework in this area. The authors consider the regulations governing the basic provisions and procedure of mediation in the world and in Ukraine. Attention is paid to the draft Law of Ukraine "On Mediation", which is designed to create a legal basis for the successful development of mediation in Ukraine in accordance with world best practices. The adoption of this law will enshrine at the legislative level the possibility of conducting a mediation procedure, which will consist of voluntary out-of-court settlement of the dispute through negotiations between its parties, with the assistance of a mediator.

The article describes the mediation procedure as an effective way of reconciling the parties, which is widespread and actively used by many countries. The extensive system of international legal instruments on 
mediation emphasizes the important role of this mechanism for resolving disputes. Moreover, in European countries, most disputes are resolved without trial through the mediation procedure. Adaptation of Ukrainian legislation to the standards of the European Union will have a positive impact on the further development of Ukraine as part of the European space. The relevance of legal regulation of mediation as a form of using special knowledge in civil and commercial proceedings is substantiated, which in a much shorter time will be able to ensure compliance with the legal rights and interests of the parties to the dispute. It is concluded that mediation in civil cases and commercial disputes is the last opportunity for the parties to return to constructive negotiations, to agree on contentious issues in order to ensure further cooperation in the future and to avoid undesirable consequences for both parties.

Key words: special knowledge, mediation, amicable agreement, civil proceedings, commercial proceedings.

Необхідність впровадження медіації засвідчується значною кількістю нормативно-правових актів і концептуальних документів, що підтримуються міжнародною спільнотою та прийняті в Україні. Досвід застосування медіації в межах пілотних проєктів за кордоном та в Україні вказує на досить високу ефективність подібного способу вирішення різного роду конфліктів і спорів у різних галузях правовідносин. Теоретичному дослідженню впровадження медіації у різні сфрери судочинства присвячено низку напрацювань вітчизняних науковців, що знайшли своє відображення у результатах дисертаційних досліджень.

Так, у дисертаційному дослідженні Р.Ф. Аракелян були розглянуті теоретичні та практичні аспекти впровадження інституту медіації в кримінальне процесуальне законодавство України, охарактеризовано теоретичні та історичні засади медіації в системі відновного правосуддя України. На основі здійсненого правового аналізу поняття та значення інституту медіації у кримінальному процесі висвітлено та систематизовано принципи та моделі медіації у кримінальному процесі. На підставі узагальнених результатів дослідження запропоновано теоретико-прикладні засади впровадження медіації в кримінальне процесуальне законодавство України. Також авторкою визначено, що «медіація в кримінальному провадженні повинна поглинути все напруження та знайти баланс між необхідністю встановлення та осуду кримінального діяння без будь-яких сумнівів, з одного боку, а з іншого - «надати руку допомоги» підозрюваному чи обвинуваченому з тим, щоб допомогти встановити соціальні зв'язки, які виявилися втраченими» [1].

Дисертацію С.О. Корінного присвячено дослідженню адміністративно-правового забезпечення медіації як способу вирішення адміністративних спорів, аналізу теоретичних засад упровадження медіації в Україні з урахуванням відповідної зарубіжної практики, а також шляхів удосконалення нормативно-правового забезпечення медіації у вітчизняному адміністративному процесі. Науковцем розкрито ґенезу інституту медіації, з'ясовано його сутність, структуру й особливості, визначено правову основу медіації як способу вирішення адміністративних спорів, а також види медіативної практики [2].
Дисертаційним дослідженням T.I. Шинкар було обґрунтовано доцільність запровадження медіації в адміністративному судочинстві як одного $з$ найбільш дієвих видів альтернативного вирішення юридичних спорів, віднесених до компетенції адміністративного суду; розкрито сутність альтернативного вирішення спорів як можливої нової сфери профресійної діяльності судді-медіатора під час вирішення юридичних спорів в адміністративному судочинстві; обґрунтовано допустимість виконання суддею ролі медіатора і розглянуто медіативну діяльність судді як можливий принципово новий самостійний вид суддівської діяльності [3].

Розвиток медіації у кримінальному процесі було висвітлено у заключному документі грантової програми «Сприяння практичному запровадженню медіації в Україні та налагодженню взаємодії з судовою системою», де було зазначено, що «судді, прокурори та інші органи кримінального правосуддя відіграють важливу роль у розвитку медіації. Вони мають бути у змозі надавати інформацію, проводити спеціальні інформаційні заходи з питань медіації та у разі можливості пропонувати потерпілим i/або правопорушникам скористатися медіацією і/або передавати справи на медіацію. Державам-членам рекомендується започаткувати i/або посилювати співпрацю між органами кримінальної юстиції та службами медіації задля ефективнішого охоплення потерпілих та правопорушників медіаційними послугами» [4].

Зауважимо, що світові тенденції впровадження в правову систему України такого альтернативного виду вирішення спорів, як медіація, знайшли відображення у вітчизняному законодавстві тільки у вигляді цивільно-правових, господарсько-правових і сімейно-правових відносин. Наприклад, В. Жмудь підкреслює, що про доцільність запровадження процедури медіації як примирення у цивільному та господарському судочинстві свідчить низка документів, серед яких: Рекомендації Комітету Міністрів Ради Європи «Про медіацію в цивільних справах» (R № (2002) 10) та «Про сімейну медіацію» (R № (98) 1), а також «Зелена книга» про альтернативне врегулювання спорів у цивільному та комерційному праві Комісії Європейських Співтова- 
риств, Типовий закон ЮНІСТРАЛ «Про міжнародну комерційну примирювальну процедуру 3 наставником» щодо впровадження й застосування (2002) тощо [5].

Поняття «медіація» походить від латинського "mediare", що означає «бути посередником». У перекладі з англійської мови термін медіація (mediation) - означає посередництво, клопотання, заступництво. Формальне визначення медіації міститься у ст. 1 Типового закону ЮНСІТРАЛ (Комісії ООН 3 міжнародного торгового права) 2002 року щодо міжнародних комерційних арбітражних процедур, згідно з якою медіація може бути визначена як «процес, коли сторони залучають третю особу або осіб з метою надання ними допомоги у мирному врегулюванні спорів, що виникають щодо контрактних чи інших правових відносин або пов'язані $з$ ними. Мировий посередник не має права нав'язувати сторонам способи врегулювання спору» [6].

Проєкт Закону України «Про медіацію» наводить таке визначення: «медіація - позасудова процедура врегулювання конфрлікту (спору) шляхом переговорів сторін конфлікту (спору) за допомогою одного або декількох медіаторів. 3 огляду на питання, що нами розглядаються, особливо цікавим $є$ визначення особи (спеціаліста), який володіє спеціальними знаннями та використовує їх за фрахом». Автори проєкту Закону вважають, що «медіатор - це спеціально підготовлений посередник, який сприяє сторонам конфрлікту (спору) в його врегулюванні шляхом структурованого переговорного процесу» [7].

Сучасна концепція системи врегулювання спорів у цивільному та господарському процесі, зокрема й шляхом медіації, базується на інноваційному плюралістичному підході та заохочує сторони до самостійного пошуку взаємоприйнятних рішень, оскільки змагальні методи врегулювання спорів у судах нерідко $€$ економічно досить витратними як для держави, так і для суб'єктів господарської діяльності, а для пересічних громадян і поготів. Зарубіжний досвід свідчить, що медіація $є$ не тільки засобом «розвантаження» судової системи у процесі розгляду цивільних, сімейних, господарських, адміністративних справ або кримінальних проваджень, але й засобом зменшення ризиків виникнення конфрліктів [8].

Сьогодні існує ціла низка міжнародно-правових документів щодо медіації. За лінією $\mathrm{OOH}$ це: Резолюція Економічної та Соціальної Ради ООН від 4 травня 1999 р. «Розробка та здійснення засобів посередництва та поновлювального правосуддя в галузі кримінального правосуддя»; Резолюція Економічної та Соціальної Ради ООН від 24 липня 2002 р. «Головні принципи застосування програм відновного правосуддя в кримінальних справах»; Бангкокська декларація «Взаємодія та зворотні заходи: стратегічні союзи в галузі попередження злочинності та кримінального правосуддя», прийнята на 11-му Конгресі ООН з питань попередження злочинності та кримінального правосуддя (Бангкок, Таїланд, 18-25 квітня 2005 р.). За лінією Європейського Союзу та Ради Європи: Рекомендація № R (99) 19 Комітету Міністрів Ради Європи про медіацію у кримінальних справах та інші від 15 вересня 1999 р.; Основоположне рішення Ради Європейського Союзу про місце жертв злочинів у кримінальному судочинстві (2001/220/JHA) від 15 березня 2001 р.; Рекомендація № R (98) 1 Комітету Міністрів Ради Європи державам-членам щодо медіації у сімейних справах; Рекомендація Rec (2002) 10 Комітету Міністрів Ради Європи державам-членам щодо медіації у цивільних справах; Рекомендація $\operatorname{Rec}(2003) 20$ Комітету Міністрів Ради Європи державам-членам щодо нових способів роботи зі злочинністю неповнолітніх і ролі правосуддя у справах неповнолітніх; Європейський кодекс поведінки медіатора (European Code of Conduct for Mediators), прийнятий на конференції, організованій Директоратом Європейської Комісії з питань юстиції 02.07.2004 р. у м. Брюссель; Рекомендація $\operatorname{Rec}(2006) 8$ Комітету Міністрів Ради Європи державам-членам щодо надання допомоги потерпілим від злочинів; Директива 2008/52/€С Європейського Парламенту та Ради Європейського Союзу від 21 травня 2008 р. «Про деякі аспекти медіації у цивільних і господарських правовідносинах» [9].

Слід наголосити, що такі зусилля Ради Європи активно підтримуються рішеннями Європейського Союзу, який 2008 року ввів у дію Директиву $з$ медіації, що вважається інструментом до скорочення витрат і часу на розгляд цивільних спорів, особливо комерційних спорів транскордонного характеру. Як відомо, директива $є$ законодавчим актом, що $є$ обов'язковим до виконання в аспекті досягнення результату, при цьому держави - члени ЄС мають право обирати форму та спосіб ії̈ імплементації з урахуванням особливостей національної правової системи та правових традицій. Директива забезпечує доступ медіації до правосуддя, наділяє суди правом пропонувати сторонам спору процедуру медіації, зберігаючи за ними право відмовитися від медіації без будь-яких санкцій та звертатися до суду; дозволяє сторонам ухвалювати рішення, що виконуються безпосередньо в суді; захищає медіаторів від вимоги виступати в ролі свідків (за винятком справ значної суспільної ваги) тощо [9].

Крім цього, Директива заохочує держави членів $€ С$ до забезпечення навчання та перепідготовки медіаторів, розробки та прийняття етичних кодексів медіаторів і заходів з контролю за якістю медіаційних послуг, поширення інформації про послуги медіаторів та агенції, 
що такі послуги надають. Положення про медіацію знайшли місце також і в конвенційних документах, зокрема в ст. 13 Європейської конвенції про здійснення прав дітей (СЕД № 160) [10]. Попри те, що рекомендації Комітету міністрів не $є$ юридично обов'язковими актами і складають так зване "м'яке право», вкрай важливим $\epsilon$ те, що вони приймаються за переконливою згодою усіх держав - членів організації та розповсюджуються на всіх держав-членів. Отже, поступово, без формальних і тривалих процедур ратифікації (на відміну від положень конвенцій та угод), рекомендації РЄ стають нормами національного законодавства та практики великої кількості європейських держав.

Слід підкреслити, що успіх процесу медіації залежить також і від того наскільки враховані потреби особи, щодо якої медіація застосовується. Оскільки потреби визначають добробут та якість життя, їх можна вважати найсильнішими мотиваторами дій людини. На задоволення найбільш актуальних потреб особи спрямовані її поведінка та вчинки у кожний момент часу, оскільки коли потреба задоволена, особа відчуває задоволення від життя. Можна припустити, що люди мають подібні потреби, однак рівень інтенсивності відчуття власних потреб відрізняється не тільки у різні проміжки часу, але й у різних осіб. Враховуючи, що потреби $€$ проявом глибинної загальновизнаної людяності, підкреслимо, що розуміння власних потреб дає краще розуміння та визначення цінностей, якими керується людина, а також краще розуміння та зв'язок з іншими людьми. Розпізнавати потреби, що є важливими у процесі медіації, пропонують за особливими якостями, що їм притаманні, а саме:

- $€$ універсальними для всіх, незалежно від віку, статі, освіти, статусу тощо (наприклад, потреба безпеки, любові, поваги тощо);

- $є$ рівноцінними, оскільки потреби однієї особи не можуть бути більш пріоритетними за потреби іншої особи;

-є взаємозалежними, тому що жодна особа не здатна задовольнити власні потреби за рахунок іншої без наслідків, які обом можуть не сподобатись;

- глибина потреба особи не стосується конкретного місця чи часу, іншої людини, об'єкту або дії;

- потреби відрізняються у різних людей навіть у схожих ситуаціях, оскільки кожна ситуація є індивідуальною [4].

Для медіатора важливим $є$ розуміння того, що почуття тієї чи іншої людини в окремий момент часу $є$ прямим наслідком задоволення чи незадоволення її потреб. Важливим $€$ те, що особа, яка розуміє власну реакцію на ту чи іншу подію крізь призму потреб, бере на себе відповідальність за свій стан і почуття, що вберігає і її, і навколишніх осіб від помилок в обранні подальших дій. Вміння розуміти глибинні потреби як мотиватори усіх власних дій та дій інших осіб слід покласти в основу процесу медіації.

Ефективність медіації визнана європейським співтовариством, і рекомендовано їі впровадження як основного методу альтернативного вирішення спорів у цивільному та господарському процесі. Наприклад, у країнах Європи 80\% спорів, що перебувають у провадженні суду і передаються на медіацію, вирішуються без судового розгляду. У США, країні, що дуже активно використовує ці способи під час вирішення цивільно-правових спорів, медіацію використовують 3 60-х років XX ст. Основою формування цього способу стали застосовувані ще квакерами та єврейськими громадами (типу Jewish Conciliation Board) способи втручання (інтервенції) у різні види конфліктів - спори про спадкування, власність або з питань сімейного права - що своєю чергою брали початок 3 давньоєврейських традицій. у 1982 р. в США було вже понад 300 осіб і організацій, що займалися медіацією під час врегулювання сімейних конфліктів [11]. При цьому світовий досвід свідчить, що понад 90\% укладених договорів за результатами медіації були виконані, а близько 80,0\% правопорушників, які брали участь у відновних процедурах, не вчиняли нових злочинів [12, с. 167].

У процесуальному законодавстві України (цивільному та господарському) останнім часом досить активно запроваджуються норми ювенальної юстиції та відновлюваного правосуддя. Тому в судах поза кримінально-правовою сферою має стати розширення сорери застосування процедур відновлюваного правосуддя, відповідно до яких суд прийматиме рішення щодо угоди про примирення (мирової угоди) сторін у цивільному та господарському процесі. У чинному законодавстві активно використовується це положення. Зокрема, статті 207 ЦПК та 192 ГПК України («Мирова угода сторін») передбачають, що мирова угода укладається сторонами з метою врегулювання спору на підставі взаємних поступок і має стосуватися лише прав та обов'язків сторін. У мировій угоді сторони можуть вийти за межі предмета спору за умови, що мирова угода не порушує прав чи охоронюваних законом інтересів третіх осіб. Сторони можуть укласти мирову угоду та повідомити про це суд, зробивши спільну письмову заяву, на будь-якій стадії судового процесу [13; 14].

Таким чином, медіація в цивільних справах та господарських спорах є останньою можливістю сторін повернутися до конструктивних перемовин, узгодити спірні питання з тим, щоб у майбутньому забезпечити подальшу співпрацю та уникнути небажаних наслідків для обох сторін. 
Список використаних джерел:

1. Аракелян Р.Ф. Впровадження інституту медіації в кримінальне процесуальне законодавство України : дис. ... канд. юрид. наук : 12.00.09. Київ. 2019. 331 с.

2. Корінний С.О. Впровадження медіації в адміністративний процес України : дис. ... канд. юрид. наук : 12.00.07. Ужгород. 2019. 243 с.

3. Шинкар Т.I. Застосування медіації в адміністративному судочинстві: вітчизняний та зарубіжний досвід : дис. ... канд. юрид. наук : 12.00.07. Київ. 2017, 220 с.

4. Практичне застосування медіації : практ.-метод. посібн. викладача. Київ. 2016. URL: https:/newjustice.org.ua/ wp-content/uploads/2018/05/Curriculum_Mediation_print.pdf (дата звернення 17.08.2020).

5. Жмудь В. Запровадження процедури медіації (примирення) у законодавстві України. URL: https://minjust.gov.ua/m/str_11347 (дата звернення 17.08.2020).

6. Веб-сайт «Лига медиаторов». URL: http://arbimed.ru. Заголовок с екрана (дата звернення 10.08.2020).

7. Про медіацію: проект Закону від 17.12.2010. № 7481 URL: http://rada. gov.ua/pls/zweb2/webproc (дата звернення 10.08.2020).

8. Медіація як процедура врегулювання спорів шляхом досягнення консенсусу. Інститут законодавства Верховної Ради України; Мюнхенський Інститут східноєвропейського права. Київ : Інститут законодавства Верховної Ради України, 2011. 236 с.

9. Официальный веб-сайт Международной Посреднической Корпорации (International Mediation Corporation). URL: http://intermediation.narod.ru. (дата звернення 10.08.2020).

10. Про здійснення прав дітей. Європейська конвенція. URL: http://conventions.coe.int. Заголовок з екрана (дата звернення 10.08.2020).

11. Притика Ю. Медіація, як спосіб вирішення цивільно-правових спорів. URL: http://ilandmanagement.com. Заголовок з екрана (дата звернення 10.08.2020).

12. Маляренко В.Т. Кримінальний процес України: стан та перспективи розвитку : навч. посіб. для студ. вищ. навч. закл. Київ : Концерн «Видавничий Дім «Ін Юре», 2004. 600 с

13. Цивільний процесуальний кодекс України: Закон України від 18.03.2004. № 1618-VI (зі змінами та доповненнями) Відомості Верховної Ради України (ВВР), 2004, № 40-41, 42, ст. 492;

14. Господарський процесуальний кодекс України: Закон України від 06.11.1991 № 1798-XII (зі змінами та доповненнями) Відомості Верховної Ради України (ВВР), 1992, № 6, ст. 56. 
УДК 347.121 .1

DOI https://doi.org/10.37687/2413-6433.2020-1.11

Салманова К.В.,
здобувач Навчально-наукового інституту права
Університету державної фіскальної служби України
ORCID: 0000-0002-4942-7131

Дяченко С.В.,

кандидат юридичних наук, доцент,

доцент кафедри цивільного права та процесу

Університету державної фіскальної служби України

ORCID: 0000-0002-0104-2769

\section{ПРАВО ФІЗИЧНОЇ ОСОБИ НА ДОНОРСТВО ЯК ОСОБИСТЕ НЕМАЙНОВЕ ПРАВО. СУДОВИЙ ЗАХИСТ}

\section{THE RIGHT OF AN INDIVIDUAL TO DONATE AS A PERSONAL NON-PROPERTY RIGHT. JUDICIAL PROTECTION}

У статті досліджуються правовідносини у сфері захисту особистого немайнового права фізичної особи на донорство в порядку цивільного судочинства.

В процесі дослідження аналізуються особливості цивільно-правового регулювання права на донорство, формується чітке розмежування негативних наслідків, які мають місце під час реалізації права на донорство, та розглядаються можливі форми захисту вказаного права, акцентується увага на юрисдикційній формі захисту.

Проведений аналіз даних інформаційної системи «Єдиний державний реєстр судових рішень» дає можливість сформувати чітке розуміння того, що в Україні на цей час звернення до суду для захисту свого особистого немайнового права на донорство $є$ досить поширеним явищем. Водночас встановлено широке коло проблемних питань, з якими суб'єкти досліджуваних правовідносин звертаються до суду, що насамперед спричинене особливостями як суб'єктного, так і об' єктного складу правовідносин.

Особлива увага в дослідженні зосередилась на спорах щодо: відшкодування моральної та матеріальної шкоди; трудових спорах, пов’язаних з реалізацією права на донорство та незаконним звільненням через прогул; встановлення факту належності правовстановлюючого документу Почесного донора особі, яка бажає отримати пільги, встановлені законодавством через її статус; встановлення факту родинних відносин між майбутніми донором та реципієнтом.

На основі проведеного дослідження у роботі констатується, що судова практика захисту особистого немайнового права на донорство здійснюється з дотриманням процесуального законодавства та на основі принципу верховенства права, що відповідає європейським стандартам. Наводяться пропозиції щодо дієвих механізмів популяризації здійснення права на донорство, зокрема на альтруїстичних засадах. Встановлюються основні вектори державної політики, які покликані вирішити ряд проблемних питань, з якими стикаються суб'єкти згаданих вище правовідносин.

Ключові слова: право на донорство, донор, реципієнт, принцип верховенства права, судова практика, судовий захист.

The article examines the legal relationship in the field of protection of personal non-property right of an individual to donate in civil proceedings.

In the course of the work the peculiarities of civil law regulation of the right to donation are analyzed, a clear distinction of negative consequences is formed during the realization of the right to donation and possible forms of protection of this right are considered, attention is focused on jurisdictional protection.

The analysis of the data of the information system Unified State Register of Court Decisions provides an opportunity to form a clear understanding that in Ukraine today recourse to the court to protect their personal non-property right to donate is quite common. However, a wide range of problematic issues has been identified with which the subjects of the studied legal relations apply to the court, which is primarily caused by the peculiarities of both the most subjective and object composition of the legal relations.

The study focused on disputes concerning: compensation for moral and material damage; labor disputes related to the exercise of the right to donate and illegal dismissal due to absenteeism; establishing the fact that the rightestablishing document of the Honorary Donor belongs to a person who wishes to receive benefits established by law due to his status; establishing the fact of family relations between the future donor and recipient.

Based on the study, the paper states that the judicial practice of protecting the personal non-property right to donate is carried out in compliance with procedural law and on the basis of the rule of law, which meets European standards. Suggestions are made for effective mechanisms to promote the exercise of the right to donate, in particular on an altruistic basis. The main vectors of state policy are established, which are designed to solve a number of problematic issues faced by the subjects of the above-mentioned legal relations.

Key words: right to donate, donor, recipient, principle of rule of law, judicial practice, judicial protection. 
Постановка проблеми. Оцінка ефективності діяльності держави напряму залежить від стану дотримання особистих немайнових прав людини в країні, зокрема права на донорство.

3 кожним днем стає зрозумілим, що суспільні відносини знаходяться в непереривній динаміці та потребують постійного реформування у правовому полі. Надзвичайно важливою $є$ галузь охорони здоров'я, адже життя та здоров'я $є$ найвищим суспільним благом.

Вітчизняна законодавча база у сфері донорства не $є$ досконалою та не повністю відповідає сучасним реаліям й потребам суспільного життя. У зв'язку з цим сьогодні одним із пріоритетних напрямів розвитку правової бази в України має бути регулювання, захист та охорона згаданого комплексу прав.

Відтак, поряд зі зростаючою медичною потребою, у законодавстві, яке регулює сфреру донорства, зростає коло проблемних аспектів. Неефективність певних правових механізмів, які використовує держава під час регулювання правовідносин у сфрері донорства, зумовлює необхідність звернення фрізичної особи до суду за захистом свого немайнового права на донорство.

Аналіз останніх досліджень і публікацій. На сучасному етапі аналіз проблем правового регулювання права на донорство як особистого немайнового права фрізичної особи та, зокрема, питання ефективності судового захисту зазначеного права містяться у наукових доробках

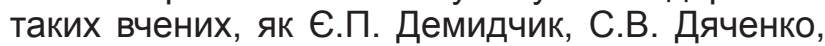
А.А. Герц, З.Л. Волож, Ф.В. Дахно, В.С. Корсак, К.В. Ільющенко та інших.

Мета статті - шляхом опрацювання судової практики щодо певної категорії справ дослідити правову природу захисту особистого немайнового права фрізичної особи на донорство в порядку цивільного судочинства через призму реалізації принципу верховенства права.

Виклад основного матеріалу. В статті 3 Конституції України закріплено: «Людина, її життя і здоров'я, честь і гідність, недоторканність і безпека визнаються в Україні найвищою соціальною цінністю. Права і свободи людини та їх гарантії визначають зміст і спрямованість діяльності держави»; у стаття 49 зазначається: «Кожен має право на охорону здоров'я, медичну допомогу та медичне страхування»; стаття 50 передбачає, що права і свободи людини і громадянина захищаються судом [1].

У законодавчій базі України донорство регламентується статтею 290 Цивільного Кодексу України (далі - ЦК України), де зазначається, що «повнолітня дієздатна фрізична особа має право бути донором крові, ії компонентів, а також органів та інших анатомічних матеріалів та репродуктивних клітин» [2].

Крім вищезгаданого кодифрікованого акту, право на донорство, залежно від об'єктного складу цих правовідносин, регулюється низкою спеціальних законодавчих актів, до яких належать: Закон України «Про донорство крові та її компонентів», Закон України «Про застосування трансплантації анатомічних матеріалів людині», наказ МОЗ № 787 від 09.09.2013p. «Про затвердження Порядку застосування допоміжних репродуктивних технологій в Україні» тощо.

Відтак право фрізичної особи на донорство являє собою особисте немайнове право, що непорушно пов'язане зі здоровим існуванням людини в соціумі, тому важливість фрормування державою чітких форм та способів захисту права на донорство важко переоцінити.

Захист особистих немайнових прав - це комплекс превентивних дій, які спрямовані на запобігання порушення власного права або ж усунення чинників, які спричиняють порушення немайнових прав фрізичної особи, а у разі настання такого порушення - це дії щодо оцінки завданої шкоди та отримання як моральної, так і матеріальної компенсації.

Досліджуючи питання захисту донором свого права на здоров'я, важливо зазначити, що він являється особливим суб'єктом цих правовідносин, адже державою передбачено граничний показник правомірного завдання шкоди зазначеному суб'єкту та порядок відшкодування настання негативних наслідків.

Загалом до негативних наслідків, які мають місце під час реалізації права на донорство, можна віднести:

- очікувану шкоду, тобто передбачені самим донором негативні наслідки;

- непередбачену шкоду (певні ускладнення під час процесу донації, яких донор не очікував, наприклад, реакція організму донора, помилка лікарів у процесі проведення донації, неправомірне звільнення з роботи через пропуск тощо). Саме цей вид негативних наслідків потребує більш глибокого аналізу для розуміння правової природи їх настання та часто стає приводом для звернення до суду.

Загалом вітчизняним законодавством передбачено, що фрізична особа у разі порушення права на донорство може обрати:

- юрисдикційну форму захисту, яка полягає у зверненні до уповноваженого державного органу, тобто суду;

- неюрисдикційну фрорму, яка проявляється через самозахист (прикладом може слугувати укладання договору особистої охорони). Доцільно наголосити, що ч. 2 ст. 19 ЦК зазначено, що «способи самозахисту мають відповідати змісту права, що порушене, характеру дій, якими воно порушене, а також наслідкам, що спричинені цим порушенням» [2].

Щодо юрисдикційної форми захисту необхідно зазначити, що загалом судовий захист права на донорство здійснюється в порядку адміністративного, кримінального та цивіль- 
ного судочинства. При цьому питання щодо здійснення захисту права на донорство крові та їі компонентів врегульоване відповідно до ст. 20 Закону України «Про донорство крові та її компонентів», в якій закріплено, що «Особи, винні у порушенні встановлених цим Законом прав донорів, порядку взяття, переробки, зберігання, реалізації та застосування донорської крові, її компонентів та препаратів, порядку контролю за безпекою та якістю донорської крові, її компонентів, препаратів та відповідних консервуючих розчинів, порядку обміну донорською кров'ю, її компонентами і препаратами та вивезення їх за межі України, порядку медичного обстеження донора перед здаванням крові та (або) їі компонентів, несуть встановлену законодавством дисциплінарну, адміністративну, цивільно-правову чи кримінальну відповідальність» [3].

Взявши за основу дослідження судову практику в площині саме цивільного судочинства, доцільно звернути увагу на ч. 2 ст. 2 Закону України «Про донорство крові та її компонентів» в аспекті визначення протипоказань до донорства крові та її компонентів, яка свого часу була конкретизована наказом МО3 України від 01.08.2005p. №385 «Про інфекційну безпеку донорської крові та її компонентів» та все ж не в повною мірою знайшла діючий механізм практичного застосування [4].

3 огляду на вищенаведене переконливим прикладом слугує Постанова Верховного Суду України від 15 листопада 2018 р. №761/24076/15- ц про відшкодування моральної шкоди та матеріальної шкоди, завданої внаслідок зараження дитини ВІЛ-інфекцією. Відтак для чіткого розуміння суті справи коротко наведемо обставини: у серпні 2015 року ОСОБА 4, яка діє в інтересах свого неповнолітнього сина ОСОБА_5, звернулася до суду з позовом до Київського міського центру крові Департаменту охорони здоров'я Виконавчого органу Київської міської ради (Київської міської державної адміністрації) (далі - Київський міський центр крові, Центр), Міністерства охорони здоров'я України (далі - МО3 України), Київської міської державної адміністрації (далі - КМДА) про відшкодування моральної шкоди та матеріальної шкоди, завданої внаслідок зараження дитини ВІЛ-інфекцією, а також встановлення вини центру переливання крові та МО3 України. Рішення Шевченківського районного суду міста Києва від 21 грудня 2017 року частково задовольнило позовні вимоги ОСОБА 4, мотивуючи це тим, що зараження в лікувальному закладі дитини позивача невиліковною хворобою сталося через неналежну організацію проведення обстеження крові донора, зменшивши при цьому розмір виплати моральної шкоди. Постановою Апеляційного суду міста Києва від 15 березня 2018 року рішення Шевченківського районного суду міста Києва від 21 грудня було залишено без змін та вмотивовано тим, що під час розгляду справи було встановлено фракт зараження сина позивача ОСОБА_5. При цьому у касаційній скарзі МО3 України та Київського міського центру крові йдеться про скасування судових рішень судів першої та апеляційної інстанцій в частині стягнення 3 MO3 України моральної та матеріальної шкоди і ухвалення в цій частині нового рішення про відмову у задоволенні позову, посилаючись на неправильне застосування судами норм матеріального права та порушення норм процесуального права. Верховний Суд у своїй постанові зауважує, що спеціальне законодавство, яке встановлює порядок відшкодування моральної шкоди, заподіяної третім особам в зв'язку з негативними наслідками проведених медичних маніпуляцій, та покладає відповідальність за таку шкоду на державу, в Україні відсутнє. Тому відшкодування заподіяної ОСОБА 4 моральної шкоди здійснюється на загальних підставах, встановлених статтею 1167 ЦК України, тобто безпосередньо тими особами, які вказану шкоду завдали [5].

Примітним $\epsilon$ те, що під час вирішення наведеної вище справи Верховний Суд керувався рішенням Європейського суду з прав людини у справі «Арская проти України» від 05.02.2014, де зазначено, що органи державної влади повинні вживати достатніх заходів для створення нормативно-правової бази, яка б забезпечила належний захист життя особи, як того вимагає стаття 2 Конвенції про захист прав людини та основоположних свобод [6], яка закріплює право кожного на життя [5]. Це свідчить про те, що під час розгляду справ судами у сфері реалізації фрізичною особою права на донорство використовується практика Європейського суду з прав людини, що є безперечно позитивним фоактом.

Важливо зазначити, що відповідно до трудового законодавства, а саме статті 124 Кодексу законів про працю України [7] та ст.ст. 9, 10, 11 Закону України «Про донорство крові та її компонентів», донорам крові та її компонентів надаються пільги, до яких можна віднести: «вихідний день у день здавання та медичних обстежень, забезпечення сніданком та обідом за рахунок закладу охорони здоров'я, додатковий день відпочинку за кожен день здавання крові, а у разі систематичного безоплатного здавання крові та її компонентів - 100\% оплата лікарняних протягом року та незалежно від стажу, додаткове нарахування 25\% стипендії протягом півроку та 25\% грошового забезпечення військовослужбовців та курсантів» [3].

Аналіз судової практики свідчить, що спори у сфері реалізації фрізичною особою свого особистого немайнового права на донорство тісно пов'язані із трудовими правовідносинами. Так, у справі № 644/6005/16-ц від 29.11.2017 до Орджонікідзевського районного суду м. Харкова 
було подану позовну заяву працівником до Державного підприємства «Завод «Електроважмаш» про стягнення середнього заробітку за дні здачі крові для переливання, стягнення середнього заробітку за дні відпочинку за дні здачі крові для переливання, стягнення заробітної плати за дні щорічної додаткової відпустки і стягнення грошової компенсації за завдану моральну шкоду. Позивач зазначив, що порушенням права донора, які містяться в ст.ст. 9, 10, 11 Закону України «Про донорство крові та її компонентів» та трудових прав, визначених у ст. 124 КЗпП України, відповідач завдав йому моральної шкоди, яка виразилася у зіпсованих відносинах з деякими співробітниками, регулярних суперечках з представниками відповідача стосовно неправомірності їх дій. У зв'язку з цим він змушений був докладати додаткових зусиль для організації своєї праці та життя [8].

Суд, заслухавши пояснення учасників судового розгляду, дослідивши обставини справи, а саме: наявні розрахункові листи про виплату заробітної плати позивачу, відсутність заяви щодо надання позивачу додаткових днів відпочинку за довідками щодо здавання крові у повному обсязі, ненадання належних та допустимих доказів щодо спричинення відповідачем моральної шкоди, дійшов висновку про відсутність підстав для задоволення позову [8].

Резюмуючи рішення суду, можна дійти висновку, що необґрунтованість позовних вимог та відсутність необхідних доказів призводить до відхилення позовних вимог судом повною мірою.

Також законодавець окремо виділяє пільги для осіб, які мають статус «Почесного донора України». Зокрема, в статті 13 Закону України «Про донорство крові та її компонентів» представлено такий їх перелік:

- безплатне позачергове зубопротезування;

- пільгове придбання ліків (із знижкою 50 відсотків їх вартості);

- безплатне забезпечення донорською кров'ю та ії̈ препаратами,

- необхідними для їх особистого лікування;

- першочергове придбання за місцем роботи або навчання путівок для санаторно-курортного лікування та першочергове лікування у закладах охорони здоров'я, заснованих на загальнодержавній та комунальній власності;

- позачергове забезпечення у порядку, встановленому Кабінетом Міністрів України, протезами та іншими протезно-ортопедичними виробами;

- використання чергової щорічної оплачуваної відпустки у зручний для них час;

- отримання надбавки до пенсії у розмірі 10 відсотків від затвердженого прожиткового мінімуму на одну особу в розрахунку на місяць;

- отримання пільгових позик для будівництва індивідуального житла відповідно до законодавства [3].
Статус Почесного донора України підтверджується правовстановлюючим документом (посвідченням), що видається особі, яка неодноразово (не менше 40 разів) реалізувала своє право на донорство. Досить цікавою $€$ практика суду щодо встановлення фракту належності правовстановлюючого документу у разі допущення неточності в прізвищі донора. у такому разі особа донора може звернутися до суду в порядку окремого провадження, де суд на підставі наведених доказів може винести ухвалу щодо встановлення фракту належності правовстановлюючого документу. Прикладом такого рішення $є$ Ухвала Артемівського міськрайонного суду Донецької області від 03 квітня 2020 року № 219/1727/20, де заявник, намагаючись оформити надбавку до пенсії, звернувся за консультативною допомогою до Бахмутсько-Лиманського об'єднаного управління Пенсійного Фонду України Донецької області. Однак під час розгляду його документів працівниками управління йому було рекомендовано звернутися до суду, оскільки у них виникли сумніви щодо належності заявнику посвідчення.

На підставі наведених заінтересованою особою доказів суд, розглянувши подані документи та матеріали, всебічно і повно з'ясувавши всі фактичні обставини, на яких ґрунтуються заявлені вимоги, об'єктивно оцінивши докази, які мають юридичне значення для розгляду справи і вирішення справи по суті, доходить висновку, що заявлені вимоги щодо встановлення фракту належності правовстановлюючого документу підлягають задоволенню з огляду на їх законність та обґрунтованість [9].

Зупиняючись на донорстві органів та інших анатомічних матеріалів, а також проаналізувавши спеціальні законодавчі акти, можна помітити, що вітчизняний законодавець певним чином обмежував суб'єктний склад цих правовідносин. Так, у ст. 12 Закону України «Про трансплантацію органів та інших анатомічних матеріалів людини» міститься таке положення: «...взяття гомотрансплантата (за винятком анатомічних матеріалів, здатних до регенерації) у живого донора допускається у випадках, коли реципієнт і донор перебувають у шлюбі або $€$ близькими родичами (батько, мати, син, дочка, дід, баба, онук, онука, брат, сестра, дядько, тітка, племінник, племінниця)...» [10].

Дійсно, переглянувши судову практику минулих років, можна зробити висновок, що численними були звернення громадян щодо встановлення фракту родинних відносин задля реалізації фрізичною особою свого права на донорство. Так, наприклад, у справі № 395/64/18 від 19 лютого 2018 року до Новомиргородського районного суду Кіровоградської області звернувся громадянин із заявою про встановлення факту родинних відносин, в якій заявник вказав, що не може використати своє право на надання допомоги 
своєму двоюрідному брату, а саме бути для нього донором та надати для порятунку одну нирку, оскільки після звернення в лікарню заявнику було роз'яснено, що відповідно до ст. 12 Закону України «Про трансплантацію органів та інших анатомічних матеріалів людині» він не підпадає ні під одну з указаних категорій, тому йому було відмовлено в трансплантації.

Заслухавши пояснення сторін, показання свідків та вивчивши письмові матеріали справи (свідоцтва про народження, свідоцтва про шлюб, де вказано про зміну прізвища), суд дійшов висновку, що заява про встановлення факту родинних відносин підлягає задоволенню [11].

Важливо зауважити, що Закон України «Про трансплантацію органів та інших анатомічних матеріалів людині» втратив чинність та наразі дійсний Закон України «Про застосування трансплантації анатомічних матеріалів людині» [12], який певною мірою розширив права донора та ввів термін так званого «перехресного донорства», тобто обмін органами між живими донорами, які не $є$ рідними.

Ця новація $є$ досить позитивним зрушенням у рефрормуванні вітчизняного законодавства у сфері трансплантації, адже введення такого виду донорства значно розширило суб'єктний склад правовідносин донорства та осіб, які можуть реалізувати вказане вище право.

Загалом варто зауважити, що аналіз юрисдикційної форми захисту права на донорство дає чітке розуміння того, що рішення суду у цивільному судочинстві базуються на основоположних принципах цивільного процесуального права, чільне місце серед яких займає принцип верховенства права.

Необхідно погодитись з поглядами О.С. Ткачук, який, досліджуючи принцип верховенства права, розглядає його «...як стандарт судового правозастосування та як чинник ефективності цивільного судочинства...» [13].

Слушною є думка деяких науковців, що «Україна, подавши заявку на вступ до Ради Європи і ратифікувавши Європейську конвенцію з прав людини, взяла на себе обов'язок визнавати верховенство права, забезпечити права і свободи людини та демократичність устрою в державі і узгодити внутрішнє національне законодавство з європейським...» [14].

Проаналізована судова практика у сфрері донорства ілюструє вільний доступ до правосуддя, відповідний захист донорів, дотримання прав людини та неупередженість суддів під час вирішення зазначеної категорії справ в Україні.

Висновок. Підсумовуючи вищезазначене, можна зробити висновок, що прогрес у галузі медицини спричиняє постійні зміни в суспільному житті та вимагає подальшого дослідження як у науково-теоретичному, так і в практичному аспектах реалізації прав фізичних осіб на донорство як особистого немайнового права.

Реалізація фрізичною особою особистого немайнового права на донорство є досить складним та багатоаспектним процесом, зумовленим особливостями як суб'єктного, так і об'єктного складу. При цьому проведений аналіз судової практики належним чином ілюструє ефективність юрисдикційної форми захисту особистого немайнового права на донорство, яка здійснюється на основі принципу верховенства права.

Але наразі гостро постає необхідність розвитку дієвих механізмів популяризації здійснення фізичною особою свого немайнового права на донорство.

Тому централізована політика держави, що зосередить свою увагу на таких важливих аспектах, як підвищення правової свідомості громадян та їх інформування, підготовка кваліфікованих спеціалістів, створення та поліпшення необхідної нормативно-правової бази, формування організаційних засад служб та відомств, зможуть дати стрімкий поштовх до популяризації здійснення фізичною особою особистого немайнового права на донорство.

\section{Список використаних джерел:}

1. Конституція України: Закон України від 28 червня 1996 р. №254к/96-ВР. Дата оновлення 01.01.2020. URL: https://zakon.rada.gov.ua/laws/show/ 254\%D0\%BA/96\%D0\%B2\%D1\%8024 (дата звернення: 1.05.2020).

2. Цивільний Кодекс України: Закон України від 16 січня 2003 р. №435-IV Дата оновлення:18. 04.2020. URL: https://zakon.rada.gov.ua/laws/show/435-15 (дата звернення: 1.05.2020).

3. Про донорство крові та її компонентів: Закон України від 23 червня 1995 р. № 239/95-ВР Дата оновлення: 28.06.2015. URL: https://zakon.rada.gov.ua/laws/show/239/95-\%D0\%B2\%D1\%80 (дата звернення 1.05.2020).

4. Про інфекційну безпеку донорської крові та іiі компонентів: Наказ МО3 №385 від 01 вересня 2005. URL: https://zakon.rada.gov.ua/laws/show/z0895-05 (дата звернення: 4.05.2020).

5. Постанова Верховного Суду України. від 15 листопада 2018 року №761/24076/15-ц / Єдиний державний реєстр судових рішень. URL: http://reyestr.court.gov.ua/Review/77910974\# (дата звернення: 29.04.2020).

6. Конвенція про захист прав людини і основоположних свобод Конвенцію ратифіковано Законом № 475/ 97-ВР від 17.07.1997 № 995004 / База даних «Законодавство України». ВР України. URL: http://zakon.rada.gov.ua/ laws/show/995_004 (дата звернення 30.04.2020).

7. Кодекс Законів про працю України: Закон України від 10 грудня 1971р № 322-VIII Дата оновлення: 02.04.2020 URL: https://zakon.rada.gov.ua/laws/show/322-08 (дата звернення: 29.04.2020). 
8. Рішення Орджонікідзевського районного суду м. Харкова від 29 листопада 2017 року№ 644/6005/16-ц. Сдиний державний реєстр судових рішень URL: http://reyestr.court.gov.ua/Review/70656526 (дата звернення: 30.04.2020).

9. Ухвала Артемівського міськрайонного суду Донецької області від 03 квітня 2020 року № 219/1727/20 / Єдиний державний реєстр судових рішень. URL: http://reyestr.court.gov.ua/Review/88579593 (дата звернення: 30.04.2020)

10. Про трансплантацію органів та інших анатомічних матеріалів людини: Закон України 17 серпня 1999 р. № 1007-XIV Втрата чинності: 01.01.2019. URL: https://zakon.rada.gov.ua/laws/show/1007-14 (дата звернення: 14.04.2020).

11. Рішення Новомиргородського районного суду Кіровоградської області від 19 лютого 2018 року № 395/64/18/ Єдиний державний реєстр судових рішень. URL: http://reyestr.court.gov.ua/Review/72257442.

12. Про застосування трансплантації анатомічних матеріалів людині: Закону України від 28 лютого 2019 р. № 2427-VIII Дата оновлення: 02.01.2020. URL: https://zakon.rada.gov.ua/laws/show/2427-19 (дата звернення: 1.04.2020).

13. Ткачук О.С. Проблеми реалізації судової влади в цивільному судочинстві : монографія. Харків, 2016. 600с.

14. Дяченко С.В., Сидорчук В.О. Верховенство права: науковий погляд, нормативне закріплення, судова практика. Юридичний бюлетень: наук. журн. / редкол. : О.Г. Предместніков та інш. Одеса, ОДУВС, 2018. Вип. 6 (6). С. 71-77. URL: http://www.lawbulletin.oduvs.od.ua/archive/ 2018/6_2018/13.pdf. (дата звернення: 5.04.2020).

15. Про затвердження Порядку застосування допоміжних репродуктивних технологій в Україні: Наказ МО3 № 787 від 09 вересня 2013 р. Дата оновлення:11.04.2014. URL: https://zakon.rada.gov.ua/laws/show/z1697-13 (дата звернення: 4.05.2020). 
Спєсівцев Д.С.,

кандидат юридичних наук, старший викладач кафедри цивільно-правових дисциплін Східноєвропейського національного університету імені Лесі Українки ORCID: 0000-0001-7337-7907

\section{ОХОРОННІ ВЛАСТИВОСТІ ТЕХНІЧНОÏ ІНВЕНТАРИЗАЦІЇ ОБ'ЄКТІВ НЕРУХОМОГО МАЙНА, РОЗТАШОВАНИХ НА ЗЕМЕЛЬНІЙ ДІЛЯНЦІ}

\section{PROTECTIVE PROPERTIES OF TECHNICAL INVENTORY OF IMMOVABLE PROPERTY PLACED ON THE LAND PLOT}

Стаття містить результати наукового дослідження охоронних властивостей технічної інвентаризації об'єктів нерухомого майна, розташованих на земельній ділянці, та особливостей іiі використання в цивільному обороті нерухомості.

Встановлюється, що первинна технічна інвентаризація нерухомого майна забезпечує охорону переважно суб'єктивних цивільних прав власника відповідної речі та/або особи, яка здійснювала її будівництво. Своєю чергою поточна технічна інвентаризація виступає одним зі способів охорони суб'єктивних цивільних прав третіх осіб, а також інтересів потенційних набувачів прав на відповідну річ.

Автором аналізується роль технічної інвентаризації в юридичних моделях набуття права власності на нерухомість і відношення до неї суспільства. Окрема увага приділяється реформі, проведеній у 2012-2013 роках, та ії наслідкам. Окреслюються ризики надання факультативного характеру поточній технічній інвентаризації, що були предметом жвавих дискусій напередодні реформи, а також їх оцінка $з$ погляду сучасного стану речей.

Обгрунтовується, що коли поточна технічна інвентаризація переважно виявляє незаконні зміни в об'єктах нерухомості, а не забезпечує їх превенцію чи ліквідацію їх наслідків, їі використання як обов'язкового охоронного інструмента є сумнівним. У зв'язку з цим відмова від обов'язковості такого виду інвентаризації є раціональною у разі, коли відсоток незаконних критичних змін в об'єкті нерухомого майна, що дійсно несуть реальну загрозу здоров'ю та життю фізичної особи та/або майну фізичної чи юридичної особи, є вкрай малим.

Визначається, що як перспективний підхід слід розглядати наділення ріелторів правами проводити технічну інвентаризацію об'єктів нерухомості, розташованих на земельних ділянках, в процесі їі підготовки до продажу. Такий підхід поєднує в собі ріелторську послугу та сервіс технічної інвентаризації й ненав' язливо забезпечує високий рівень охорони суб'єктивних цивільних прав та інтересів потенційних учасників відповідного правочину через обов'язковості технічної інвентаризації об'єкта.

Ключові слова: нерухоме майно, речові права, технічна інвентаризація, охорона, виникнення прав, перехід прав.

The article contains the results of scientific research of protective properties of technical inventory of immovable property placed on the land plot as well specificity of its usage in civil circulation of immovable things.

It is defined that the primary technical inventory of immovable property provides mainly the protection of owner's subjective civil rights on appropriate thing and/or of the person constructed it. At the same time actual technical inventory is one of ways of protection the subjective civil rights of third persons and interests of potential acquirers of appropriate thing.

The author analyzes the role of technical inventory in juridical models of acquisition of property rights on immovable property and social opinion regarding this problem. Considerable attention is paid to the reform of $2012-$ 2013 and its consequences. The main risks of giving the optional character to the actual technical inventory that have been an object of discussions before the reform are defined and considered from point of view of modern reality.

It is defined that in conditions when actual technical inventory mainly can reveal the illegal changes in immovable property construct but can't prevent them or provide the liquidation of its consequences usage of it as obligatory protection instrument is questionable. That's why the abolition of obligatory actual inventory is rational when percentage of critical illegal changes in immovable property construct that provide real danger for health and life of a person or for property of a person or legal entity is woefully inadequate.

It is determined that the perspective approach is empowering the realtor with rights to provide technical inventory of immovable property placed on the land plot during preparations for its selling. Such approach combines the realtor's service and service of technical inventory and provides unobtrusively the high level of protection of subjective civil rights and interest of potential participants of appropriate deal owing to obligatory character of technical inventory of immovable property.

Key words: immovable property, proprietary rights, technical inventory, protection, right emergence, transfer of rights. 
Постановка проблеми. В сучасному суспільстві відношення до технічної інвентаризації об'єктів нерухомого майна, розташованих на земельній ділянці, є досить неоднозначним. 3 одного боку, в радянській період ця процедура використовувалась як інструмент державного контролю у сфрері цивільного обороту нерухомого майна, зокрема, в частині дотримання його учасниками державних будівельних норм та правил під час користування нерухомими речами, а також як засіб забезпечення обліку нерухомості, зокрема житлової. Тому історичне коріння відповідного юридичного інструменту надає йому певною мірою рудиментарного забарвлення. Проте, з іншого боку, технічна інвентаризація має яскраво виражені охоронні властивості, у зв'язку з чим ії̈ використання в цивільному обороті здатне створити умови для належного здійснення його учасниками своїх суб'єктивних цивільних прав на нерухоме майно та законних інтересів щодо нього.

Ураховуючи зазначене, вдосконалення сучасних механізмів виникнення, переходу та припинення суб'єктивних цивільних прав на нерухоме майно пов'язується 3 пошуком компромісу між охоронними властивостями технічної інвентаризації об'єктів нерухомого майна, розташованих на земельній ділянці, її ефектом та «обтяженням» відповідного механізму додатковими процедурами, а відтак з оптимізацією відповідних способів охорони суб'єктивних цивільних прав та законних інтересів учасників ринку нерухомого майна.

Аналіз останніх досліджень і публікацій. Проблеми охорони суб'єктивних цивільних прав на нерухоме майно та інтересів щодо нього ставали предметом розгляду таких вчених, як С.С. Алексєєв, І.В. Венедіктова, І.В. Жилінкова, О.C. loфpре, А.В. Коструба, О.О. Красавчиков, О.О. Кот, Н.С. Кузнєцова, Р.А. Майданик, В.В. Надьон, О.О. Отраднова, Я.М. Романюк, І.В. Спасибо-Фатєєва, Р.О. Халфріна, Г.Г. Харченко, С.М. Хорунжий, М.О. Цуріков, Я.М. Шевченко, Р.Б. Шишка, О.Я. Явор, В.Л. Яроцький та інші.

Постановка завдання. Мета статті полягає у визначенні охоронних властивостей технічної інвентаризації об'єктів нерухомого майна, розташованих на земельній ділянці, встановленні сучасної моделі ії використання в цивільному обороті нерухомості, а також можливих альтернатив їй, що можуть стати орієнтиром подальшого розвитку положень чинного цивільного законодавства України.

Основний матеріал дослідження. Проблема технічної інвентаризації об'єктів нерухомого майна, розташованих на земельній ділянці (далі - технічна інвентаризація), мала актуальний характер протягом досить тривалого часу. Загалом необхідно відмітити, що така інвентаризація передбачає здійснення комплексу робіт з обмірювання об'єкта нерухомого майна з визначенням, зокрема, його складу, фрактичної площі та об'єму, технічного стану (ч. 1 ст. 39-3 Закону України «Про регулювання містобудівної діяльності») [1]. Відповідну проблему необхідно розглядати в двох ракурсах: в контексті первинної технічної інвентаризації та в контексті поточної технічної інвентаризації.

Охоронні властивості первинної технічної інвентаризації стосуються суб'єктивних цивільних прав власника відповідного об'єкта нерухомого майна та/або особи, яка здійснювала будівництво відповідної речі. Технічна інвентаризація дозволяє встановити, чи відповідає збудований об'єкт нерухомості запланованій моделі, і якщо ні, то в чому полягають відмінності і який їх характер. Це має важливе значення, зокрема, під час розрахунків між забудовником та власником відповідної речі, адже іноді трапляються випадки, коли площа збудованого об'єкта є більшою або, навпаки, меншою від запланованої. Попри те, що різниця може становити всього декілька квадратних метрів, саме квадратний метр зазвичай виступає базовою одиницею товару під час реалізації механізмів інвестування. У зв'язку з цим відповідні розбіжності визначають кінцеву вартість всього об'єкта.

Крім того, зокрема, коли особа самостійно здійснювала будівництво нерухомості, технічна інвентаризація дозволяє усунути можливі юридичні перепони у здійсненні суб'єктивних цивільних прав на нерухоме майно, що можуть виникнути в майбутньому. Як зазначає М.О. Цуріков, технічна інвентаризація виконує фрункцію встановлення ступеня відповідності формальної частини нерухомості фрізичній $[2$, c. 37]. Іншими словами, технічна інвентаризація слугує засобом забезпечення внесення, зокрема, до Державного реєстру речових прав на нерухоме майно достовірної інфрормації про відповідний об'єкт. Якщо відповідні відомості до цієї інформаційної бази будуть внесені, наприклад, з будівельного паспорта і при цьому буде наявна різниця між фактичною площею об'єкта та відомостями, внесеними до відповідної системи, то згодом у разі виявлення розбіжностей може постати проблема причини їх виникнення. Це своєю чергою може сприяти виникненню перешкод у здійсненні особою свого права власності на відповідну річ.

Своєю чергою поточна інвентаризація об'єкта нерухомого майна виступає одним зі способів охорони суб'єктивних цивільних прав третіх осіб, а також інтересів потенційних набувачів прав на відповідну річ. Зокрема, як зазначається в сучасній юридичній літературі, технічна інвентаризація пов'язується 3 моніторингом, в процесі якого визначається наявність або відсутність проведення реконструкції нерухомого майна, а також встановлення законності її проведення [2, с. 36]. Такий вид технічної інвента- 
ризації дозволяє виявити незаконне втручання в конструкцію об'єкта нерухомого майна, а тому й ризики спричинення таким втручанням шкоди іншим особам. У зв'язку з цим поточна технічна інвентаризація забезпечує в тому числі інтереси потенційних покупців відповідної речі.

Під час існування так званої системи «подвійної реєстрації» (з 2004 по 2013 роки) учасники правовідносин, що складались у сорері цивільного обороту нерухомих речей, розташованих на земельній ділянці, були вимушені після нотаріального посвідчення відповідного правочину та його державної реєстрації звертатись до бюро технічної інвентаризації (далі - БТІ) за державною реєстрацію відповідного речового права, що виникло на підставі такого правочину. Крім того, перед відчуженням відповідної нерухомої речі обов'язковим було звернення до БТІ за отриманням витягу з Реєстру прав власності на нерухоме майно, що було однією з умов посвідчення нотаріусом відповідного правочину.

Таким чином, проведення поточної технічної інвентаризації об'єкта нерухомого майна перед вчиненням особою правочину щодо його відчуження дозволяло виявити зміни характеристик об'єкта нерухомості за певний період часу, в тому числі встановити проведення реконструкції, та у разі здійснення відповідних змін з порушенням вимог законодавства - унеможливити подальше відчуження відповідної речі. В такому разі витяг з Реєстру прав власності на нерухоме майно власнику не видавався, що унеможливлювало нотаріальне посвідчення відповідного правочину нотаріусом.

Попри зазначене, у 2012 році в контексті намічених реформ проблема ролі технічної інвентаризації в механізмі переходу права власності вийшла на перший план. Наскільки виправданою була необхідність проведення технічної інвентаризації перед вчиненням кожного правочину щодо відчуження об'єкта нерухомого майна і яким був обсяг випадків здійснення незаконних змін в об'єктах нерухомості, що виявлялись в процесі проведення їх поточної технічної інвентаризації, від загальної кількості проведення технічного огляду відповідних нерухомих речей? Ці питання мали бути покладені в основу нового підходу до визначення долі технічної інвентаризації в механізмі переходу суб'єктивних цивільних прав на нерухоме майно.

В цьому аспекті необхідно визнати, що загалом існує декілька варіантів «монтажу» технічної інвентаризації об'єкта нерухомого майна в механізм переходу таких прав, однак усі вони $\epsilon$ інтерпретаціями двох базованих моделей: 1) обов'язкова поточна технічна інвентаризація; 2) фракультативна (на розсуд сторін правочину) поточна технічна інвентаризація. Кожна з відповідних моделей має як переваги, так і недоліки, однак основною проблемою залишається проблема оптимізації, тобто отримання максималь- ного охоронного ефекту з мінімальним використанням юридичних засобів.

Як юридичний фрундамент для переосмислення охоронного значення технічної інвентаризації в механізмі переходу права власності на нерухоме майно Україна обрала другу з окреслених моделей. В результаті внесення в кінці 2012 року змін до Інструкції про порядок проведення технічної інвентаризації об'єктів нерухомого майна, затвердженої наказом Державного комітету будівництва, архітектури та житлової політики України від 24 травня 2001 року № 127, зареєстрованим в Міністерстві юстиції України від 10 липня 2001 року за № 582/5773, з якої були виключені положення про необхідність обов'язкового проведення технічної інвентаризації об'єкта нерухомого майна перед зміною його власника [3], а також вступу в силу з 01 січня 2012 року Порядку державної реєстрації прав на нерухоме майно та їх обтяжень, затвердженого постановою Кабінету Міністрів України від 22 червня 2011 року № 703, положення якого не передбачали необхідності подачі технічного паспорту на об'єкт нерухомості для проведення державної реєстрації права власності набувача [4], проведення поточної технічної інвентаризації набуло факультативного характеру. Основними результатами нововведень стали: 1) збереження за БТІ функцій з проведення технічної інвентаризації об'єктів нерухомого майна з одночасним наданням права іiї проведення суб'єктами господарювання, у складі яких працює один або більше відповідальних виконавців окремих видів робіт (послуг), пов'язаних зі створенням об'єктів архітектури, які пройшли професійну атестацію у Мінрегіоні України та отримали кваліфікаційний сертифікат відповідно до ст. 17 Закону України «Про архітектурну діяльність» [3]; 2) обов'язковою залишилась лише первинна технічна інвентаризація об'єкта нерухомого майна, тоді як поточна технічна інвентаризація може проводитись за бажанням учасників відповідних правовідносин.

Запроваджений підхід дозволяє стверджувати, що суб'єкти нормотворення, оцінивши відповідні обставини, дійшли висновку, що виключення технічної інвентаризації з обов'язкових процедур, здійснення яких $є$ необхідним для забезпечення переходу права власності на нерухомість, не впливатиме кардинально на рівень охорони інтересів потенційних набувачів відповідних речей, а також третіх осіб, для яких створюється загроза у зв'язку з незаконним проведенням реконструкції відповідних речей, що може бути виявлено якраз під час проведення поточної технічної інвентаризації нерухомої речі.

В світлі окресленого цікавою $є$ реакція суспільства на відповідні нововведення. Серед учасників правовідносин, що складаються у сорері цивільного обороту нерухомості, відповідний підхід отримав схвалення, зокрема 
і у зв'язку з тим, що новий порядок спрощував процедуру переходу права власності на нерухоме майно. При цьому за учасниками відповідних правовідносин зберігалось право проведення технічної інвентаризації відповідного майна для підвищення рівня охорони їх законних інтересів. Крім того, нововведення дозволяло заощаджувати час і кошти, які не треба витрачати на проведення технічної інвентаризації. 3 іншого боку, профресійні суб'єкти цивільного обороту нерухомості, зокрема нотаріуси та працівники БТІ, висловлювали побоювання, що через зміни в положеннях нормативно-правових актів на ринок нерухомого майна вийдуть незаконно реконструйовані об'єкти, бар'єром для чого виступала обов'язкова поточна технічна інвентаризація.

Водночас сьогодні в контексті окреслених ризиків слід констатувати, що після проходження майже семи років з моменту набуття законної сили відповідними нововведеннями критичних змін в частині рівня охорони суб'єктивних цивільних прав на нерухоме майно та інтересів щодо нього у зв'язку з відмовою від обов'язковості поточної технічної інвентаризації нерухомості не відбулось. Однією з причин цьому виступило те, що технічна інвентаризація переважно виявляла здійснення незаконних змін в об'єкті нерухомого майна, проте не забезпечувала ефективного усунення відповідних ризиків. У зв'язку з цим особа лише не могла продати річ, проте мала можливість надалі користуватись нею. В результаті нововведень частина відповідних змін набула латентного характеру, проте загалом не можна стверджувати, що це сприяло збільшенню або зменшенню відповідних випадків. Ба більше, відповідна проблема віднесена до компетенції органів державного архітектурнобудівельного контролю та нагляду.

Ураховуючи викладене, необхідно визнати, що оптимізація використання технічної інвентаризації як способу охорони суб'єктивних цивільних прав на нерухоме майно та інтересів щодо нього була проведена досить успішно і склала той випадок, коли суспільний запит задовольняється шляхом зменшення бюрократичних процедур без істотного зниження ефективності охоронних інструментів.

Водночас необхідно відмітити і те, що загалом в Україні застосовним є підхід, апробований у скандинавських країнах, проте з огляду на специфріку суспільної думки його необхідно розглядати як перспективний. Зокрема, в Норвегії, як і в багатьох країнах Європи, значне поширення отримали послуги ріелтора, у зв'язку з чим весь ринок нерухомості обслуговується професійними учасниками, і продавці практично не беруть у ньому участь. Під час підготовки об'єкта нерухомого майна до продажу створюється буклет, який містить кольорові ілюстрації інтер'єру та екстер'єру відповідного об'єкта та, за наявності, прилеглої території, а також всю необхідну технічну інформацію про нього, включаючи здійснені зміни. В такому разі ріелтор виступає і як посередник (агент) і певною мірою як інспектор. При цьому складання такого буклету має обов'язків характер, що дозволяє стверджувати про обов'язковість поточної технічної інвентаризації.

У зв'язку з цим відповідний буклет виконує одночасно дві функції - рекламну та інформаційну, і забезпечує надання потенційному покупцю вичерпної інформації про відповідний об'єкт нерухомого майна, юридичні операції щодо нього, зокрема перебування в іпотеці, та фрізичні зміни, яких він зазнав. Проте, враховуючи те, що наразі в нашому суспільстві культура звернення за професійними послугами ріелторів перебуває на стадії фрормування і поширеним залишається підхід, в рамках якого власники нерухомості воліють самостійно продавати відповідні активи, окреслена концепція залишається перспективою для України.

Висновки і перспективи подальших досліджень. Підводячи підсумок, необхідно визнати, що технічна інвентаризація об'єктів нерухомого майна, що розташовані на земельній ділянці, займає важливе місце в юридичних механізмах цивільного обороту нерухомого майна. При цьому ії̈ охоронне значення $€$ досить чітким, незалежно від того, чи має вона первинний або поточний характер.

Проведення технічної інвентаризації відповідного майна одразу після його створення покликане індивідуалізувати нерухому річ шляхом визначення ії̈ складу, фактичної площі та об’єму, технічного стану й таким чином зафріксувати ії характеристики, що є умовою ефективного здійснення її власником своїх правоможностей.

Своєю чергою поточна технічна інвентаризація нерухомості дозволяє визначити відповідні її реальні характеристики в певний момент часу, а також виявити зміни, яких вона зазнала за певний період часу, й покликана забезпечити інтереси потенційного набувача права власності на відповідну річ. В цьому аспекті слід погодитись із тим, що під час купівлі об'єкта нерухомого майна більші ризики несе саме покупець, який є більш зацікавленим у проведенні технічної інвентаризації потенційного об'єкта покупки [5, с. 257]. Проте надання такій інвентаризації необов'язкового характеру не означає позбавлення учасників відповідних правовідносин можливості використати відповідний охоронний юридичний інструмент.

В умовах коли поточна технічна інвентаризація переважно виявляє незаконні зміни в об'єктах нерухомості, а не забезпечує їх превенцію чи ліквідацію їх наслідків, її використання як обов'язкового охоронного інструмента $є$ сумнівним. Крім того, відмова від обов'язковості такого виду інвентаризації є раціональною, коли відсо- 
ток незаконних критичних змін в об'єкті нерухомого майна, що дійсно несуть реальну загрозу здоров'ю та життю фізичної особи та/або майну фізичної чи юридичної особи, є вкрай малим. У зв'язку з цим така відмова є реакцією держави на зменшення випадків здійснення особами незаконних критичних змін в об'єкті нерухомого майна.

Водночас як перспективний підхід слід розглядати наділення ріелторів правами проводити технічну інвентаризацію об'єктів нерухомості, розташованих на земельних ділянках, в процесі її підготовки до продажу. Такий підхід поєднує в собі ріелторську послугу та сервіс технічної інвентаризації й ненав'язливо забезпечує високий рівень охорони суб'єктивних цивільних прав та інтересів потенційних учасників відповідного правочину. Така модель може найбільш повно проявити свій потенціал у разі досягнення відповідного рівня культури продажу нерухомого майна через професійних учасників ринку. Проте для цього потрібен час.

\section{Список використаних джерел:}

1. Про регулювання містобудівної діяльності: Закон України від 17.02 .2011 р. № 3038-VI. Відом. Верхов. Ради України. 2011. № 34. Ст. 343 (із змінами).

2. Цуріков М. О. Роль технічної інвентаризації в обороті нерухомого майна України. Бюл. Мін. юстиціі Украӥни. 2013. № 1 (135). С. 31-38.

3. Про затвердження Інструкції про порядок проведення технічної інвентаризації об'єктів нерухомого майна: наказ Державного комітету будівництва, архітектури та житлової політики України від 24.05.2001р. № 127, зареєстрований в Міністерстві юстиції України від 10.07.2001 р. за № 582/5773 (у редакції наказу Міністерства регіонального розвитку, будівництва та житлово-комунального господарства України від 26.07.2018 р. № 186). Офій. вісн. Украӥни. 2001. № 28. Ст. 1290 (зі змінами).

4. Про затвердження Порядку державної реєстрації прав на нерухоме майно та їх обтяжень і Порядку надання інформації з Державного реєстру речових прав на нерухоме майно: постанова Кабінету Міністрів України від 22.06.2011 p. № 703. Офіü. вісн. Украӥни. 2011. № 51. Ст. 2035 (зі змінами).

5. Спєсівцев Д.С. Нотаріус як спеціальний суб’єкт державної реєстрації речових прав на нерухоме майно та їх обтяжень (нормативно-правова база та лекційні записи). Київ : Українська нотаріальна палата, Ін-т підвищення кваліфікації працівників органів юстиції, 2013. 304 с. 


\section{УДК 340}

DOI https://doi.org/10.37687/2413-6433.2020-1.13

Тимошенко М.O., кандидат юридичних наук, проректор Європейського університету ORCID: 0000-0003-2584-5731

\section{ДО ПИТАННЯ ПРО СОЦІОЛОГО-ПРАВОВИЙ ЗМІСТ ПРИЗНАЧЕННЯ ОСВІТИ}

\section{ON THE QUESTION OF THE SOCIOLOGICAL AND LEGAL CONTENT OF THE PURPOSE OF EDUCATION}

У статті обгрунтовано соціальну сутність та призначення освіти та вищої освіти зокрема у контексті конституційно-правового закріплення права на освіту. Реалізації цього права кореспондує обов'язок держави забезпечувати функціонування мережі освітніх закладів, рівний доступ до освітніх послуг, розвиток законодавства про освіту, формування системи працевлаштування випускників навчальних закладів, створення гарантій використання цього права. Отримання вищої освіти стає найбільш значимою для кожної людини соціальною потребою, задоволення якої сприяє створенню гідних умов життя кожному, справді вільному і всебічному розвиткові людської особистості. Адже саме реалізуючи конституційне право на вищу освіту, людина долучається до процесу набуття знань, умінь, навичок, інформації, до духовно-культурних цінностей людської цивілізації. У статті проаналізовано підходи до розуміння сутності і призначення освіти в українській та зарубіжній літературі. Освіта розглядається як юридична категорія, що позначає правовий інститут, урегульований нормами міжнародного й національного права. Освіта в юридичному вимірі трактується як суспільні відносини, урегульовані нормами права, у яких формується й реалізується державна політика, визначаються стандарти освітньої діяльності, здійснюється адміністрування у сфері освіти, забезпечується якість освіти тощо, а також як сфера реалізації фізичними особами їх прав на освіту. Автор визначає як освіту і сферу функціонування уповноважених державних органів, юридичних осіб публічного права, у межах повноважень яких створюються умови для реалізації суб' єктивних прав на освіту.

На підставі аналізу соціологічних та правових елементів права на вищу освіту, яка в умовах глобалізації соціальних, економічних, культурних та інших процесів у масштабах сучасної цивілізації стає невіддільним складником та зумовлюючим фактором подальшого суспільного прогресу, зроблено висновок про перетворення права на вищу освіту на обов’язковий елемент людської культури 1 цивілізації в сучасних умовах, необхідність надання широкого доступу до вищої освіти представникам різних верств суспільства. Це, зокрема, стало предметом теоретичного осмислення у філософських та соціологічних концепціях Д. Белла, М. Маклюена, О. Тоффлера та інших вчених, згідно з якими вища освіта стає обов'язковою умовою соціалізації особистості, залучення їі до суспільних процесів.

Ключові слова: освіта, вища освіта, конституційне право на освіту, освітні послуги, соціальне призначення права на вищу освіту.

The article substantiates the social essence and purpose of education and higher education, in particular in the context of the constitutional and legal consolidation of the right to education. The realization of this right corresponds to the obligation of the state to ensure the functioning of the network of educational institutions, equal access to educational services, development of legislation on education, formation of the employment system for graduates of educational institutions, creation of guarantees for this right. Since realizing the constitutional right to higher education a person joins the process of acquiring knowledge, skills, information, spiritual and cultural values of human civilization, higher education becomes the most important social need for everyone, the satisfaction of which contributes to creating decent living conditions for everyone, truly free and comprehensive development of the human personality. The article analyzes the approaches to understanding the essence and purpose of education in Ukrainian and foreign literature. Education is seen as a legal category denoting a legal institution governed by international and national law. Education in the legal dimension is interpreted as social relations regulated by law, in which state policy is formed and implemented, standards of educational activities are determined, education is administered, quality of education is ensured, etc., as well as the sphere of realization of their rights to education. The author sees education as the sphere of functioning of authorized state bodies, legal entities of public law, within the powers conditions are created for the realization of subjective rights to education.

Based on the analysis of sociological and legal elements of the right to higher education, which in the context of globalization of social, economic, cultural and other processes in modern civilization becomes an integral part and determinant of further social progress, concluded that the right to higher education element of human culture and civilization in modern conditions, the need to provide wide access to higher education to various segments of society, which has become the subject of theoretical understanding in the philosophical and sociological concepts of D. Bell, M. McLuhan, O. Toffler and other scientists, for which higher education becomes a prerequisite for socialization as a person, his involvement in social processes.

Key words: education, higher education, constitutional right to education, educational services, social purpose of the right to higher education. 
Постановка проблеми. Право на вищу освіту $€$ невіддільним складником конституційного права на освіту. Реалізації цього права кореспондує обов'язок держави забезпечувати функціонування мережі освітніх закладів, рівний доступ до освітніх послуг, розвиток законодавства про освіту, формування системи працевлаштування випускників навчальних закладів, створення гарантій використання цього права.

Аналіз останніх досліджень і публікацій. Питання юридичного змісту суті права на освіту, його конституційного закріплення та реалізації (гарантування), у тому числі у сфері вищої освіти, досліджували такі вчені, як А. Алєксєєв, В. Андрущенко, Д. Белл, В. Боняк, Н. Губерська, В. Журавський, М. Кастельс, Ю. Кириченко, Р. Ковальчук, М. Маклюен, М. Мацькевич, О. Мельничук, М. Де Сальвіа, Р. Стефранчук та інші.

Метою статті $€$ з'ясування соціального призначення освіти загалом та вищої освіти зокрема, відображення цього феномену в українській та зарубіжній юридичній науці.

Виклад основного матеріалу. Модернізація суспільного і державного розвитку на сучасному етапі невіддільна від забезпечення всебічного розвитку особистості. Своєю чергою такий розвиток не уявляється можливим без здобуття особою придатного для функціонування в сучасному суспільстві освітнього рівня, що зумовлює ії активну діяльність 3 реалізації належного їй суб'єктивного права на освіту. Саме в процесі реалізації цього права людина долучається до процесу набуття знань, умінь, навичок, інформації, тобто забезпечується ії̈ доступ до духовно-культурних цінностей людської цивілізації. Такий доступ до цих цінностей є найбільш значимою для кожної людини соціальною потребою, задоволення якої сприяє створенню гідних умов життя кожному, справді вільному і всебічному розвиткові людської особистості [1].

Водночас реалізація такого права передбачає організацію та функціонування мережі навчальних закладів, покликаних надавати особі освітні послуги на всіх рівнях і етапах освіти. Процес надання таких послуг своєю чергою повинен мати об'єктивний, науково зумовлений, планомірний характер - від нижчого (дошкільна освіта) до вищого (вища освіта) рівня.

Суб'єктивному праву особи на освіту кореспондує обов'язок держави надати хоча б мінімальні гарантії задля забезпечення доступності освітніх послуг у межах фрункціонування відповідної мережі навчальних закладів. Відтак реалізація права особи на освіту передбачає синтез діяльності мережі навчальних закладів різних форм власності із діяльністю самої держави, що має забезпечувальний та управлінський характер. Така державна діяльність має багатоплановий характер в освітній галузі, але насамперед вона стосується як «позитивізації» права особи на вищу освіту, так і легітимації (закріплення) організаційно-правових засад реалізації згаданого права.

Комплексне наукове дослідження сфери правового регулювання діяльності закладів вищої освіти неможливе поза контекстом цільової та функціональної спрямованості такої діяльності, скерованої, зокрема, на реалізацію державної освітньої політики, покликаної сприяти всебічній реалізації права людини на освіту. При цьому визначальною $€$ нормативно-правова модель регулювання освітніх відносин, встановлена на конституційному рівні. Така модель формується саме на найвищому рівні нормативного опосередкування - на рівні відповідних конституційних норм, що мають взаємопов'язаний характер і загалом «програмують» модель комплексного правового регулювання суспільних відносин у сорері вищої освіти. Конституційне регулювання питань вищої освіти та відповідне програмування правового закріплення цієї сфрери суспільних відносин є об'єктивним відображенням загальносуспільного значення та функціональних властивостей феномену вищої освіти для розвитку особистості, суспільства і держави, втіленням суспільної цінності зазначеного феномену в сучасних умовах розвитку глобалізованої цивілізації.

Відтак ключове значення в конституюванні вихідних засад правового регулювання господарської діяльності закладів вищої освіти має саме конституційно-правове закріплення права на освіту та форм його здійснення через діяльність закладів вищої освіти як організаційної ланки, покликаної сприяти реалізації права людини на вищу освіту як елемента суб'єктивного права на освіту взагалі.

Формулювання та реалізація відповідної конституційної моделі освітніх відносин закономірно передбачає врахування базових системних закономірностей у сфері вищої освіти, особливо актуальних і значимих у сучасних умовах. Зокрема, в умовах розвитку сучасної цивілізації стає дедалі очевиднішим, що без освіти людина вже не може бути конституйована як повноцінна дієздатна особистість, наділена різноманітними креативними властивостями, особистість, здатна не лише акумулювати накопичений попереднім розвитком суспільства культурний досвід, але й критично його переосмислювати й засвоювати, а також свідомо перетворювати у процесі своєї діяльності оточуюче середовище, змінювати себе, суспільство і світ загалом. У цьому сенсі, як ніколи раніше, нині актуальною $€$ загальновідома сентенція уславленого англійського мислителя Ф. Бекона: «Знання - сила». А ось відомий американський політичний і державний діяч, третій президент США Т. Джефрерсон стверджував, що коли народ $€$ недостатньо освіченим для здійснення своєї влади з повною відповідальністю, слід не поз- 
бавляти його влади, а наділяти шляхом надання освіти [2].

За твердженням сучасних учених та філософрів, «освіта стає стратегічним ресурсом соціально-економічного і культурного розвитку суспільства, поліпшення добробуту людей, забезпечення національних інтересів, зміцнення авторитету і конкурентоспроможності держави в міжнародному просторі» [3; 4]. Одночасно вона «сприяє економічному, соціальному, культурному функціонуванню й удосконаленню суспільства за допомогою спеціально організованої цілеспрямованої соціалізації та інкуль- турації окремих індивідів, вираженій у системі, що містить освітні установи, органи управління ними, освітні стандарти, які забезпечують їх фрункціонування і розвиток» [3]. Нехтування взаємовпливів освітнього та економічного процесів може призводити до падіння інституційної спроможності як освітньої, так і економічної сфрер розвитку суспільства [5].

Висновки. На науковому рівні найбільш переконливими є концепції, що узагальнюють соціологічні та юридичні аспекти френомену освіти, що 3 достатнім рівнем переконливості можуть бути екстрапольовані і до сфрери вищої освіти.

\section{Список використаних джерел:}

1. Резванова Л.А. Сущность социального государства и ее проявление в сфере образования : автореф. дисс. ... канд. юрид. наук. Специальность 12.00.01 - Теория и история права и государства ; История правовых учений ; Науч. рук. Д. Ю. Шапсугов. Ростов-на-Дону, 2004. 22 с.

2. Ладиченко В. Проблеми та перспективи сучасної вищої юридичної освіти. Юридична Украӥна. 2011. № 2. С. 7.

3. Губерська Н.Л. Адміністративні процедури у сфері вищої освіти : дис. ... докт. юрид. наук. Спеціальність 12.00.07 - адміністративне право і процес; фінансове право; інформаційне право ; Київський національний університет імені Тараса Шевченка. Київ, 2015. С. 4.

4. Лисенко М.В. Інноваційна парадигма вищої освіти україни за умов переходу до інформаційного суспільства : автореф. дис. ... канд.. філос.. наук. Спеціальність 09.00.10 - Філософія освіти ; Національний технічний університет України «Київський політехнічний інститут». Київ, 2013. С. 6.

5. Топузов М.Л. Організаційно-економічний механізм інформатизації вищої освіти : дис. ... канд. екон. наук. Спеціальність 08.00.03 - економіка та управління національним господарством ; ВНЗ «Університет економіки та права «КРОК». Київ, 2016. С. 10. 


\title{
СОЦІОЛОГІЯ ПРАВА
}

\author{
науково-практичний журнал
}

\section{Випуск 1 (32)}

Коректура - Н.С. Іанатова

Комп'ютерна верстка - Н.С. Кузнєцова

Формат 60x84/8. Гарнітура Arial.

Папір офсет. Цифровий друк. Ум.-друк. арк. 9,77.

Замов. № 1020/266. Наклад 300 прим.

Видавничий дім «Гельветика»

03150, м. Київ, вул. Велика Васильківська 74, оф. 7

Телефон +38 (048) 70938 69, +38 (095) 93448 28, +38 (097) 7230608

E-mail: mailbox@helvetica.com.ua

Свідоцтво суб'єкта видавничої справи

ДК № 6424 від 04.10.2018 р. 


\section{SOCIOLOGY OF LAW}

scientific and practical journal

\section{Issue 1 (32)}

Proofreading - N.S. Ihnatova

Desktop publishing - N.S. Kuznetsova

Format $60 \times 84 / 8$. Arial Font.

Offset. Digital printing. Conventional printed sheet 9,77.

Order № 1020/266. Edition of 300 copies.

Publishing House "Helvetica"

03150, Kyiv, 74 Velyka Vasylkivska str., office 7

Phone +38 (048) 70938 69, +38 (095) 93448 28, +38 (097) 7230608

E-mail: mailbox@helvetica.com.ua

Certificate of publishing entity

ДК № 6424 as of 04.10.2018 